University of Louisville

ThinkIR: The University of Louisville's Institutional Repository

Electronic Theses and Dissertations

1942

\title{
Waldo Frank's treatment of women.
}

Mary Hodge Cox

University of Louisville

Follow this and additional works at: https://ir.library.louisville.edu/etd

Part of the English Language and Literature Commons

\section{Recommended Citation}

Cox, Mary Hodge, "Waldo Frank's treatment of women." (1942). Electronic Theses and Dissertations. Paper 1691.

https://doi.org/10.18297/etd/1691

This Master's Thesis is brought to you for free and open access by ThinkIR: The University of Louisville's Institutional Repository. It has been accepted for inclusion in Electronic Theses and Dissertations by an authorized administrator of ThinkIR: The University of Louisville's Institutional Repository. This title appears here courtesy of the author, who has retained all other copyrights. For more information, please contact thinkir@louisville.edu. 
UNIVERSIT.Y OF, LOUISVILLE

WALDO FRANK'S TREATMENT OF WOMEN

\author{
A Dissertation \\ Submitted to the Faculty \\ of the Graduate School of the University of Louisville \\ In Partial Fulfillment of the \\ Requiremente for the Degree \\ of Master of Arts \\ Department of English \\ By \\ Mary Hodge Cox
}

1942 
NAME OF STUDENT:

TITLE OF THESIS: Waldo Frank's Treatment of Women

APPROVED BY READING COMMITTEE COMPOSED OF THE FOLLOWING MEMBERS:

NAME OF DIRECTOR:

DATE: May $15,9+2$ 
TABLE OF CONTENTS

PART I

CHAPTYR

PAGE

INTRODUCTION • • • • • . . . . . . .

I. WALDO FRANK'S LIFE AND IITERARY CAREER • • .

II. WALDO FRANK'S IDEAS ABOUT SOCIETY AND ABOUT WOMEN . . . . . . . . . . . . .

III. THE IOVELS AND THEIR THEMES • • • . • . • • $\quad 47$

PART II

I. MODERN WOLEN IN RELATION TO SEX . . . . • •

II. TEE TREATMENT OF WOHEN IN RELATION TO MARRIAGE 99

II. MOTHERHOOD AND YOUNG GIRLHOOD . . . . . . . 147

IV. CONCLUSIONS . . . . . . . . . . . 186

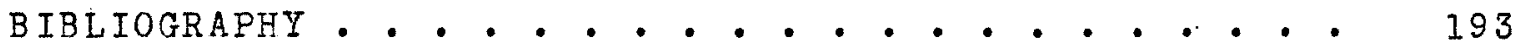




\section{INTRODUCTION}

Originally, I had planned to write a thesis on the portrayal of modern women in contemporary fiction, and, for that purpose, I read and studied many of the novels, written since 1900 , that contain a thoughtful and coreful presentation of women and her problems during these forty years of changing sociel conditions. I then chose ten writers who I thought had mode a genuine contribution to the analysis of modern women, and I began a more intensive study of their books. This led, ultimetely, to my decision to confine my research to waldo Frank, because his portrayal of women seemed more penetrating and comprehensive than that of any of the other writers whose works I had contemplated. The explanation for this lies in the fact that his fictional treatment rests on his careful reflection upon the problems of woman as well os on a definite philosophy of man and society.

Due to the fact that he has written his fiction at fairly regular intervals since 1917, he has been able to manifest a prowing recognition of the changes in the position of women since that date. He himself has been constantly and vitally alive to the rorld about him, and we heve the added advantage, therefore, of seeing his 
vision expand in ever-widening circles of perception. Limited to Waldo Frank, the problem for my thesis beceme two-fold:

1. An analysis of the background of Hr. Frank's fictional treatment of women.

2. An analysis of the fictional treatment itself. These constitute, accordingly, the two parts of my thesis.

The materials which I have used in making these analyses are his novels and essays and the biographical data which have been published and that which were kindly furnished me by the author both by correspondence and in an interview. 
PART I.

CHAPTER I.

WALDO FRANK'S LIFE AND LITERARY CAREER 
PART I.

CHAPTER I.

\section{WALDO FRANK'S LIFE AND LITBRARY CAREER}

An adequate understanding of Waldo Frank's treatment of women requires a three-fold background:

1. A knowledge of his 1 ife and literary career.

2. A knowledge of his ideas as stated in non-fictional form.

3. A knowledge of his novels and the place given to the problems of women in them.

Part I of this thesis contains an analysis of this material, a chapter being devoted to each of the above-mentioned requirements.

chapter I must not be construed as an attempt to write a biography of Mr. Frank, for I feel that the time is not yet ripe for that kind of work. Such a colorful, creative person, still in the prime of life and still intensely in love with life, will no doubt bring forth other worthy productions, end these very experiences of his which I record vill culminate in still greater literary achievements.

Most of the biographical meterial used in this chapter was obtained from Mr. Frank himself. An interview with him in chic8go on January 10, 1942, together with facts which he has written me, gave me tho desired information.

In his literary productions, Waldo Frank has always 
been concerned chiefly with artistic development, social problems, mysticism as expressed in cosmic consciousness, and in the integreted person hoving sense of the Divine. All of his works exhibit these major interests, the emphasis being placed first on one and then on enother during the different periods of his writing career. The chart below gives some indicstion of the shifting emphases as related to his works.

Dete Fiction Non-Fiction Unwelcome lian

$1917-1920$ Dark Hother
Art of $\frac{\text { the }}{\text { Coloux }}$ ier

Our Americe
Major Characteristics

Apprenticeship. Shows interest in art, social problems, mysticism, and search by individuals for integration.
Rahob

$1920-1926$

City BIock

HoI iday

Chelk Face
Virgin spein

Salvos

Time-Exposures
Art Conscjousness

Chief interest is in sesthetic presentation. Concern for social problems, mysticism, and integration are present. Socialism vs. aestheticism. $\frac{\text { New Year's }}{\text { Eve }} \quad \frac{\text { Re-Discovery }}{\text { America }}$

1926-1935 Death ond America

Birth of

Dovid Harkand
Hispena

Dawn in Russia

\section{Social Consciousness}

Balance between mysticism and socialis $\mathrm{m}$.

Sesrch by individuals for integration.

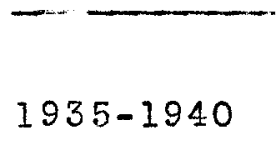

Bridegroom Cometh

$\frac{\text { Summer Never }}{\text { Ends }}$
In the American Jungle

Chart for Rough Water
Cosmic Consciousness Fusion of the integrat. ed person having a sens of the Divine with cosmic consciousness. 


\section{His Apprenticeship}

Actually, Waldo Frank's literary cereer begen about tho yeer 1893, when, as a very precocious lad of four, he wrote his first play. Having been born into on upper middle class family, his creative ability, thus osserting itself early, was given every opportunity for development. His liberal, metropolitan bockground and his adventages, culturally, socially, and educationally, prepared him for the full flowering of his fertile mind. He wes of mixed Northern and Southern parentage, his father being a New York lawyer who was quite interested in social reforms and his mother a gifted and talented musician from Alabama. His deep mysticism and his abiding faith in God are the traditional characteristics of his Jewish ancestors. His perents guided his early training wisely and rell, and a novel which he wrote when he was eixteen wes withheld from publication by his father, although the lad had already found a publisher who wished to undertake the publicstion of the book. Indications of the broad educational training he was to receive and the cosmopolitan outlook he wos to acquire from traveling widely, studying in many countries, and becoming intimetely acqueinted with men ond women in all walks and conditions of life were manifested early. The year 1906 was spent by Waldo Frank studying in Lausanne, Switzerland; he ranched in Wyoming for two yeors, 1911-13; then there followed another year abroad, spent chiefly in Paris and 
Germany; bock in New York, he left the comforts and luxuries of his own home and lived for the next twelve months on an East side block similar to the one which he used es his setting for City Biock. In 1917, he traveled to the southwest, and he says, "That first experience with the Hispanic and the Indian were to have a lasting effect on my life work." In the meantime, he had finished the grammer and high school courses in the public schools of New York, had graduated from Yale in 1911, and had done some journalistic Writing. He was dramatic critic for the New Haven Journal Courier during his last years at Igle; he wrote for the New York Evening Post and Times while in Wyoming; and for the next two years he was a free lance writer, trying his hand at several different types of creative work.

Such was the liberal background and the educational training which produced Waldo Frenk, already known as a rebel and as a young writer who not only forsook the besten and conventional paths, but who even dared to blaze new trails of his own. Several plays which he wrote during this time were termed "too unconventionel" for production or publication. Having been financially independent of publisher's opinions and people's tastes, he was able to develop his own idess and plans in his literery career.

He founded the Seven Arts Magazine in November, 1916 , with James oppenheim. It was a megazine dedicated to the a.rts in Americe and designed to give young writers the 
opportunity to publish their works. Mr. Frank, as its associate editor, must be given a large share of the credit for the aesthetic tone of the magazine and its great value as a forerunner of many similar ones which were to appear later. In it were published several orticles and editorials written by him that set forth his views on American life and its artists. These were to be crystallized at a later period into his firm beliafs and used as basic themes for his novels and essays.

The novels, The Unwelcome Man and Dark Mother, written during this period, indicate his tendency toward a frank and constructive criticism of social conditions; the rebel of Yale records graphically the rebellions of individuals against the mores of society. The psychological studies which he made of his cheracters are penetrating, showing already a tendency to delve deeply into the actions of people.

In December, 1916, he married Margaret Naumberg, the founder of the Walden School in Ney York City and a pioneer in applying psychoanalysis in education. Although they were divorced in 1925, one finds several references in his later novels, The Death and Birth of David Harkand and The Bridegroom Cometh, to the sort of educational work and the type of school which Miss Naumberg sponsored. Alma Magoon, his second wife, whom he married in 1926, was probably more interested in social conditions and labor movements than had been his first wife, for she came from the industrial 
town of Manchester, New Hampshire, and gave Mr. Frank much of the factual material which he used in depicting the town of Marling in The Bridegroom Cometh.

It is from his mother, more than likely, that Waldo Frank inherited his love for music and art, and this innate interest in the aesthetic, cultural things of life would naturally be cultivated and trained by perents such as his were; such tastes and tondencies were developed and intensified by his years of travel in places where the art and music of the people are such an integral pert of their life. His next published work, as well as the next period in his writing career, is due in a lerge part to his love of the aesthetic. While he was in Paris, he had met certain members of the Theatre du Vieux Colombier and had become friends with the director, Jaques Copeau. When this production was brought to New York, Mr. Frank wrote a literary criticism in which he relates faithfully and graphically the history of the Vieux Colombier from its beginning in France to the time of its sojourn in New York. The appearance of this book is important because it presages that period in Waldo Frank's writing when the outstanding characteristic is his art consciousness.

His determination to think things out for himself and to form his own conclusions regardless of the opinions of others is well demonstrated in his refusal to fight during the First World War. Being an American socialist who was 
convinced we should stay out of the war, he registered, not as a pacifist or as a conscientious objector against war, as so many accounts have said, but as an objector to that particular war. He wrote me that he is still proud of his decision; that Dark Mother was written in 1920 while waiting to go to prison because of his refusal to fight. He concluded:

"In order to make sure that unconsciously my objections pere not due to fear, I imaginatively stood myself up before a firing squad day fter day for a whole winter; feeling that I should be willing to die for my refusal."

By the next year, he was clearer in mind and happier, and Our America was written. Many of his ideas and much of his factual material for this book came from his travels in the southrest. In it, he gives a painfully accurate description of the state of America and whet he calls the American reality. It was the first of his books to be translated into French.

The period of apprenticeship logically closes with the appearance of Our America, for soon efter this he went abroad, and, when his next books appear, one finds certain other characteristics emphesized which were not so evident in the apprenticeship period. Those ideas which serve to differentiate him from all other modern writers are present, even in the experimental period, but it is as though the author were sherpening his tools for the finely chiseled work of subsequent years. 


\section{Art Consciousness}

The aesthetic is outstandingly predominant in his works of this second poriod, reaching its peak in Virgin Spain, book published in 1926. Being a history of the cultures, religions, and influences that hove produced the Spain of today, it is truly a work of art in its presenta-

tion. As the author describes the scenes of this country, its peoples, customs, amusements, religions, music, and art, it is as if one were beholding, one after another, great paintings depicting these things. This book was the result of his first trip to Portugal and spain in 1921. of spain he says," I fell in love with that country. I had commitments to write popular articles to pay my journey. Instead, loving spain, I spent several years studying her, reading her great literature, revisiting her in 1824, and the result was Virgin Spain."

He finished Rahab in Paris in the summer of 1921, having written on it during his travels in the United states and at odd times since 1915. City Block, which had been written at various times simultaneously with Rahab, was published while he was living in Dorien in 1922.

The material for Holiday, which was written while he was living at Darien and published in 1923, was secured while Mr. Frank was on a walking tour of the South with one of his friends. He liked the Southern negroes with whom he came in contact as they journeyed from one farm to another. 
Often their meals were given to them by some family of fine, friendly negroes. They visited their churches, and the description of the negro revival meeting in Holiday is his impression of these church services which he attended. One night, at a "protracted" revival, the preacher asked both of these young men to sperk. Waldo Frank was quite impressed by their sincerity and goodness, and he wanted to tell them so. He spoke to them at length, and they listened so attentively that he was sure they appreciated what he had said. As they walked home, his friend was strangely silent about Waldo's speech, snd finally the latter asked him what he thought about it.

"It was all right," was the unenthusiastic answer.

"We11," retorted Mr. Frank, "the congregation seemed to like it, at any rate. They listened very attentively." "Oh, yes," was the rejoinder, "they were impressed beceuse they had no idea what you were talking about." Rahab, Holiday and City Block are aesthetic creations. Frank's mysticism, his use of symbolic material, and his religious fervor have full sway in these three books, and it is here that we find his expressionistic writing at its best. In several instances, the author resorts to sheer poetry for his expression of intense emotion. The musical cadences rise in rhythmic motions clear and free. Beautiful figures of speech, lyrical crystallizations, and breathtakingly poignant scenes are the chief characteristics. 
The flame and color of his myths and symbols are artistically poetic and are used to present various moods and depths of feeling. They are arranged with pauses, like rests in music, drawing out of the characters their inmost thoughts in lyrical form. Beach traces his futuristic manner to German influences, perticularly "the influence of postimpressionistic painting and sculpture." 1

Chalk Face, a novel which the author terms a "mystery" story, was published in 1924. Mysticism and symbolic figures, together with its clear aesthetic treatment, are the links that bind it with this period. It was at this time, also, that Salvos appeared. The latter is a collection of essays which Mr. Frank wrote at various times on the arts... the theater, ploys, poets, novelists, and the American scene in general.

The books written during this period carry, deoply embedded in their artistic presentation, sharp criticisms of existing conditions. Contending forces seemed vying for prominence... socialism versus aestheticism. His manner of portraying prostitution in Rahab is an eloquent plea for a deeper, more humane treatment and understanding of those women who, for the most part, have been forced into this type of life by the evils and inequalities in our own society; Holiday is ory against race prejudice and an urging for 
greater Christian tolerance toward the negro; City Block contains the rorking out of many of his theories regarding modern society of today.

The works of this period remind me in some respects of the man Mr. Frank is today. One notes just a touch of imperiousness and pride flashing through the genuine humblenoss and gentleness of the man himself; the unusual kindness and the understanding which he has for the ordinary, common people are mixed with the barest manifestation of that heritage which is his from high-born, gently-bred ancestors; his love for humenity and his ability to discount the errors and mistakes of his fellowmen are the outgrowths of that development of himself end thet broadening process through which he has put himself which give him the right to scorn the insincere and to be intolerent of those who are untrue to themselves. These very contredictions are evident in the works of this period. He brings to us the problems of the lowly and the oppressed; their lives, no matter how sordid, are dest with kindly and understendingly; yet the stories of these very humble people are presented in the most artistic menner possible.

As he himself traveled and observed keenly human life in many places, he incorporated that wider, broader view into his novels. The aesthetic form was his, but expanding sympathies and ideas must find expression, and the works of the next period take on a deeper significance. 


\section{Period of Sociel Consciousness}

Because of this growing concern in social conditions and in the lives of people everywhere, especielly in the United Stotes, his social consciousness takes precedence during this period over every other characteristic and interest. He seems to have struck a balance between mysticism and socielism, evident in his writings from 1926 to the publication of The Death and Birth of David Markand in 1935 .

In 1926, he traveled in France, Egypt, Palestine, and settled in the Ile d'Oleron off the coast of France near Bordeaux. There he wrote 50,000 words of the first draft of David Markand ... and tore it up. Mr. Frank himself telis of the next happenings:

When I returned to the United States, I wos asked by both Croly of the New Republic and by the editor of the Saturday Evening Post to do a series of articles on American life. I turned down the Saturday Evening Post offer, which would here meant a fortune but a diluted job, and accepted the New Republic offer, although it meant giving up Markand.

The articles which appeared in the Ner Republic formed the nucleus for Re-Discovery of America, published in 1929. It is a criticism of Americen life ond culture, with an analysis of our European background, and an offering of a plan for our emerging from the "American jungle" in which we find ourselves. This book is anglyzed in the second part of this chapter.

At the end of that year he returned to the writing of 
David Markand, only to get an invitation from Mexico and Argentina to lecture. He was weoks in arriving at his decision to postpone the book again and accept this offer.

This was a triumphal journey, recorded in Waldo Frank in Americe Hispana, published by the Instituto de las Espans of Columbia University. He was most enthusiastically received by the sereral South American countries he visited and was even lent a government aeroplane in which to travel. In Buenos Aires he became a popular figure. The subjests he discussed appealed to the intellecturl tastes of the Argentines, and he attracted large audiences. He was the first envoy to Buenos Aires of the ArgentineNorth American Cultural Institute.

When he returned, he wrote America Hispana (1931); and he then edited book called Toles from the Argentine (1930), containing seren stories by the most important writiers of that country. This was the first of a series of Spenish translations.

His play, New Year's Eve, was published in 1929. Mir. Frank observed at the time of publication that no work of his had been so long in the process of creation. The theme came to him in 1914; he tried to write it in 1919 and again in 1923 but failed to find scenaric frame and form thet suited his subject. It was written in 1925 , revised in 1927 , and again in 1929 .

After the writing of America Hispana and the death of 
his father, he felt that he needed a vacation. He chose Norway, as he says, "to get the tang of the tropics out of my eyes". He could not resist going to Russia, however, instead of Norway, and Dawn in Russia was written in one month on his return. It was published in 1932.

Then, he returned to The Death and Birth of David Markand, but he says "there were six months of painful trensition before I could return to the mood of the novel. When it ceme to the finel chapters, I retreated from New York to Argentine to write them: a friend lent me a house near Buenos Airos, another lent me a ranch in Patagonia, and there I finished the book." 1

The Deoth and Birth of David Narkond was written, therefore, during the time Hr. Frank wos studying the peoples of many countries, living with them, and evaluating criticaliy their problems and their ways of living ... and it was completed after the full. weight of his conclusions had been formed. He had studied labor conditions in Kansas in 1919-20 when he worked for many months with the NonPartisan League of thet state; he had seen the results of the new regime in Russia when he traveled there; labor conditions in spain were familiar to him, and the socialistCommunist-Peoples Front struggle was being waged hotly in France at the time he was living there. These experiences. prepared him well for the factual material on workers' organizations and labor movements which are presented in 
David Markand.

Current Biogrephy for 1940 adds this information on his beliefs pertaining to the labor organizations and morements:

After the First World War, Frank veered sharply to the Left. He was forced slowly but surely into the arms of radicalism though "he did not surrender without a protracted inner struggle". He accepted the doctrine of class struggle and the ends proposed by Marxism - "the establishment of collective society" but never in orthodox Harxist form.

The Death and Birth of David Markand and The Bridegroom cometh de veloped the theme the "only swift maturity of a mass party of revolutionery Communism, manned by Labor and by enlightened guards of petty bourgeoisie and intelligentsia, can destroy American Fascism by destroying capitolist system before it has time to enter the last period of paroxysm, euphorio and catalepsy." Frank, however, was no communist, and at the time of the Trotsky trials had definitely broken with them.

At the outbreak of World War II, Frank believed thet "with every ounce of our economy, of our political prestige, we should make ourselves non-belligerent alijes of the Allies." It ras because he felt this belief was not shered clearly enough by the New Republic that he resigned from the megazine in May 1940. This created quite a stir, for he had been a consistent contributor to the magaine and long a member of the staff.l

The Death and Birth of David Markand is the result of years of thought and work; it contains some of his most meture and deeply rooted opinions on conditions in our country and the state of society as it exists today. The period following, beginning as it does with the publication 1. Frank, Waldo, Current $\frac{\text { Biography }}{\text { H. W. Wir }} \frac{\text { for Co. }}{\text { D. }} \frac{1940}{312}$, (New York, 
of The Bridegroom Cometh, shows more smoothness in presentation and more mellowness in incorporating his opinions into fictional form, but he still mointains his interest in social conditions.

\section{Period of Cosmic Consciousness}

The fusion of mysticism and socialism into cosmic consciousness, out of which emerges the integrated person hoving a sense of the divine in him, is the outstanding characteristic of the writings of this period. There is a great difference between the individual and the person, and The Bridegroom Cometh and Summer Never Ends sre concerned primarily with the portrayal of the individual striving to become a true person.

Waldo Frank explains in Chart for Rough Water the difference between these two terms.

The individual was born with socrates; before that time, the integer of consciousness was the group. Analytic thought separated the individual from the group and from nature, and concepts and ideas established his command over the world about him. Platonic Universals fortified the position of his ego end endowed him with the ides of individual immortality. An individurl, however, is incomplete and chrotic unless something else is added. Without the integration of the divine into his life, he is a breeder of chaos.

An individual is made whole and true and becomes 
a person if he pertakes of the divine. Then an individual knows that his life has purpose and direction because God is in him, he is then a person. To use his exact definition: "The individual integrated in his cosmos, I cell the person."I Mary Donald in The Bridegroom Cometh is the author's person; she is the well-integrated being who incorporates a belief in the Divine into her life. Danye Petersen in Summer Never Ends is a fine example of the individual. The chief cheracteristic of these books that place them definitely in this period is the keen analysis of each character with emphasis upon the place they occupy in the social structure of our civilization. Chart for Rough Water, published in 1840, contains Faldo Frank's own conception of how our netion perticularly happened to be in the condition in which it found itself in 1940, and his suggestions for getting on solid ground again. It is a frank and clear-cut treatment of social conditions; much spece is devoted to a study of our becoming integrated into a society of persons, all believing in and admitting into our lives the Divine element. Mr. Frank was before the war, American correspondent for La Nouvelle Revue Francaise and for Europe, both Parisian publicotions. He is a lecturer at the Nen School for Social Research, New York City. At the present time,

1. Frank, Waldo, $\frac{\text { Chart }}{\text { Doran }} \frac{\text { for }}{\text { and }} \frac{\text { Rough Weter }}{\text { Co., } 1940) \text { p. } 127}$ Fork: Doubleday, 
a. Ithough he is busily engaged in writing a novel and working out the general plans for still another one, he is on his way to South Americe to lecture in several universities ond cultural centers in Brazil, Uruguay, Argentina, and Chile. These last activities, going on as they are even as I write this, will substantiate my statement in the beginning of this chopter that the time is not yet ripe for a biography; that more works may be expected from Mr. Frank which will add to his contributions in the field of literature and history. Whatever he produces in the future will be filled with the sincere purpose which dominates his Iife and with the clear convictions which guide him in forming 811 his conclusions. 
PART I

CHAPTER II

WALDO FRANK'S IDEAS ABOUT SOCIDTY AND ABOUT WOMEN 
PART I

CHAPTER II

\section{WALDO FRANK'S IDEAS ABOUT SOCIETY AND ABOUT WOHEN}

This chepter is devoted to an analysis of Waldo Frank's fundamental ideas about modern society and the social structure of our own country. He has published four books which set forth his beliefs and conclusions and in which he points the way out of our "American Jungle", as he calls our present-day habitat. These books are: Our America (1919); Re-Discovery of America (1929); America Hispana. (1931); Chart for Rough Water (1940). These are the sources for the material which I shall use. In addition to these books, I shall use quotations from Dawn in Russia (1932), for the author makes some comparisons and contrasts between customs in our country and Russia which set forth his own ideas very clearlye

This chapter is divided into two sections: A treats of his beliefs concerning modern society in general; $B$ is devoted exclusively to his tenets regarding modern American women. I have made this division, thus separating his ideas regarding women from the rest of the meterial because, since I am making a study of Mr. Frank's treatment of women, I should like to emphasize his fundamental beliefs relative to them. 
A

\section{HIS IDEAS ABOUT SOCIETY}

Since Mr. Frank is one of the few present day novelists who have formuleted and crystallized into words ideas and conclusions about our modern society and then have created novels and characters which embody these fundamental beliefs, it is obvious that one must understend thoroughly his principles and opinions in order to make a clear analysis of his literary creations. This section, then, is a diagnosis of this material. His ideas in regard to society are grouped according to the plan he employs in chart for Rough Water:

(1) The Present state of Our Society

(2) What Has Happened

(3) What Can Be Done About It

The Present State of Society

An analysis of his theory of chaos is this:

A state of chros completely dominates the social structure of the United States today. It dwells in the hearts and souls of our millions of people, end we have generated and nourished and disseminated profusely its poisonous rays until our nation is enveloped in its fumes. Mr. Frank's theory of chaos is:

Selfhood is falsehood, unless it is experienced as a relative focus in the unity of a.l men and all being. The usual "self" is a flashing and fusing of moods, a flux of memories and behaviours split from the unity of life. Its "separatenes" is its deletion of the whole that makes it. Such "self" is the root of all diseses; multiply it and it 
is the modern chaos. 1

Since the beginning of the trentieth century, the American man has been the most lonely creature in the world; he is an inhabitant of the great American jungle - - a savage,

possibly bright and enterprising, who by no concepts transcending the immediate needs of sense have made this nature theirs; men who have not learned to assimilate their world together with their personal desires into some kind of Whole. The jungle can but perpetuate itself through cegseless proiferation of chaotic power.

He elucidates this:

We, too, live beneath the whelm of what is our external nature; live on the defensive; live submissively beneath the play of forces alien to what we recognize as human and creative. We, too, have no highways in our wilderness, no signposts. And while the jungle lords it over us, we, too, real savages, respond with worship, model our divinities from its most looming and most cruel forms, adore its spawning and, immersed in the impervious skein, are happy with scant survival.

We are a nation of "gloomy, restless, harried, and neurotic people". 4 our present is filled with a lack of comfort, a lack of strength, a lack of the very things we sell our lives to gain.

Statistics shout their message of insanity, neurosis, torpor, disillusion, tiding upon this land of gold in which everything is for sale and nothing delivered...

\footnotetext{
1. Re-Discovery of America pp. 210-11.

2. Ibid., p. 70.

3. Ibid., p. 71 .

4. Frank; W., op.cit., p. 110.

5. Ibid., p. $2 \overline{24}$.
} 
Our family life is so disintegrated that re are unable to give to our youth the security and discipline and soulsatisfaction which are so essential if they are to have Iife and have it more abundantly.

Finelly, in our undisciplined youth there are dark reservoirs of hunger to serve, of unrequited idealism, of pession, which for want of a better course might be hurried down the sluices of race prejudice and violence. And our liberals and socialists, too (like those who helped forge the slavery of Hussolini and Hitler, and who failed to avert the disgrace of France and Britain), are fettered to an impotent rationa. ism which simply does not touch the springs of human action.

We need but to look closely et ourselves to discover

these seeds of chaos which are in reality man's humiliation.

Now turn from the outrard visible debecle of Europe's proud modern era to our own intimate world. To the state of the American family; to unemployment; to the confusion in our youth; to the false standards of "freedom" that have so sady "released" American women into sterile shallows and deprived American men of a necessery nurture. Consult your own life: the stifled good in you, the starving strength, the thwarted dreams. In your character, and your brother's, you will find fears, confusion, frustrations, dwindling faiths and values which, in the transmutation of orisis become the fuel and the traits of Fascism. 2

Our so-celled "practical" men, those to whom America looks for the solving of her ills financiglly and

1. Chart for Rough $\frac{\text { Rater }}{\text { Ibid. }}$, po. 21-22. 
economically, have not aided us in finding our way through the Jungle; on the other hand, they have added to our chaotic condition.

They solve the question of life by begging

it. They exalt some fragent-person, caste, church, state, property, reason- and declare its autonomy over al1. Their course is the stremn breakage of spirit, which is wholeness. No matter. Since they coin money and bury their dead, they are called "practical" men. Since they fulfill the process of decomposition whereby 1 ife is renewed, they are practical men. 1

We are a poople who today do not accept the "integer of our Great Tredition" 2 - which, defined, is the knowledge that individurl man partakes of the divine, which is his ray of naming the universal and of naming it good and of naming it his. It is the knowledge that his life has purpose and direction because God is in him. 3

Our current arts, music, painting, literature, and other forms of creative work are also the victims of this condition of American life. Our artists connot create Wholeness for people who are chaotic and who demand works of art as diseased as they themselves are. Mr. Frank makes this statement: "The average American book aims to titilate some flabby woman (in partnership with o box of candy)." 4

A work of art is a particular constructed body from which is to be derived the experience of unity between the self and what

1. Re-Discovery of America, p. 216.

2. Chart for Rough Water, p. 101 .

3. Ibid., p.50.

4. Dawn in Russia, p. 167 . 
is not self. It is the simplest as

well as the ultimate expression of

wholeness. In a jungle of deliquescent, unassimilated forces; in field of Power

whose action, as we have seen, is against

this marriage of self with non-self, art

will struggle feverishly and fecklessly.

In such a world, it will be most cryingly

needed, most passionately sought for, most

difficult to achiove. Often it will be

corrupted wholly from its aesthetic purpose,

to become a mere mirror or apology of Power.

Often it will emerge impure from its matrix

of the world, maimed by the forces it should

fuse, stifled by the treditions which should nourish it. 1

This same chaos is to be found in our art, therefore. Our art expresses no unbroken wholeness, it sings no grest song of unity, because we are so blinded by our jungle that we have no conception of what art really is. We do not find today poets and artists who express the Great Tradition. They do not have that belief and faith which make mesterpieces.

Much of our ills can be traced directly to the dearth of leaders during the past century. Our progressive movements have failed; there has been a failure of morale and ethics; a failure due to the fact that our intellectuals lacked the humility to go to man's soul and spirit before they bogan large-scale work. Our leaders have been shallow men with visions more shallow still, and they could lead the people to nothing better than their own shallowness.

I. Re-Discovery of America, p. 128 . 
Thus Mr. Frank gives us a picture of America today. He says that he would not be able to paint such a gloomy picture if he did not, with eyes filled with love and faith, see some hope for us, if he did not know that we are capable of aring ourselves. 1

\section{What Has Happened}

Forces at work and movements, begun and ended long before the discovery of Americe, brought into being those currents which bore ever onwerd the seeds of our modern chaos.

During the Middle Ages, Europe was an "alive organic body" 2 whose heart, mind, and soul were the Mediterranean world of Egypt, Judaea, Athens, and Rome. This part of the world supplied Europe with its spirit and vigor because it within itself was one spirit. These people had certein convictions and laws which "made the House - organs that made the conceptual body - of Western Europe. Surety they were, and substance, of the experience of western man ... Within them men lived and died, and created beauty and found truth: men before Isaiah, men after Shakespeare ..." 3

There were differences of opinion among the intellectuels of these countries, to be sure, but these differences were not fundamental or racial or cultural.

But those laws which established the spiritual anatomy

I. Conference with him. (Also) Chart for Rough Water, pp.22-23

2. Re-Discovery of America, p. II.

3. Ibid., pp. $\overline{I 2}-\overline{18}$. 
of Europo, the foundation blocks of the Houso, vanished -disappeared -- when the searchlight of science, reason, and modern thought attacked them:

European man, bereft of revelation, fell back on the science of sense; bereft of that he fell back, for surety, on self. Now the surety of self was taken from him. If time and space might be configurations of his thinking, cause and effect become mere relative sequence, and the thought which found all things within this time and space was turned destructively upon itself. The great Body of western experience broke down; and we were hurled into modern chaos. You can gauge the state of Europe's cultural decomposition, by contrasting it with the Body wherein Dante dwelt. Everything there had its place, moved with purposive rhythm into the Whole. From God to priest, from Emperor to serf, from Heaven to Hell, from star to atom, from good to evil, all was integral ... That Thole is gone. 1

The span between the Thirty Years' War in Europe, 1618-1648, and that of the first World War is the modern era. It was established by that "century of genius",2 the seventeenth. It was consolidated by the eighteenth and nineteenth, and "the twentieth century, before it was two decades old, announced its end." 3

The eighteenth and nineteenth centuries were shallow because they accepted the concept of the individual without the divine, which alone could make him whole and true.

1. Re-Discovery of America, p. 14 .

2. Chart for Rough Water, p. 28 .

3. Ibid. 
Such e brief time for the life of a culture, certainly one Which began with such promise and power, is strange. Its great men agreed on one thing. only - that decay had already set in before it, was half ripe.

The orovth of such disintegration from the time when Iife was good on the Nediterranean shores is soon told. In the Christian Middle Ages of Rurope, the people believed in whet the Gospels taught: salvation. It was a wonderful truth for the peasent and sorf, for their life on earth was a hard one, and they had only their belief in a better. world to sustain them. They looked longingly toward the true life with all its glory and comfort. Such e belief leads one to call the Middle Ages comparatively successful. It was clear that the modern value was not to be salvation, however, In Protestant countries, salvation wes relegated to the domain first of princely provincial suthority, then to private opinion. In the catholic countries, church power dimmed and was finally disestablished. Then stote and public education disclaimed all rights to the preaching of salvetion. Art and literature soon ignored the subject.

Beneath all the many contingent reasons, the basic cause of the humiliation of man in the modern world is his forsaking the Great Tradition. It has been romewhet different and has had many forms during the several centuries, but its essence hos never changed. The noture 
of the diserse is this:

The individual soul, fed and grown great by its awareness of the divine within it, believed it could dispense with tho divine. It had learned freedom within religious Necessity-the one true freedom. Now it decided to destroy Necessity. The ego was its own, it decided; its efficient cause would no longer be God or Cosmos, but self-served by self-sufficient will and reason; its principle of action would no longer be service to God (a kernel of intuitive truth in the idea of salvation) but self-circumstantial well being.

This rebellion of the ego, grown great by the truth of the Great Tradition, against the Great Tradition, brought about mañs humiliation. I

The sense of the Whole was destroyed, and this sense Mr. Frank defines in this manner:

Wholeness is no mere desired goal; it is the origin and the end of all our creative being. Wholeness is one in life as in letter, holiness and health. Wholeness must be both personal and social, in order to be either. Individual man cennot achieve his health unless he live, consciously, within a Fhole that holds ali life.

This Wholeness is the background of value which alone can make valid the America we desire. Religion, which the modern world has discarded, in its highest sense is the deliberete building of a whole, and this brings up for consideration the mystics. A mystic is this:

Now there are certain men who know the unity of the Whole of Being--including, of course, themeelves--in the same way that any man knows the unity of his person. These men have been called the mystics. Their sense

1. chart for Rough Vaters, p. 51.

2. Re-Discovery of America, p. $19^{\circ}$. 
of Wholeness, without abandoning the personal which is its core, reaches beyond it. Since they are called mystics, it is well to cell their sense of the Whole the mystic sense.

He goes even further in outlining this Mystic, the

person whom we find so often in his novels:

The mystic sense of the Whole, since by definition it trenscends the person, must transcend and transform the personal wi11. The man whose "universe" is but the tool of personel desire has no real universe at all: he has reached the order neither of pure science nor of religion. 2

This mystic sense, then, whose absolute perfection is religion, is "the latest and least dereloped sense of $\operatorname{man} . " 3$

"...no true sense of the Whole can suffer the exploiting of its knowledge to partial, personal ends. In it, the sense of selfhood, by definition, becomes transfigured; knows immortality in the act of knowing the mortality of the person.

- - The mystic sense of the Whole is unthinkable, also, without the personal core. But it differs basally from the personal whole-sense in that it is no longer absolutely personal: body and person become the focus for the immediate experience of whet is beyond (although including) them; the common sense of self is trensfigured into the sense of life.

The true mystic is a neturalistic monist, in whom man's instinctive impulse to assume a whole, and intellectual effort to create one have joined and become integrally conscious. 4 From these definitions of a mystic and the mystical

\footnotetext{
1. Re-Discovery of America, p. 24.

2. Ibid., p. 27 .

3. Ibid., p. 28 .

4. Ibid., pp. 28-29.
} 
sense, one may make the immediate application that:

To be unconscious of the Whole is to live in terms of the pert as if it were the whole: and this-the way of animals and proctical men - is to be unconscious. To be conscious of the Whole is to live in terms of the Whole expressed through its parts; and this - the way of the mystic and man - is to be conscious. 1

In this manner, one begins to arrive at the true reason for the present condition of the human beings who compose our modern morld. Science, hoving destroyed this mystical senee of the Whole, fulfilled our chaos, but its complete work was not finished, even then. "It had to bring a monster in our midst; on anarchic mindless master in ploce of God, to trammel us and rule us. It put upon disrupted modern man the embodiment of his om dissociate will. The Machine... $\$ 2$

Today the machine is intricately bound up rith man's will. To understand thoroughly why the machine has contributed its share in fostering and disseminating chaos, we must have clearly before us its relation to will. "The full-born individual man"3 in its highest sense came from Jesus. In Jesus, to incernote the individual's bond with the universe, there is love: actual tender love of all life. To render it dynamic there is will, and this will as exemplified in the life of Jesus is the greatest contri-

I. Re-Discovery of America, p. 212

3. Chart for Rough Water, p. 110 . 
bution of the Galilean teacher. His teachings were no passive campaign, but one requiring action and will. The individual as a being responsible for the nation and the world was born, and this universal individual survived far into Christian Rome.

There came into being, however, conservative and containing forces which demanded that the masses crucify their will. Now the humble brotherhood in God lodged in a will for ego survival which "corrupted christianity's divine intuition with 211 the lust for aggrandizament, all the pill for being separate, which sullied the great Catholic republic and doomed it."l

When the world, following the scientists and the discoverers into action and progress, began to move and to know motion, "this progress made of mankind an infinite measure".2

Within this amaing world of newly infinite man, the intellect wes bound to lose prestige, and to give way to the will. The intellect considers, defines, makes finite. The intellect knows no infinity. But the will acts, moves - its world, from indefinite, grows infinite. Duns scotus and William of $0 \mathrm{ccam}$ had, before their time, declared the independence of will: from the disintegrant north had come this note that was to shatter the symphony of Europe.3

The wilful individual went his way, and two adventures may stand for the whole release known as the modern era:

I. Chart for Rough Water, p. 115 .

2. Re-Discovery of America, p. 35 .

3. Ibid., p. 35 . 
(1) the discovery and settlement of America (2) the invention, exploitation, and proliferation of the machine. The modern machine is the product of the "individual will released from medieval synthesis", 1 and it will free man when man is once freo from his present enslavement of the will. From a spiritual whole, men became wilful atoms, and, having completely lost their God, they began to worship their own desires. "Therefore the machine, most perfect symbol of personal desire, was turned into an idol: man identified himself with it and made it the object of his self-adoration." 2

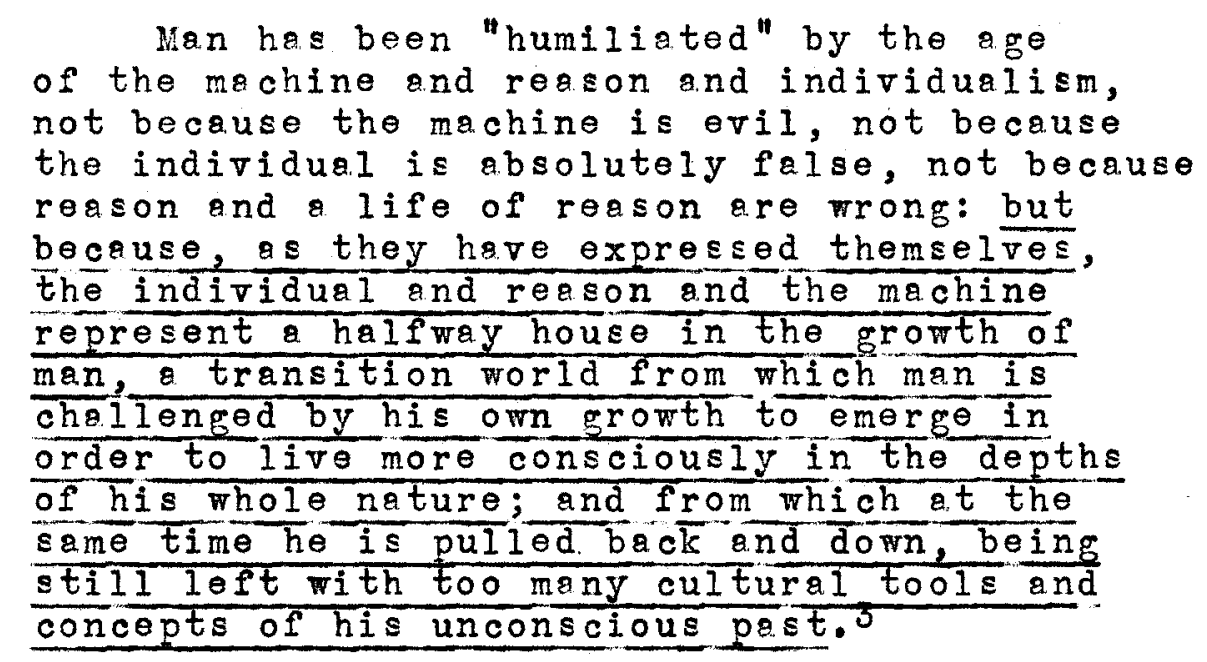

And finally: "It is still nakedly the symbol of man's personal will imposing itself over the world outside him. Therefore, it embodies no consciousness of Wholeness; it is not yet creative; it is dissolute end destructive . . "4

closely allied with the machine age and will is another creator of chaos, Power.

I. Chart for Rough Water, p. 120 .

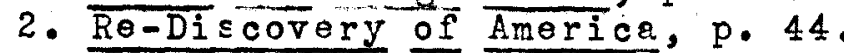

3. Chart for Rough Water, p. 121 .

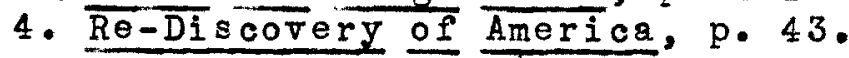


It wes not accidental that Nietzsche, who was a child of Europe's chaos and who refused 011 unity to life, deified the will-to-power. Power is the god of the one who eccepts only himself. Power is the imposition of the one upon the external world.

In the polity of Power, what counts is the one: what must survive is the same one. All outside this one must submit or be destroyed. Power is the expression of the brute, of the savage, of the child, of any being whose self-awareness has not spread beyond the majesty of personal will. Wherever energy remains in the stage of individual enhancement, it becomes Power. The renesis of Fower, therefore, being the denial or unawereness of wholes beyond this individuel enhancement, is chaos; and the production of Power is more choos. For Povrer refuses to die within some synthesis greater than itself. A mass of power-persons cannot integrate, can form no organ or true society: they moke the herd whose sum is the cumulation of self-assertive atoms. 1

The reign of Power in Americe threatens to bring upon us complete ruin, for he who accepts the primacy of Power crucifies the sense of the Whole which is within him. He will lose his freedom and creativity and become a servile creature to the monster he worships, for Power renders a man pessive.

Since Love is a creative act, depending for its existence upon the fusion of any one thing with another so that the two become one, it is the entithesis of Power. "It may even be more poterful than Power, but it is not Power." 2 Because this theme is a common one in Mr. Frank's novels, I wish to quote at length what he hes to say about the relation of Power and Love.

1. Re-Discovery of America, $p .79$.

2. Ibid., $\mathrm{p}$. 79-80. 
My contrasting definitions of Power and Love are justified by the common experience of our life. The child begins with the assertion of his maked ego: he is a power-person; and he must be, ere he be ripe for love. Unless Love transfigure his ego, he will, however, remain a power-person: spiritually immature, creatively unproductive. But he cannot achieve the stage of Love, without going through the stage of Fower. The natural infancy of human spirit is an experience of Power; by means of Power this spirit is cultivated and developed. Only the ego which is strong, self-assertive, prone to Power, is ripe for Love. Love is no submergence of a woak personal will in others: it is the masterful, conscious fusion of the strong ego with ife. 1

Thus we come agein to the true condition of our society today. Our deplorable state, as we hove shown, is not the result of some accident or unfortunate catastrophe, but the fruition of centuries of acts and deeds which moved slowly toward chros. Mr. Frank sums up this state of affairs in this manner:

Barbarism (a state in which man accepts an untronsfigured noture ond odjusts to it and finds his values in it) lives on the plane of Power; and it is precisely in consequence of this that barbarous man is spiritually alone, forming no integral society but a pack or $a$ herd, and that nature, although he adjusts to it perhaps with consummate skill, remains ideally external, humanly uncreated - remains a jungle.

America is a herd longing to become a true society--frentically longing. It is a living plasm, a potential Whole, and it must reach its organic health or rot and die. It strives to achieve this goal of Unity, which is the fruit

1. Re-Diecovery of America, pp. 79-80.

2. Ibid., p. $\overline{82}$. 
of Love, by exercise of Power. It

legisletes, it organizes, it marshals

loyalty into institutions which, serving

specific ends, are mere machines. It

endeavours, that is, to force our birth and

growth. Thus, we enect $\overline{l \text { ws }}$ regulating

morals; thus gather in Rotary Clubs and $K u$

Klux Klans. Our purpose is good, it is to create a spiritual active whole from the chaos which we feel within us. But since

the means we use is Power-child of chaos - we perpetuate our chaos. 1

\section{What Can Be Done About It}

Even yet, man may change the jungle which is our American dwelling at the present for a way of life that is infinitely more satisfying. This very jungle may become material for "creative articulation".2 Man can achieve Wholeness by abandoning his mad scramble for survival and exploitation and by cultivating a sense of truth and beauty and universal joy.

There is a growing conviction that something is wrong. We have begun to question the efficacy of Power and to seek the cause of our lovelessness, to question why our love, placed in the domain of Power, is worse than futile.

We are a "capturable" people - we who have never remoined captured have never become settled. It is possible for us to end social chaos and come into a nation of Wholeness, but each individual must find that wholeness within himself. He will bring truth to bear upon a new world just beginning, not for "any issue in time or person,

I. Re-Discovery of America, p. 83 .

2. Ibid., p. 70 . 
but for the joy of the eternity of the moment lived in the image of God." I

Self and the will of self must be crucified.

The experience of true wholeness is

a light that can be centred sharp or wide;

illuming by its focus what is called self,

what is called the netion, what is called

the cosmos.

Even the machine can mean wholeness if wholeness is

in us.

Suppose that man achieves this wholeness

in terms of his action. The machine then may

become a means toward this wholeness - a means

of fusing his control over nature with his

control over self. At once, it will be a

symbol of his spiritual growth. 3

The possibility of integration is encouraging, therefore.

Past cultures have built the mature body; in intellectual, technical, and social parts, man's body is mature.

All that is needed is for these complex elements to integrate. That is the true maturing: the art of the spirit. The

individual integrated in his cosmos, I call

the person.

"To integrate the Great Tradition into our American Iife" 5

is the fundamental necessity. This is the new value which

will move and integrate the people. There is only one way

of finding it, and that is by finding ourselves. We must

synthesize the values of medieval Europe and the modern age

both in Europe and America.

1. Frank, Waldo, op.cit., p. 310 .

2.Ibid.; p. 211 .

3. Ibid., pp. 42-43.

4. Chart for Rough Water, pp. 126-127.

5. Ibid. $\mathrm{p} \cdot 156$. 
The value of Christian medieval Europe was supernatural salvation by grace. That is the simple Thesis of hopeful, helpless individuels. . . The Thesis value set us forth in life; fed us energy and dream. The antithesis value is trensitional; it helped man possess the body of his machine, to free him in it:. But it hos outlived its moment in our organic articulation and must go... unless Antithesis moves into synthesis, it will destroy us.

The essence of the Thesis remains: the eternal is in man and man's need to be saved is really his need to live the eternal in his nature.

The Antithesis value of well-being marks the reaction from the Thesis. Man's home, it replies, is here on earth: let him conquer the earth end establish his salvetion here; let him be happy here.l

When these tro are merged, with resson preserved as a generglizing instrument of control, you have the synthesis. Finally the person (that individuel through which the Cosmos speaks) instead of the unreal individual: salvetion that lets us live our lives now by the knowledge, will and experience of persons rather than salvation in enother world; and

- - instead of grace blincly bestowed by myth, the grace of our creative intuition of the God in us, leading us, with reason to help, to create humen relationships, cities, countrysides, nations, in which persons can live. And instead of an illusion of wellbeing premised on the denial of man's tragic dimensions, of men's mystic dynamism which trke their revenge for their noglect by reeson in such mad movements as Fascism, a harmony of the whole of human nature.

\section{Frank, Waldo, op.cit., \\ 2. Ibid.,}

pp. $157-8-9$. 
Synthesis must be the keynote of our existence. How? Our cultural criticism must be revolutionized by the acceptance of the new value as the norm; schools and colleges must revolutionize their disciplines by the norm of the new ralue; it is high time to found a new political party which shall understand Blake's deep dictum that true politics is religion; underneath all, there must be persons and groups of persons. The synthesis value is more integral and urgent then a compass. It is the latent potential of our loves and loyalties. It will carry us through. 1

A socialized state of America which shall be a union of persons and of groups of persons working in an economy of plenty, A union of peoples in a confederation of peece is no idle Jtopirn dream - It is the true beginning.

I. Frank, Waldo, op.cit., pp. 161-171.

2. Ibid., p. 176 . 


\section{AMERICATI HOUEN}

ur. Frank has mode a coreful and comprehensive study of the position of women in this American Jungle of clashing wills and dominant Power. A presentation of his convictions and conclusions seems a necessary background for an accurate analysis of the position of women as presented in his novels.

The order in which my meteris.1 is presented is the same one which Mr. Frank uses in his chapter "Our Tomen" in The Re-Discovery of America. All the material for this section has been obtained from this source, from letters which I have received from the author, and from a conversation which I had with him.

In order to be able to discuse the problem of women with any degree of lucidity, Mr. Frank first exemines meticulously certein myths concerning them.

1. It is said that American women are very independent, due to the industriel revolution. This is en erroneous statement, because their nature, molded by eons, could not be changed in the short span of fifty years. Then, too, women have always been in industrial work, the difference being now that the work has shifted from the home. That is true of men's work also.

To judge the men of a land in the whole context of their world, and to judge the women who share the world, by a few special cases, is silly and romantic. Many of our 
hord-headed interpreters of women are closer to the minor poet who sings of woman as a Thing Apart, not wholiy human, than they would like to be told. Since girls in a modern Paris office feminise that office into something redolent of old France, and since girls in an American office do not feminise it at all, clearly the office and the fact that girls are in it are not the crux of the motter.l

2. The claim thet women are the strength of Puritanism, sex-censorships, and personal prohibitions in America is equally false. Wen first set up the ideals of Puritanism both in Europe and in America.

The ideals of Puritanism are not alone a man's concept of the world; they are hostile to women. It is not natural for woman to disdain the senses and the body; to be transcendental. It is obhorrent to her to repugn sex, to seek values in the hereafter, to slight this life in mystical evasions. Nor is it natural for woman to be a restless pioneer, to disdain the soil, to idealise motion and change. . And whatever organic resistence Puritenism has met in the United States has been due in large part to women. While pioneering, Puritanism's ally, wes the cry of the lend, moman's aloofness from its alien ideals was overcome by her need to conform. As soon as conditions allowed, her veritable neture-the nature, indeed, of any woman loosed from the bond of man-made culture-spoke: she showed herself emotionally honest, spirituelly childlike, sexually alert. The clear, unconsciously rebellious savage whom we call the flapper may stand for the essential woman of America, left unchastened and uncultivated in our stockaded towns and at last released by the fall of the stockades. ${ }^{2}$

1. Re-Discovery of America, p. 184.

2. Ibid., p. I85. 
American democretic rules, and not the momen, are responsible for sex-censorships. Our lews merely reflect the ottitude of the masses, and that attitude in our ountry is that sex is a private matter that must not be discussed.

3. The third myth to be exploded is thot the United States is a matriarchy. This to Frank is ironically false.

If the American woman has been forced by the conditions of our Jungle to become an ogent of masculine behaviour, to aceept ideals thet corrode her stronoth, to live a life that belittles her home, to imitate men and almays in subaltern ranks; if her strugsle for a place has pushed her into man's business, man's politics, man's art, where is her rulership? Is it logical to say that momen are strong in a land where men have forced them to oct as if they were replicas of men? There is probobly no country in the world where women hes had less chance to be women, less cogency as woman, there she hes been so entirely on the defensive; and where the re-establishment of women in her organic role is so sorely needed, es in ours, for the fulfillment of the folk. This false idealising of the American womon's "might" (in her heort she detests it) is the Americen man's compensetion for his failure to let his woman live; a failure from which he suffers $\bar{a} \bar{a} \operatorname{man}$. The cure for all this nonsense, with which distinguished visitors and lecturers regale us, is to see what happened to women in our forming world... I

Having been uprooted from their homes in Europe to seek a new life in Americe, women worked hord to make $a$ home here. Religion and morals, because they were the strongest hold women had on their men, became $a$ till-

I. Re-Discovery of Americe, pp. $186-7$. 
expression by means of which the women tried to touch their men. Etrical and mystical tenets were of use in helping her make a home in the chaotic world.

The American pioneer was not a good lover, and his failure was not due to dangerous and arduous tasks. "His failure as a lover lay in his very issuance from Europe."I

We hove studied the process of atomisation that made the American man a particle of Power -- a driving instrument of action and self-will. Love we heve defined as the principle of union, of order, of creation - the act whereby the two or the many become one; and Power is the imposition of a self on any object by destruction or absorption - the principle of chaos. Any man

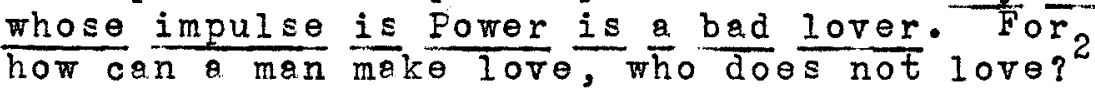

And thus the American man, dominated by Power and not by Love, became the maker of chaos in the relationship between him and woman. He no longer found fulfilment in his wife. It is not strange, then, that marriage faded and divorce began its ascendancy. Because moman and her family became merely a means, the end of which was Power, and since man did not fulfil her, "as a creative being"she was not fulfilled." 3 It is true that "luch of the male American's emotion (which American women need to become women) goes to the machine." 4 The woman suffered from this lack, and, bereft and frantic, she followed into masculine chaos.

1. Re-Discovery of America, p. 188 .

2. Ibid., pp. 188-9.

3. Ibid:, p. 190 .

4. Ibid., p. 93 . 
Woman became what she must, in a reign of Power. She went efter her man: she went outside herself to be like her man - to win from herself what she had always gotten from the man she had lost. Self-Fulfilment - the fallacy of Power. There begins the spectacle of women who worship self, since their men worship self: of men and women turned from one another and hence barred from the sole true self-fulfilment which is the union of the self with another self, of the one vith the world. The men had their outset in the nucleus of their own personal will; they were immature, yet they were beginnings of men. But the women began by doing violence to their nature, by toking men's will as their outeet. 1

By imitating men and by etruggling against the depreciation of home values, "our women beceme poor cooks, unsatisfactory wives, neurotic mothers". 2 their tool of morals and religion, which they had vainly used to save their homes, began to be used as a weapon, "destructively, aggressively, to sterilize the world, since they were sterile". 3

She has learned that all this business of imitating men and of resorting to other substitutes was doomed to failure. Today,

- the feminist movement, is dead. Woman reverts to the sources of her womanhood: to \& new, hard, shrewd, unsentimental femaleness. She is an atom: from the fruit of the experience of her mothers, comes this seed of a folk. She is pure of the old seasons, purer than man, readier to dawn. Wan cannot win her by tugging the old chords of sentiment, tradition, law - chords himself has cut. He must begin, to meet her beginning. And it may be that

1. Frank, WeIdo, $\frac{\text { op.cit. }}{\text { 2. Ibid., }}$ pp. $190-1$.
$\begin{array}{ll}\text { 3. Ibid., } & \text { p. } 192 .\end{array}$


the first step in the creation of a Thole from our Americen chaos will be the union of men with this new Eve who was not

formed from his rib... I

The aloneness which his women experience, he sees as arising in pert from their refusal to relinguish their will. It is due also to the seme elements thst make our chaos, for this same cheos renders the men inadequate to fulfill her needs. Fe defines this eloneness thus:

The individual who is felse is insecure; and the individurl tho is convinced of his orn seperete, substantial ego is false. His aloneness, Thich is his conscious bosst, is his unconscious anguish. Ee knows, more oreanically then all his proud assertions, that there is chaos and $a$ lie in him. He distrusts himself. Therefore, he distrusts others; particularly those "ho are most kin to him and with whom he mill strive to form a group. 2

Thus there are meny problems confronting the modern moman that must be solved before she emerges from the state of chaos in which modern society finds itself. To become wholly integroted, to incorporete within themselves the Great Tredition, to find the plece end the work which God hes for them to do, to b come, in short, persons, are the essential means of solving the problems.

A description of the women in Kussia as Waldo Fronk soes them will serve to drew an enlightening contrest with American women:

There is intense emotion in Russie's personal life. Women here ere women indeed.

I. Frenk, Naldo, op.cit., p. 193. 2. Ibid., p. 279 . 
They merch unafraid into the public turmoil; they work beside men in factory, mill and office. When they travel they sleep beside men, when they bathe - if need be - they bathe naked before them. They are unafraid of their bodies, they are so accepting of essential womanhood that they can forget about it when other phases of life absorb them. In their sexual relations, they meet men freely - spirit to spirit, unaided and untrammeled by conventions. Yet how womanly they are! how ripe in their tenderness and loyalty to their own notures! Here, in the Soviet Union, the Strindbergian warfare of the sexes seems to have no meaning. Here is no male will (the morbid will of the novels of D. H. Lawrence) pitted against a "terrible mother". Childlike and wise, these Russian men and women of the new age seem to share in the work of making it - in the ecstacy of peopling it. Each has what the other needs to share fully. "Let us work - and play and let us love - together."l

Mr. Frank has always had a love for what woman actually is and has seemed to be able to understand their problems and positions. Becouse of his sympathy for them, he has been their confidant in many kinds of troubles and on every sort of occasion. He insists that they have had a raw desl. His women characters have certain traits and appear in certain lights, because, as he stated, he has certain experiences and makes certain observations which are multiplied many times over before he draws his conclusions. As we analyze his women, we shall see that he deals with them sympathetically always, never failing to present their side of any problem fairly and sensetely.

1. Dawn in Russia, pp. $51-2$. 
PART I

CHAPTER III

THE NOVELS AND THEIR THEHES 


\section{PART I}

CHAPTER III

\section{THE NOVELS AND THEIR THEMES}

The purpose of this chapter is to give a synopsis of the novele and to sort out the basic themes. The synopsis seemed desirable in itself, since several of the books are out of print; it elso serves as a background for the analysis of the major aspects of Mr. Frank's treatment of women in the second part.

The main point of this overview of the novels, however, is to arrive at the basic themes pertinent to the treatment of women. A chart of these themes is given for handy referenco. 


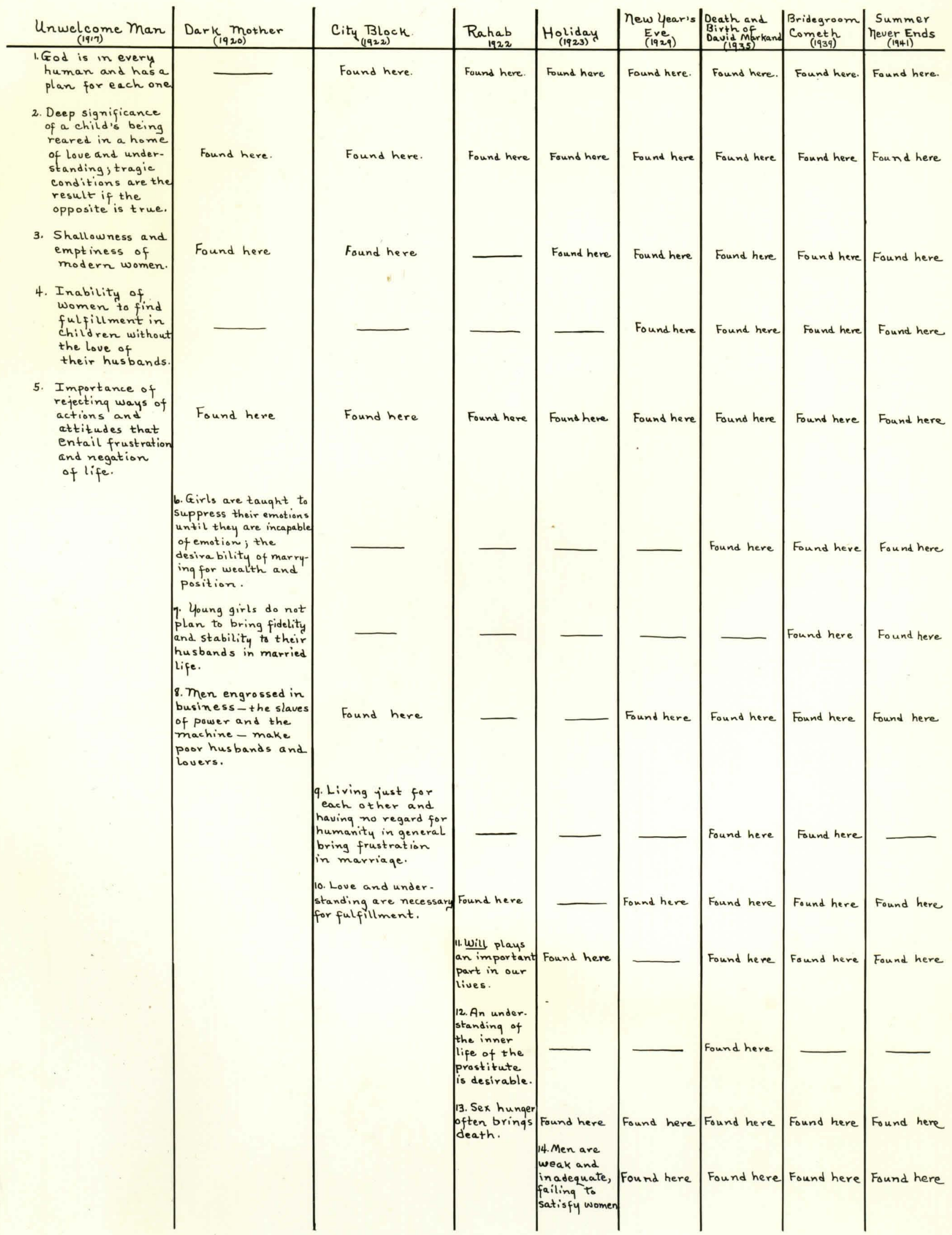


The Unwelcome Man (1917)

The Unwelcome Man is the story of Quincy Burt and his struggles to understand his family and the world with which he comes in contact and to be understood by them. It is really the story of Quincy and his individuality against everyone whom he knows. The book is divided into three sections: Number I covers the period from his birth to his entrance into college; Section II relates his struggles during his three years in college; the third describes his next two years spent in the business world.

Quincy struggles throughout the first period to adjust himself to his family: the father, Josiah, who blamed Quincy's birth for all the ille thet later befell the already toolarge family; the mother, sarah, who tried futilely to bo an integral part of her family; to Rhoda and Adelaide, his sisters; to Marsden, the crippled brother, and to Jonas, the lively favorite of his father.

Period II is distinguished by Quincy's struggles to become edjusted to college life; his love for Professor Deoring and his falling in love with Deering's beautiful wife, Julia; his sexual experience with her, end his decision to leave college because he cannot adjust himself.

Period III depicts his entrance into the business world; shows his efforts to court clarice Lodge and his failure; and his final acceptance of the business world as the only life bearable. 
The psychological study of quincy os he tries to live peaceable in the world with other people and still maintain his own identity is the main theme. The author's firm conviction that one should reject ways of living and acting that enteil frustration is a part of this theme. After one of quincy's breaks from the beaten path, the author takes time out to observe:

And, now, the Fark ras bohind him. The adventure stood et its climax. And if there be gods who cease at times their celestial indifference, when the gleam of a real heroism smarts in their dull eyes from earth, they were now watching Quincy. Learn the book of life and the nature of the heroic becomes plain. It is the deliberate negetion of whet is sense and rote, of that which the interminable overage makes life; it is the disarowl of a.1 laws, the compliance with what is but a shadow, a shred, and a suggestion. It is the leaning on an instent and the despising of all time. It is the paradoxical resolve to prove a spot of star greater and wider and more important than the mass of earth. It is the truth. And it is even more, for it is the acting on it. 1

Quincy fails to be a hero, for he accepts those tenets of life which the author sees as the breeders of our chaos. More than that, he is one of those who deliberately become "unconscious of the Whole" living "in terms of the part as if it were the whole; and this - the way of animals and practical men - is to be unconscious." 2

The mystical experiences which are to be perfected to an artistic entity in his leter novels are quincy's. Then, too, in clarice, one sees the worldiy, shallow girl

1. Frank, Waldo, The Unwelcome inan (Boston: Little, Bromn, 2. Re-Discovery of America, p. 212 . 
Who is incapable of giving to quincy the stability and the sound basis for living that he needs.

\section{Dark Mother (1920)}

Dark Hother begins the story of David Markand which is continued later in the book, The Death and Birth of David Markand. This book is really the battleground on which are fought the conflicts between Markend, the dreamer and idealist, and his friend, Tom Rennerd, the hard, disillusioned, worldlywise, young lawyer. It is the story of Dovid's efforts to integrate himself and fit into the world where he must earn his living. It is also the conflict between Tom and his sister, Cornelia, for the mastery of David. Tom sets out to destroy Dovid's foith, shatter his dreams, and disillusion him completely. Tom, like quincy in the first novel, has sold out to the morld and its evil, and he, out of sheer envy of David's ability to stand proof against the world, would destroy him. Cornelia, the successful sculptress, learns to love David, and she strives to counteract Tom's influence and assist David in preserving the best that is in him.

David has come to New York, after the death of his mother, to work for his uncle, Anthony Deane, who is head of a large tobacco firm in New York. David is always bewildered by the business porld, but he is never drawn into it. He lives with the Deanes where he falls in love with his 
cousin, Lois. When he leaves there, after being disappointed in her, he lives with Tom Rennard. Tom and his sister had run away from an impossible situation at home years before and had wrested from the city success in their lines of work. They were not happy, however, for they seemed to be an ill-fated pair. Cornelia eventually introduces David to Helen Daindre, a young scientist, whom he marries. She does this as a final gesture to save him from Tom, and then she commits suicide.

Several themes appear here. The eternal struggle of a human to become an integrated personality, the search for a full life, and his efforts to live the eternal in his nature are found in Dovid's struggle. The author is painting the evolution of a full, integrated person, ond, if the work of art remains unfinished in this book, we find that David achieves this integration in The Death and Birth of David Narkand and The Bridegroom Cometh. These three embody well the monistic naturalism that Mr. Frank sees as essential to the true mystic and the real person, for in David and liary Donald (Bridegroom Cometh) we have the instinctive impulse to assume a whole joined with the intellectual effort to create one, thus becoming integrally conscious.

One finds in Marcia Duffeld, the girl with whom Tom hos a love affoir, the willingness to indulge in sex relations with a man who cannot be her husband, and the ultimate acceptance of a loveless marriage for financial 
reasons while she plans to see often the men she does love. There is the suppression of natural feelings in Lois and Muriel Deane, and they would not think of marrying anyone who did not qualify socially and financially. One finds, too, the falseness of society, the shallowness of its romen, and the ineffectualness of the business man as a good lover end husband.

\section{City Block (1922)}

This is a collection of short stories tola about the people who live in one single block in New York City. It is composed of fourteen stories whose characters orerlap and relate to each other, although most of the stories could be published independent of the others. I use these plots and characters in the development of my thesis, but I have given a synopsis of each story as I have used it. That makes it unnecessary for an overview of each one of the stories at this time.

$$
\text { Rahab (1922) }
$$

Rahab portreys the Iife of Fanny Luve as she runs a house of prostitution in New York City. It is a story of how Fanny came to accept this sort of life and leads to a deep understending of the prostitutes who live vith her. The setting is in such a house, and Fanny recalls oll the years of her life as she sits and talks to a men who has 
come there to see one of the girls.

Fenny Dirk as a young girl had given herself to her lover, Harry Howland Luve, and after their experience, he decided that they must merry. After marrigge, he drank and gambled continuously as he pretended to complete his college course. Then one night he became mixed up in a particularly revolting braw where a wom was found halfdead, and his evil life caught up with him. His gambling debts were heavy, and he simply disappeared to keep from facing the consequences.

Fanny did not hear from him, although she waited patiently and trustingly during the days of her pregnency and the birth of their child, Edith. She had borne the pity, scorn, loneliness, and the gossip of the little town for eight months after Harry left when she met Leon Dannenberg, a Jew from Washington. He accompanied her to her home, and through her sexual experience with him, she learned that she still loved her husbend and saw clearly again that she must wait for his return. Because Leon believed in her and in her ultimete mission in life, she begen to believe in herself. Throughout her life, this one experience with Leon is a guiding light.

Harry spent two years in drinking, gambling, and adulterous living. He was converted and became a preacher, however, before he returned to his home. Fanny, completely happy over his coming, listened to his recital of his sins, 
forgave him before he had told them, and assured him of her faith in their future. She then confessed to him her one experience tith Leon, and Harry cast her out, refusing to live with her or to own her as his wife. He would not let her have their baby, Edith, and she went forth from home and friends, condemned utterly.

She passed through a period of despair in New York, questioning even the existence of a God whom she believed had cast her aray irrevocably. She secured a job in the firm of Christopher Johns, a loveble, kindly man, and it was not long until she had consented to live with him. This relationship lasted tro years, and she terminated the affair because she believed that further association with her would only poison him.

It was then that she, sick and despondent unto death, met again Clarg Lonergan, a girl with whom she had rorked in John's office. Clara nursed Mrs. Luve through a long period of severe illness, and it was Clare's love and concern for Mrs. Iuve that caused her to decide that there might be something in life for her to do.

She did not felter in her worship of clara when she learned that both she end all her girl friends were "kept" women, and Fanny eventually met them all. Their men were crooks, law evaders, and corrupt politicians, but Fanny came to like them instead of judging them. They, in turn, respected this serious, quiet, understanding woman. Thus 
it came about thet a house was rented, and Fanny became the mistress. Through her six years of keeping this house of prostitution, the friendship and love between her and Clara was the one glorious thing in Fanny's life.

Beceuse she refused to betray one of the men who came there by, letting him be trapped in the House, a policeman who had frequented it from the first closed the plece, and Clara and Mrs. Luve were thrown into the street. Clara died of pneumonia, but lirs. Luve opened up another house with other girls.

Fonny is a woman whose inner spiritual life is in seemingly sharp contrast to her outward condition and behavior. Believing on God end calling upon Him frequently, she is, nevertheless, an associate of crooks and prostitutes. She has been able to reconcile the one to the other because she had first learned to love clara, and later, she heerd the stories of the other girls' lives and wes able, through understanding, to love and accept them. By nature, Fanny is a mystic whose soul is suffused with a deep, abiding faith in God and in the fact that He has some place for her to work, some mission for her to fulfill.

This belief in God and that He has a job for her is one of the main themes of the book. Fanny comes to be a fully integrated person because she comes to love and understand people; she refuses to judge them and condemn them, for that is the way to death. Waldo Frank, in this book, 
reveals his belief that even prostitutes have a right to our understanding, and that often they are forced into this kind of life because of the harshness of social conditions. Our wills and the great influence which wills heve upon our lives are demonstrated here. The use of poetic symbols to reveal the soul of Fanny is very effective.

\section{Holiday (1923)}

This is the story of the affinity existing between a white girl, Virginia Hade, who lives in Wite Nazareth, and John Cloud, a negro boy, who lives in Black Nazareth, parts of the same town on the Gulf cosst. Lank John cloud, a magnificient yet tragic negro, is portrayed in the background of his home, his mother, and his fiencee, Mary cartier, who cannot bring him peace because of his longing for virginia. She is seen in her work and in her relation to father, brother, and the entire white colony. They are both filled with yearnings and longings which they cannot understand and yet which tear their very souls and alienate them from their families and friends.

They come together one afternoon on a hillside, acknowledging their yearnings. It is he who finds strength to leave with no more than a straining of bodies together, - tense handclasp, and a look of unutterable longing. She resolves to wash herself clean of her desires and restless urgings by giving John up to the mob. She tells her father 
and brother of John Cloud's effrontery in daring to look at a white girl; and they organize a mob and hang him.

The characteristics of this book are: the manifestation of Virginia's evil will which poisons all whom she touches; for seeking for peace and fulfillment; the blood taint transmitted to children by their perents; and the fact that sexual desires often bring death.

John's mother is a mystic, and Virginie Hade is the woman who denies the way of salvetion in life because of the deep-rooted prejudices of her family and her people.

\section{Chalk Face (1924)}

Chalk Face is the only one of Waldo Frenk's books rrich I did not use. It odded nothing to my study of women, and I am omitting it from this overvier and from my thesis.

\section{New Year's Eve (1929)}

The ploy, New Yegr's Eve, relates the stories of three families who ore close to eoch other in friendship and love. The setting for the first act is a New Year's Eve perty at the home of the ifachanes a fer minutes before 1900 is ushered in. Tro merried couples and an engaged one are there to relcome in the new century. The opposing forces and the cheracters may be seen from this table:

Laura NacShane loves Albert Benison end is to heve a beby by him, although she is married to samson.

Nancy Bowe is the opposing force to Laura. She is engaged to Benison and intends to marry him. 
Holt Trubody Laclede loves Samson Macshane, although married to calvin.

The Machanes heve two children; the Laclede's have one and are expecting another.

Albert Benison is the opposing force to CaIrin and Samson.

Alan is first the spirit of Laura's unborn child, then he becomes later the motivating force.

In the first scene, Laura renounces Albert and refuses to take his love, electing to remain in MacShone's home as his wife and mother of their children. Albert pleads for love to triumph, but he had his chance once to merry Laura and shirked the obligation he thought it would entail. The spirit of Alan is present even as they drink their toast to the unborn children of the future.

The next five scenes present these children sixteen years and twenty years later. Lawrence, the poisoned son of the Machines, loves Cleo, the poisoned daughter of the Benisons. They hesten to their self-destruction.

Trubody, the son of the lacledes, has rushed to war to escepe the hate in his home, and he returns, blind and broken, only to love Nan, the wife of Benison. She leads him to his destruction. These various forces and lives are disjointed, ruined, miserable. Alan alone, the child of love, loves and understands. It is he who brings peace at last to the Macshones.

The central theme of this play. is that children born 
into a loveless union are poisoned. Strongly developed, also, is the idea that people who deliberately renounce love and cling through fear to conventionalized standards accept that way of life which leads to misery ond evil. It is Waldo Frank's idea again that to love is to live; that to accept attitudes and circumstances which lead to frustration and negation of life is to create chaos and disintegration. Through the loves of these younger people, we see that often sex hunger brings destruction and death. That life is holy and that there is a truth which one can live by if he only searches for it are other themes found in this play.

\section{The Death and Birth of David Markand (1935)}

The Death and Birth of David Markand is the modern American man's Odyssey. David Markand, a successful and prosperous business man, decides suddenly to resign from his business, leave his home, wife, and two children, and go into the prorld in search of himself and a truth to live by, -in fact, to learn the real meaning of life and his place in the scheme of things.

He makes this decision after he learns that his wife, Helen, has joined the Catholic Church as a result of her efforts to find a deeper meaning to life and for something to fill her emptiness. He provides financially for Helon and the children, but his son, Tony, dies soon after he leaves. Some months fter David leaves, daughter is born to Helen. 
David goes first to clermont, the old home where he was born. Here he meets and loves the happily-married Polish man, Stan Poldiewicz, and his Kansas bred wife, Christine. Deboreh Gore, a widow who had known his mother, comes to mean much to David. After her jealous son has spread rumors about David and Mrs. Gore, they flee clermont before the mob, and Deborah goes as far as Chicago with him. Seeing him determined to continue his search, she feels that her mission is over and returns to clermont.

After a series of adventures with men and women from all classes of society and all occupations, Darid arrives at the home of Phil Dwelling in Kansas. Christine is there, too, for her husbond has died. Here Markand helps Phil and his wife Hester in their efforts to organize the farmers.

David goes next to Chicrgo. Helen and the baby come there to see him, but he realizes that he is not yet ready to return to her way of living. Instead, he secures a job in a slaughter house and works until he hos a complete breakdown. Two hexicans, Juan Fierro and his wife, Marita, take care of him until he is rell. It is then that he meets the wealthy, spoiled Theodora Lenck, wife of a packing house executive who is too weak to hold her love or interest. She and Markand are physically attracted to each other, and they live together for more than two years, each trying desperately to find themselves and ultimate peace with the other. Ted takes him South to the New Forld School in Lucy, Alabama, in 
her efforts to possess him completely. Her refusal to surrender her dominant will to his, and her dissatisfaction With less than all of him eventually separate them. She goes to Hollyrood end leter kills herself. Warkand becomes allied with the lebor movement and looks to his work with them for his salvetion. After he sees his friends, John Byrne and Jane priest, killed in Howton beceuse they are labor organizers, he makes his way to washington, and, as he gets in touch with Helen, through his lawyer, Tom kennerd, he realizes that he con now return rome. He knows "that it was the a wakening will, within the body of death that was still he and the city and the world: the will to overcome itself at last, and be reborn." I This vork is more than the wanderings of one man. It is an indictment ageinst the entire structure of society in America. Taldo Frenk wrote this at a time when he had accepted the tenets of the cless struggle. He believed in the establishment of collective society but never in the orthodox lfarxist form. His leanings tomaro labor and its organization are seen both in this book and in The Bridegroom Cometh.

The entire structure of sex life and its influence is treated. The emptiness of momen's lives, their lack of emotion, I. Frank, Waldo, The Degth and Birth of David Narkend. The York: Che rles scribner's Sons, 1934), p. 54l-2. 
and their inability to surrender their, own wills are dominant themes. Power, wealth, end the yearning for porer destroys the love life of Americans, ond our men ere weak, insdequate, and unsatisfactory as husbands and lovers.

The pert thet the will of an individual plays in every phase of life is treated in this book, the force and clash of wills and the havoc wrought by failure to subordinate them being shomn. The taint placed upon children who ore born into loveless unions, and the heritege of the child of love receive attention, too. The feilure of modern women to be good mothers and the lock of fulfillment through their children, as well as the failure of man to find satisfoction in sexuel reletions with modern women beceuse she is shollow ond devoid of feeling, is the dominant note. Frank ooes far in his effort to bridge the gap betreen man and the prostitue by means of sympethetic uncerstanding of her wey of life.

Deborah Gore is the mystic and the seeker; Helen larkand seeks fulfillment in the church; Christine Poldiewicz hos complete setisfection in the love of her husband, and hers is the pattern of death in her love-life. Jane Priest, Lida sharon, llarita Fierro, end Deborah are the women who serve; Hester Dwellins, Helen liarkand, and Theodore are those who live for their own satisfection. These, together with the prostitutes, ere the types of women he portrays in this book.

Deborah Gore, through long years of striving, becomes 
a person; David Markand is well on his way to accepting only that which is good and which brings satisfaction; he has discarded the worthless and the useless, and he feels that he is now ready to meet life with love, understanding, and service.

\section{The Bridegroom Cometh (1939)}

The Bridegroom Cometh is the story of two sisters who, born into a lower middle class family in a small town, go to New York to live and fulfill their destiny. It is really the story of llary Donald's spiritual quest; of her search for en integrated identity and for the things that make a person. It is the relating of her struggles and wenderings and searchings to find the rork and the circumstances that will fill satisfectorily her life and the longings of her soul.

The Martha and Mary of Biblical fame are symbolical of the two sisters in this story. From earliest childhood in Marling, Martha and Mary had boen totally different in their outlook on life, in their desires, their ambitions, and their perceptive instincts. Their father was deeply religious, looking elways for the Second Coming of Christ and leaving the relfare of his girls to the uncertain and unsympathetic core of his second wife, their stepmother.

It was Mary who absorbed the greater part of clive Donald's religious teachings; its hopes and fears, its warnings and its promises had entered her soul, and she was 
never eble to renounce them nor loose completely their hold upon her. Sensitive, introspective, and questioning, Mery is indeed a creature of impulses. She is seeking, always seeking, for thet higher life, thet deeper meaning which will satisfy the inmost depths of her being. She yearns, too, to know herself.

She breaks away from home, works her way through college, goes to New York, ond takes up social service work. Unsuccessful at this, she pursues her studies et the University until she meets Willom Taess, a wealthy Jew whom she eventually marries.

She lives with Doris Granes and her husbend, Peter, While she goes to school in Her York. Doris Wes her sociology teacher at Winant, but her ideas were too revolutionery for that respectable college, and she is discharged. Mary had loved her very much and followed her to Ner York. Mary is not happy there nor successful in her job with the children's Frotective society which she secures ofter completing college. In an effort to secure peace end contentment, she marries Willem whom she does not love. She leaves him, goes to clermont to see her blind grandmother, and there her life tangles for a while with those of serah and Luke corne. Her sexual experience with Luke enebles him to start life ggin with sarah.

After leaving there, she has many experiences until she enters the work of the Labor Movement, through the 
influence of Dolg, the Russian organizer. She meets Lida Sheron, whom David Markand had met and liked in Lucy. Mary loves Lida and tries to integrate her life in the Labor organization as Lida has done. This is not possible, however, and she falls back on David Warkand for help. David had returned to his wife only to find an adjustment for lesting happiness impossible; he, too, is seeking fulfillment in his work with the labor people but hes failed to find it; he and Mary, through love for each other, find themselves and true life in their love. We can know that they, as real persons, will love and serve humanity at the same time they are finding happiness with each other.

Martha, on the other hand, takes a business course and works in the mills at harling. She is sultry and passionate, has absorbed none of the religious teachings of her people, and is scornful of restraint. She gives herself wholly and fully to Sid Harvard, and she follows him to New York where she lives only for the deep, allsatisfying love she receives as his wife. Sid, a gangster and bootlegger, is killed, and she, unable to live without him, drowns herself at Loomis Lake where she has gone with kiry to visit her father.

The inability of modern men to satisfy women is an ever-recurring theme, manifested chiefly in Peter Granes and Villem Taess. The desire for power ond his affiliation with the business world, together with his fear of life 
and his inability to break away from his mother, kept willem from living a full life with Mery. Mary, in her search for the meaning of life, sees again and again its futility if one doesn't love deeply. All movements and all works ere unsatisfactory if there is not love as a motivating force. The emptiness of sexual relotions where there is no affinity, and the "raw" deal given women are found in this novel. That a belief in God and the incorporation of the Great Tradition in one's life are necessary for complete integration is emphasized. Children born in hate are tainted, and meny mothers are bad mothers. The author's sympathy for the labor movement is found here also.

Wary Donald Taess is the mystic, and she becomes the full, integrated woman which Waldo Frank believes is essential if we are to abolish choos. Nertha is the antithesis of Mary. Doris Granes seeks for some way out of chaos, but she only plunges deeper into her unrest and emptiness.

\section{Summer Never Ends (1941)}

Summer Never Ends is a record of a man's search for peace and happiness, but it varies greatly from that of David liakand. This story tells of the seeking of a disillusioned husband and father for a secure and satisfactory foothold in a porld that is rapidly disintegrating about him.

Mortimer Crane, a successful Wall street lawyer, is 
giving his mercenary, shallow, worldly wife a divorce when the action of the story begins. He is concerned about the lives of his son and daughter, both born of a loveless union and both groping blindly for what the world has to offer. Leila, his wife, has ruined all their lives. Yet, years ego, he deliberately chose a career that would bring money, pover, and social position to him; in so doing he turned his back on his one big interest, the cause of the laboring class. He deliberotely turned his back, too, on Judith, the strong cheracter, his childhood sweetheart and the moman with iderls, the one who would have givon his life meaning. Now he realizes the shallomess of his existence and the tragedy of his choices.

Danya Petersen, a young college girl, comes to his office to tolk with him in regerd to her thesis, and he snatches at happiness by falling in love with her. Denya is a self-containod, successul, efficient young woman whose father is a radical without a job and whose mother supports him and her son uncomplainingly. Danye's friend and the man she thinks she will marry, is a young Jew, Herbert Stein, who has completed his law course but who doesn't seem to be able to adjust himself to the world and secure a job. He depends upon Danya completely for love, sympathy, and support morally. He lives mith his sisters. He is a decadent character who needs all that a strong woman like Danya can give, but who, even then, would never amount 
to much. Denye pernits herself to be entertained by Wortimer, and she says she can even love him if she vills to do so. She gives herself to him on several occosions in his opertment, but esch attempt at sexuel satisfoction is a failure. Nortimer loves her and feels that he must have her.

lie ruins himself finsncially to give his former vife the alimony she desires and to set his children up independent finencially of either parent. He then decides to take some cases for the Labor people and begin his life again. He goes to see Judith, end she opens his eves to some extent to the course he must pursue. He returns to his chiloren in an effort to bring hormony and peoce in their lives and his by uniting them all in one home. Ferbert kills himself because Crane takes Danya ewey from him, and Danye elone moves on to her ultimate gool, sure of herself and her ability to direct the outcome of her life.

The themes to be found in this lsst novel by waldo Frank are the emptiness of sexual relations that are devoid of love, as is demonstrated by Dagney and crane; that chilcren are poisoned by loveless morriages such es crane's and Leilg's. Judith swift is the roman who serves ond who has found that love is the key to ultimate redemption; Leila is the shellow, self-satisfied woman, and Damey in her peculiar way seeks contentment. Thet men are weak and hove nothing to offer women is brought out well in this nove. The pert 
that will pleys in the relation of men and women is the key note to the reletionship betveen Darney and Crane.

We heve seen Waldo Frank's development as an exponent of certain ideas and as a creative vriter; we have traced his beliefs and opinions regarding modern American women in relotion to his conceptions of society and the universe end have seen how he incorporates these ideos into his treatment of women in his fiction.

Now we shall exemine his presentetion of rodern romen and their problems in more detail. This will be done in terms of his fictionel presentation of:

1. Hodern Women in Reletion to Sex.

2. lodern Women in Relation to larrigge.

3. Wotherhood and Girlhood. 
PART II

CHAPTER I

MODERN WOMEN IN RELATION TO SEX 
MODERN WOMEN IN RELATION TO SEX

The purpose of this chapter is to show the relstion between modern women and sex as presented in Waldo Frank's novele. From his first novel, The Unwelcome Man, to his last one, Summer Never Ends, there is a gradual change of thought, a deepening of the significance of sex, and the adition of sociological and psychological points of view. This growth and expansion in Mr. Frank's conception of the importance of sex relationship fell into four distict petterns. They are as follows:

1. The biological. In this pottern, the ottroctions and desires are purely physical, and sex relations have no greater importence than the mere satisfaction of bio$\operatorname{logical}$ urges.

2. The transcendental. I use this term as it means the resching beyond human experiences into the spiritus.l, mystical, and superphysical. Whis sex pattern calls for more than the physical act, for Mr. Frank integrates it with mystical experiences thet lift it beyond the scope possible in the first pettern. There is also conteined in this a justification extending even to the prostitute. It is here that he finds an artistic treatment for the sexual act. 
3. The social-psychological. This pattern emphasizes the emptiness and frustration of sexual experiences where there is no love, and the lack of both love and deep feeling in the restless, lonely women of today. Mr. Frank now attacks the problem from both a sociological and psychological point of view, giving serious consideretion to sex relations as a universal, all-embracing problem which confronts every human being.

4. The personal. The fourth pattern interprets the universal problem in terms of the individual or the person. None of the wide scope of the third pattern is sacrificed, but, rather, it is intensified as he now translates the experiences into the life of the person or the individual.

There is a relationship between these four patterns of sex behavior and the four periods to which his literary works belong which will apper more fully in the analysis of each sex pettern.

1. The biological sex pettern is to be found in the books, The Unwelcome lan and Dark Mother, both of which Were written during the experimental stago.

2. The transcendental sex pattern is to be found in Rahab and Holiday and in the collection of short stories, City BIock. These books ere the outstanding examples of his work during the aesthetic period.

3. The social psychological sex pattern is developed thoroughly in The Death and Birth of Devid Markand, 
the book that is the outgrowth of the period of social consciousness.

4. The persongl sex pettern is typified in Summer Never Ends and The Bridegroom Cometh. The latter deals with marriage particularly, and the sex problem as sumes importance rarely except in relation to marriage. Since thet problem will be considered in another chapter, I shall make only a passing reference to the meterial in The Bridegroom Cometh.

\section{The Biological}

Sex relations have no greater importance than the biological one in the books, The Unwelcome Man and Dark Mother. Neither the significance attached to the act nor the reactions are ever deeper than physical disturbances. Quincy Burt's experience with Judith Deering is the sole treatment of sexual relations in Unwelcome Man. There is a mere mention of such experiences on the pert of Quincy, but it is no more than a suggestion. Even Judith's actual feelings are never directly analyzed, neither before the act nor afterward. It assumes no greater importance for her than the ettraction that an older woman often feels for an unsophisticated boy when she finds herself lonely, or when she has the desire to feel that she has helped him in some way to be a better person. Quincy was not equal to carrying on the affair, and it ended with the one night they 
spent at the hotel. Even this meoting is not described in any detail, and, compared with the sensate descriptions one finds in Hr. Frank's later works, it is of little or no importance. It is true that quincy suffers terribly that fall and eventually quits school, but the sexurl act itself did not couse these disturbances; it was Quincy's nature that coused him to tangle this affair with his love for Judith's husband and his own acturl comardice.

Several sexual experiences are recorded in Dark Mother, but they, too, are the satisfying of desires, and even the physical aspects ere dismissed lightly. Tom Rennard and David Markand have intimacies with women, but these are broken off at will with no one experiencing more than a passing feoling of pain.

Marcia Duffield suffers considerably when Tom ends their affair summarily, but the fact that she plans to marry unwisely and without love cannot be said to be an absolute outgrowth of the affeir, for, in her circumstances, such a marrige would have been planned anyhow.

David Markend and Anne, the eervant girl, left alone in the Deane home for a few weeks one summer, satisfy their physical cravings when she slips into his room at night, but after several such experiences, she withdraws, as a good servent should, and it is never mentioned by either one again. A few sentences suffice for putting the intimacy in its place: 
But the heat did not stop: nor the wearing away of will and the rebellion of nerves. Anne came again. It hed nothing to do with the wide remainder of their lives. It was somnambular.

All one week, Anne's step on the threshold of his room was gone. David fumbled in bare feet along the tunneled hall. His flat palm felt her door. It was locked. The end-sweet end of unreplenishment. No word further: no glance toward the past to open it once more.l

Lois, his cousin, liked to play around with the idea of loving David, and he thought he loved her, but she never gave anything but a few kisses, and David felt that she was too young to know passion.

This calm acceptance of sexual relations can last but a short time, however. Mr. Frank himself grows beyond that, and his own sympathetic probings into human lives and his expanding arareness of the problems of women netura.11y lead him into deeper analysis of the problems of sex. This can be seen readily enough in his works of the next period.

\section{The Transcendental}

From the pattern of pure physical satisfaction which he presents in his experimental stage, ins. Frank now turns to problems of greater significance. The artistic treatment 1. Frank, Wa1do, $\frac{\text { Dark }}{1920)} \frac{\text { Hother, (New York, Boni and Liveright, }}{\text { pp. }}$ 
of $s \theta x$ in this transcendental manner suggests that the author is trying to free himself from something repulsive in the sex relationship by translating it into the highly aesthetic langugge of mystical realism. There is also an indication that Mr. Frank is trying to bridge the gap between men and prostitutes by presenting the latter in the most humane light possible in Rahab; he tries to span the gap between negro and white in Holiday.

\section{Rahab}

There are two themes developed in the presentation of the sex problems in Rahob. The first is this: If we are to live richly and abundantly, we must have a sympathetic understanding of people and a love for them; these tro characteristics will transfigure even the life of the prostitute. The second theme is the clear conviction that God has a place for each of us to fill and a task for us to perform, and it is our business to search until we find it.

Rahab is the story of Mrs. Luve who becomes a "madam" presiding over a house of prostitution. Her mystical experiences, her talks with God, and the gigantic struggle to bring her life into line with what God would have, give us a new light on the life of a prostitute. We are even willing for, her Bible to be her most intimate companion in such surroundings and experience no feeling of 
sacrilege that it is so. It is in such a setting that we meet and come to know well four of the girls who are prostitutes. Mr. Frank tells us those things about each girl which win our sympathy before we are arare of the fact that they are prostitutes. Each one of them has had that in her life which not only has forced her into this way of living, but which, when we see it through the loving, understanding eyes of ifrs. Luve, creates a sympathy for the girl and causes us to look less severely on her. The harshness of life and of society or the cruelty of fate has forced her to sell herself, and one can do nothing but condone her life and wish her well.

Clara Lonergan worked in the same office with Mrs. Luve. She was not hoppy; she was restless, tired; her parents had been unhappy foreigners, and her home was something she could not want to remember. When Fanny saw her, Clara's eyes were "very black, very lerge, dry and within themselves like windows of some hidden world having no faith in the sun."I

Then, when Fanny Luve wes down ond out, ill and penniless, it is clora who waits on her, brings the doctor, buys the medicine, and moves her into her own apartment so she can care for her better. Clara and Fanny love each I. Frank, Waldo, $\frac{\text { Rahab, (New York, Boni and Liveright, }}{1922), p .89 .}$ 
other, and it is the tenderness that Clara has for Mrs. Luve that makes us viling to love her, even when we learn she is a "kept" woman.

Tessie Liebovitz and Susan Sennister come to see Mirs. Luve before we learn what they are, and Tessie's story makes us willing to eccept her and eay "Bravo!" to her, no matter what her life may be. Her Jewish father had sacrificed all he held dear to send Tessie to New York to take violin lessons. She was told that her fingers were too short, and some doctor offered to stretch them, and, in so doing, broke them and ruined all her chances for a musical career. She had to send her old father money, and she took the easy way.

Susan was warped and twisted and hard - life had made her so. One feels sorry for her as she says:

$$
\begin{aligned}
& \text { "I believe in the power of Hate, } \\
& \text { I believe in the truth of Sin. } \\
& \text { I believe in the failure of Truth." I }
\end{aligned}
$$

Thelme is the girl who stays with Mrs. Luve when the Law steps in and closes her house; Thelme rents onother place and gives to Mrs. Luve the kindest treatment possible and sees that she has the best of everything.

There is a great amount of good in each of them; much to admire.

Mrs. Luve, of course, is the central figure. Driven from her home and her baby because of one sin, she seeks 
always to know the truth about God and Christ. She comes to realize at last that God is near and that He has a purpose in life for her. She says:

"When I came to New York, my coming meant one thing. . . All my life was a hideous jest unless my coming to New York meant one meaning."

"Whet was that meaning?"

where you are." 1 ,

"Wet was that meaning?"

When she was ill and penniless and almost dying, she

cries hysterically:

"God! You aren't much for me. But I believe in you. Do you hegr? Even now. I am not rotten, God. I heve done wrong, God. You must hear me, for I believe in you, somehow, my Father. . . I am leaving the world. But I have been a pert. I believe that, God. I have been a part and you need all parts. You have needed me, God? . • "Say you have needed me, God for a pert something. Whatever it is. You've done with me now. But you've used me. Haven't you used me, God? You're casting me in the ash-heap I know. Can't you say at least 'Thank you' before I am gone?" 2

After she has been for some time with the prostitutes,

she seemed to have them cleer.

These men and women were no accident. They had words now she understood. They had wills now - here was the wonder of her life that touched her own. Not Harry's will had touched hers. Not her child's, to eat her's up. Not christopher Johns'. And Leon's... Leon's will had stood beyond her, over the ken of her horizons.

These wills touched hers! - these wills of women disgraced, of men criminal and broken, outlawed and dissolute. 3

1. Rahab, p. 123 .

2. Frank, Waldo, op.cit., pp. 158-9.

3. Ibid., p. 219 . 
She came to feel that she had come to New York just to be with these lives. The House which she ran became a reality, the one success on her tree of failures, and she gave herself wholly to the House. She did not judge them the prostitutes, the gamblers, the lewbreakers who came there - she understood them and loved them.

Thet is why, years later, when samson Brenner sees her, there are "centers of glow, thrown from the woman, solid like her spirit. He was aware of loveliness." 1

(Again) She seemed a chaste woman with burnt eyes. He could not help seoing her, seoing her more and more. Prail slain fingers resting upon a table warmer then her hand. She all a. sapling broken in frost.. - standing seasons dead.

When she had accepted the last one of them and had loved them through understanding, it is no wonder that "from the wreckage of her features there was born a smile making them clear and sharp, making them fair and high. A Light shone in them". 3

\section{Holiday}

The sexugl hunger of John Cloud, the tall, stalwart, proud young negro living in Black Nazareth, for the lonely, rebellious white girl, Virginio Hade, of White Nazareth,

I. Frank, Waldo,
2. Ibid., pp. $15-17$.
3. Ibid., p. p. 250.


will offend the prejudices of many readers, but the sex problem transcends, somehow, the race problem between black and white, and becomes an elemental thing, larger than either the white girl or the negro boy.

The town seethes in the hatred of white for the blacks. The chaos of the town enters Virginia Hade. Tre see her first:

She walks domn the aisle. The grace of her strong way is broken by a strain vising her hips and her dark eyes that meet the gleam of the candelabra. She is tall and firm, but her harmony is broken and her eyes are not happy.1

She cannot sleep when she goes to bed. She thinks - I am efraid of sleep. Thet's why my eyelids tremble and burn; thet's why my hands hold rigid on my brow.

Thrust out your arms. That's right. Lie all stretched out. There is a poison in your body, and it lurks in knots. lingers.

If you draw in your leg, the poison

If you cradle your fece upon your elbot, so...

Your lips close to your breast... The poison lingers. be clesn.

Stretch out clear like a rod. Then you'll

o I want to go to slegp, I am wery.

o I wont to wake up.

She goes on to call the night a "raping nigger"; the dream world is a Nigger too; the vorld is a dark flame; her insides are dark. Then she muses that perhaps death

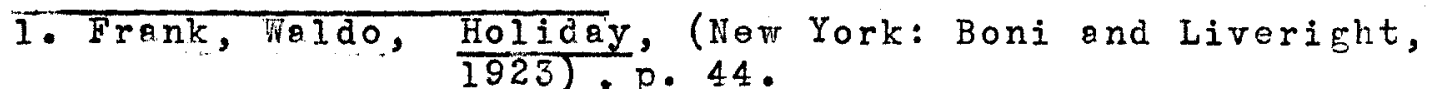
2. Ibid., pp. 64-65. 
is white; perhaps her soul is white. Then, again:

- O I'm unhappy. That's why I

can't sleep.

O I thresh about a.1I day in strew

- dry, dry. .

- I wrestle nights against dark forms of my soul

Breaking upon the dry white of my breast

Saying No. saying No.

- My soul's not white!

Death's white: my soul wants to live.

It cries to live;

It sings to live,

It stirs within me like an unborn babe,

bleeding to live, all bloddy with my blood?.

And my white breast says No.

- Why does the world say No?

Why don't I dare to learn how to say
Yes?

John cloud's mother senses his longing, and she is

afraid of the look in his eyes. She wants him to marry the negro girl, Mary Cartier, who loves him. Even though he decides to do so, "he longs away".

His body lies prone and sweetly wakeful within the megic of his folk. Yet part of him is uncovered, longs beyond: no glowing blanket of his folk can touch it.

He thinks:

- There's a white dream stands between my mouth and Mary's

A white sunbeam in my soul.

I'll climb it. Tha's what it's fo'? I'll

vault with the white sunbeam!

Empty pale world - world of the Free,

Wait till I come an warm you: woit till I

come an' fill you.

- Mary, the world is proud: world's a white

T. Frank, Faldo, Holiday, pp. 69-70. 


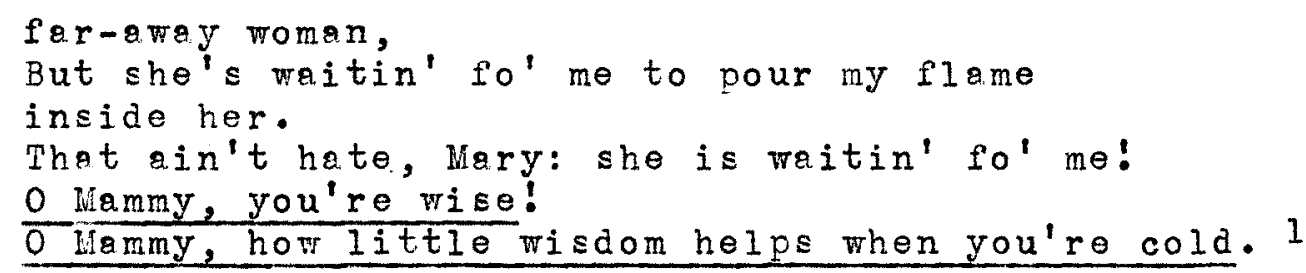

Inevitably, these tro sex-hunger souls are drawn together. It is a half-holiday, and he goes along a stream to the land's high edge - s wooded knoll near a deep pool in the stream. He dives in the cool water for a swim. Virginia Hade goes to that same place. Mary Cartier, watching, questioning, says

\section{- Why?}

He went that way,

What moved him?

She went that way,

What moves her?

$\mathrm{He}$ and she

And $I$

An' the slidin' sun

And Nazareth risin' risin'
Risin' flame?

When John comes out of the water, he sees Virginia sitting there, quietly, waiting. As they talk together, 8. Wram bond draws them close, throbs tensely, moves them nearer together. Then, at her suggestion, they rise to exchenge knives, and his hand touches her - - their bocios are close.

But still her body is beyond his clasp: he is possessed by it, he cannot grasp it. Within his eyes her body's moving form invade him. He is trenefixed, he is displaced and

I. Frank, Waldo, op.cit., p. 62 . 2. Ibid., p. $15 \overline{3}$. 
wracked and marvelously broken. . filled with this sweet unbeareble trample of her flesh within his breast, within his heart and loins. - I am John Cloud. John Cloud! His hand drops hers. Both of his hands fall limp. "Will you exchange?" she whispers. In her voice, the voices of many wille collide to silence. For a moment she is his creature there: a sterile moment. For he obeys her: takes her knife, gives her his own crude blade. Above the knives is darkness. He seeks to see her. I am John Cloud. Nigger. 1

And, as he sees her features, drawn and hard, he walks away. Virginia, left alone, weeps and pities herself. Whether it is the frustration of her desires which John deliberately refuses to satisfy, denying both himself and her; or whether it is her desire to overcome the loathing she feels for herself becouse she has wanted a negro; or whether she hopes to stamp out forever the burning desires which torment her soul; or whether it is a mixture of all these, - - she turns John over to the mob. As they hang hin for daring to look at a white girl, Virginia finally sleeps.

This pottern incorporates the sex desire thet can only bring death, and Waldo Frank presents it again in the case of Martha and Sid in The Bridegroom Cometh - a sex hunger that can end in nothing but death. There is also in this case a deliberate betrayal of the man for whom the girl feels a yearning. The trogic frustration in 
this instance hes deep significance that takes on the element of the psychologicel and the sociological. It points the way to the embracing of the sexual relationship 2s a universal problem, wider in scope than the artistically transcendental treatment given it in this period.

\section{The Social-psychological}

The sociel-psychological pattern of sexual experience becomes universal as it is presented in The Degth and Birth of David Markand. The sympathy and understanding with Which Mr. Fronk portrays the prostitutes in the transcendental pattern are emphosized in this period, also, for the story which the author tells about each girl permits us to see her in a kinder light; and knowing her personally takes a Fay all condemnetion.

Lois Pollard is pitiful in her loneliness and lovelessness. She is not needed by anyone, and she is seeking something with which to fill her life. Betty Milgrim, frank, honest, and young, comes from a small ohio town. Her mother worked in a mill until she took sick, and Betty manicured nails in a barber shop until she saved enough money to come to New York. She yearns for financial security and the day when she can afford to get fat. Lucy, revengeful like Virginia Hade when her passions know frustration, is motherless, and her fother gives her nothing but those things which destroy her. She is restless, 
wilful, and unhappy. Irene's parents were of the lowest class, and when she sees what a hard time her mother was having as good woman, she left home to become a bad one. She has never had a chance to be anything better. Theodora Lenck's life has been empty, and one feels sorry for her because she has never had a man who could satisfy her, or bring to light her latent possibilities. Jane Priest's terrible experience when her step-father tried to become intimate with her leaves us wishing her any sort of happiness.

In addition to the incorporating of the transcendental characteristics, there is the added emphasis on the emptiness of the sexual act and the ultimate frustration when there is no love. The frailty and shallowness of modern women is the main theme of this pettern. That there are sociological reasons for this condition may be seen from the stories told above.

David Markand's sexual experience with Lois was a failure. "Her breasts were weak and limp, her body was wan like a flower too long out of the sun.." and "Her body touching his was soft, frail, strengthless, bringing pity." I

The consequences of this act and of her entire way of living may be seen from their conversation some weeks later. She says:

I. Frank, Waldo, The Death ond Birth of David Markand, 


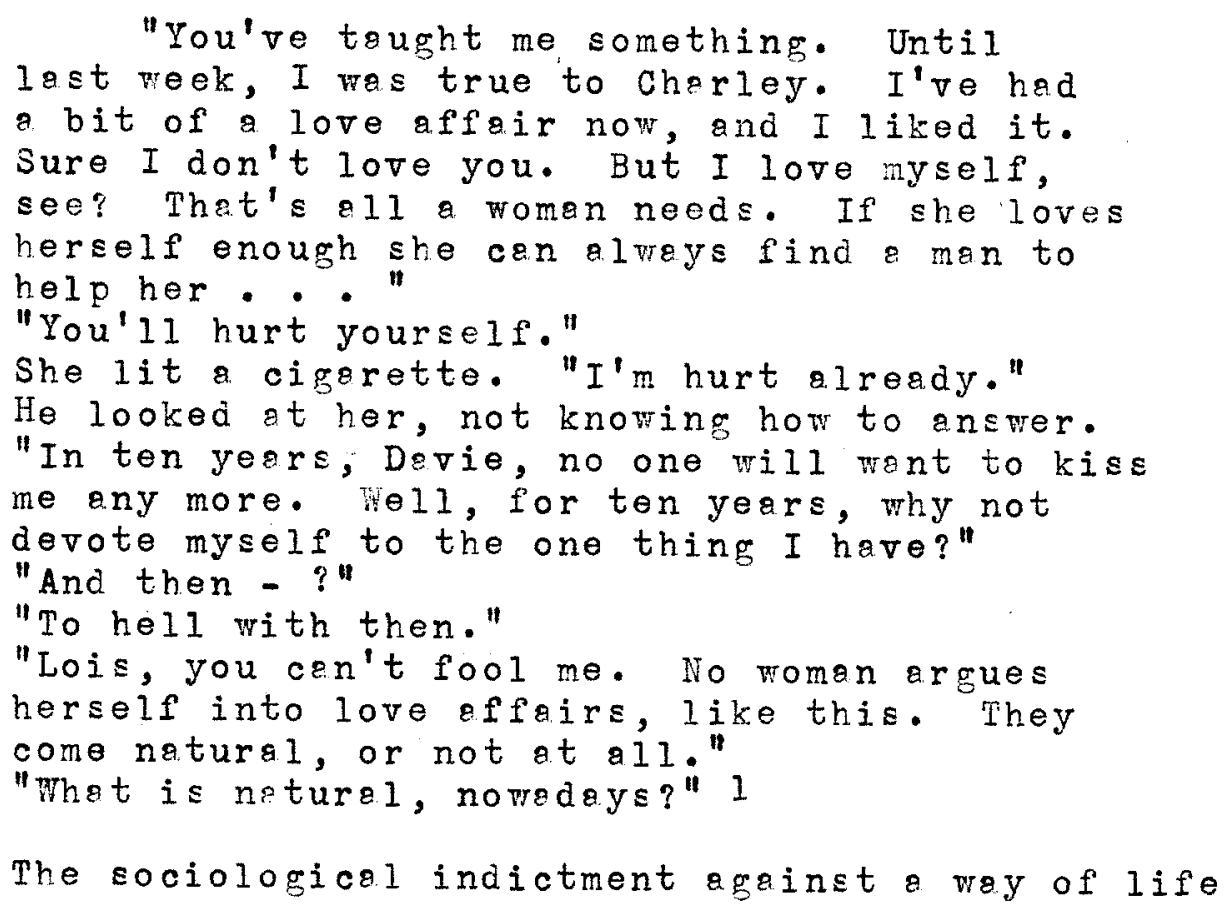

thet permits such a fine, rich young woman to come to this state is strong and unmistakable.

His attempted intercourse with Betty lilgrim goos wrong when he kisses her. "Her lips tasted frail, girlish, passionless. . its taste had cooled him. can one lie with a woman, he asked himself, without kissing her mouth?" 2 As he was about to leave, "He stood silent, and he saw her. Not the vague summons of his own desire; he saw the objective creature. - near." 3 The pictures of her herd life and her struggles came to him, and he simply could not take her. He tried to onalyze his feelings after he hed reached home. He only knew that "life that had I. Frank, Waldo, The Death and Birth of David Markand, p.66.
2. Ibid., p. 72.
3. Ibid., p. 72 . 
been strange and far away had suddenly been strange and

near. Intolerable. He had run oway from the girl's intolerable neerness." I Then the solution comes:

- And where is the need gone? His body has no hunger. Something has changed. The cold water as he took a shower. - he feels close to it, close to the street floating in globules of sound through the open window, - Is nearness to life a substitute, which he has somehow won, for nearness to the body of a young woman? He knows what he is going to do: That is nearness

Thus from his sexual experience arises feolings that are universal in meaning.

When Markand would have taken that which Lucy Demarest offered, he was repelled by the touch of her breasts. "There was something in them woak and infirm . . . : the deficiency was of the woman". - "He touched her throat with his mouth. . the same sense of shallow frailty stopped his passion." 3

Then there was Irene in Kansas. He knew his desire to be thrust against "the emptiness of this woman." He says she was "emptiness incarnate". 4

By her hend he knew her. Weakness. Pitiful will of a child to live and to have pleasure. Bravery of brown suit, bravado of her laughter; the stifling of her senses, almost in birth, by her will, in order to get

1. Frank, Waldo, The Death and Birth of Devid Markand, p. 76. 2. Ibid., pp. 76-7.

3. Ibid., p. 163 .

4. Ibid., p. 209 . 
dollars, dollers. He was revolted, not by the child-hand but by its clutching the bill. He wes moved too violently from his nossion to feel oity. I

Irene, in order to do her business mell, never permitted herself to feel ot oll; she remained possionless. Ferkend decided that he must see her again and arouse some shot of possion and feeling in her. This he does, quite skillfully. Snerling curses et him, she leaves, filled with hate for the man who groused her. Thinking over the damnoble port he hod ployed, he said to himself:

You vanted to meke her feel, you lusted to make her feel. Just to take her and use her, passively, as she consents to be used, Wes not enouch. You had to trick her into feeling. And whet if her solvation, playine this game of hers, is to feel nothing? You didn't think of that. Shremly you pleyed on the child, broke her defenses, roused her, shottered her. She felt in the end - whet? Your will. 2

Yis life with Theodors Lenck berins with the urge to setisfy their physicel desires, and tris they do, impersonally, for some time. Theodora soon yearns for more than that, hovever. She berins to feel dissatisfaction.

All else, even his coming close end his heeding the subtle hungers of her body, was her will and her action. And she was lesrning that the soul of her will wes not to want of him, but thet he should want and use her by his own lew. Since he mas elways hers, she wos not his, and so she did not hove him. Since

1. Frank, Faldo, The Death and Birth of Devid Mrrkand, p.209. 2. Frank, waldo, op.cit., pp. 225-6. 
he moved es she willed, she did not move him. Only when he swam alone was he moving of himself. . in the cold weter thet somehow was the world and was between them. 1

Theodora could never surrender her will, however. Perhaps the fear created in her at the thought of surrendering her old life; perhaps it was the lack of love. Markand feels this struggle in her.

In loneliness, and in pity, he holds her hand: pity for her who seems so childlike, spreeds to enclose him also. Will it remein alwrys pity? Might not self-pity turn to fear, and make him rend her? He sees her body which con be so passionate and certein: body of the thrust of her will. . . leaving her behind, childlike and bereft in the shadows. Fis will has won her nothing, save to make her vulnerable, and to vard off from her his love which she alone desires. 2

She yearned for his love more and more, and, as the months passed, vrith no lessening of their pession, she found thet it no longer fulfilled her nor relessed her. She grew tired. He ressons out their reletionship in terms of her will:

He knows now why he and Theodora Lenck have lived togetrer: the passionate conspiratorial geme they have played so hermonious together, he for his own end, she for hers. Through her, he hopes to re-incorporate himself in the world, in the person, of the old David Harkand. - Ted? She mants me to save her, through love, from her omn will: but in terms of her will! in the same damned world of her will: She wants her hevven without giving up a spot of her beloved hell. We are accomplices each of each. 3

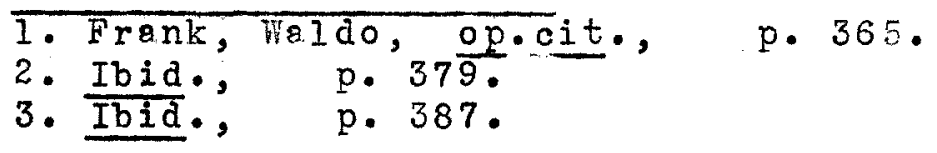


There comes the time when Ted knows that sho cannot live without the loving of this man and yet she can no longer accept what he gives. He tells her:

"You want to separate us from everything in the world. That's your idea of love. I can't do it. You know I care for you; I care for you now more then I ever did. But I've never felt our relationship could be seperate from the world; which would mean that $I$, personally, could be seporate from the world..... For you can't be alone, Ted, there is no being alone - not even with a lover." I

Inevitably, "she wos alone, now, with her will to be loved wholly, to possess him wholly. And her will, deprived, turned on her; it was cold, it was loneliness itself: end rent her". 2 Because neither of them loves the other enough, the offoir must end in tragic frustration. Ted, seeking surcease from her sorrow and loneliness, tekes an overdose of sleeping powder when she finds that feme in Hollywood is empty of comfort, too.

Again, a whole way of life is responsible for the tragedy. I shall not attempt to analyze this affair psychologically, for that is not my tosk, but there is a wealth of material in this one sexual offair and its comlications - enough, I should think, to keop a psychologist busi for some time.

Seeing the sexual problem as a universal pettern, Waldo Frank now gives us two other experiences that are entirely different. Lida Sharon is the social worker who 1. Frank, Faldo, op.cit, , p. 399 . 2. Ibid., p. 405 . 
has given up her entire personal life to carry on her work. She is not remarkable in strong sexual feeling, and she accepts her work in the lobor movement as a substitute, only to find that it doesn't fulfill her. This conversation between her and David illustrates my point:

"I don't find you pretty, Lida, thot's a fact. And I don't mind teliing you, a bit; for I'm sure plenty of men do find you more than pretty."

"You're clever. And you're liar. You know I'm not attractive to men."

"How should I know that? I don't beliere -" "Well, it's true, David."

"Does it hurt?"

"It hurts like hell. But what of it?" I

At another time, as they talk of work in the labor movement, David says, "Lida, there've been times when I felt sorry for you. Beceuse I didn't find you physically pretty. I was a demn fool, then. I'm not sorry for you. You are happy." 2

Whet on analysis of their problem is here!

He sat on the bed, and touched the heir of Lide thet shone like black fleme in the luminous night. He was et ease with her so, and she ith him: she wanted no other than his hond's light touch on her hair. Then lorkend knew that sex, os men gave it form, could be a lie: what was this between them, but a continuing of his impersonal union, and of hers, with the dark earth singing? He could not give it other, truer form. And this, Lida knew. If he now touched her sexulliy, he would herm her. Women are wise, he thought. They know when the sexual embrace is truth, the soletruth. . and when it is false. Ted. knew. This quiet pause with Lida is whole, and 
she accepts it. With Ted so mucr more,

and yet, since it wes not whole, so

desperate little! Why should I not give

Ted what she could accept? Because I could

not, she hed to die. Becruse she was destined

to die, I could not wholly join her. 1

Jane Priest is the girl whose stepfather attempts to

force her into the sexual act with him, end warkand and

John Byrne find her as she is attempting to run away. They

toke her glong, and she and Byrne, working together in the

labor morement, come to love esch other. They live together

for months without the benefit of a marriege ceremony, and

they are very happy. Horkend, watching, "knew the quelity

of Jane in her intimate life with Byrne, how in their em-

brace the balence to Byrne's dominance was struck: she then

was dominent, his was the ecstecy of surrender." 2 she

believed in God end that He was in all things, and nothins

could shoke her in this belief.

They vere heppy. - Jane, to her man,

hec the sevor of the eerth's fruit; Byrne to Jane

Friest was the earth's iron and fuel and straight

pine, made by the God in whom she still believed

to be a men and to walk among men and to lead them

to the benison of fulfillment.

Larkend watched them as the months possed. Byrne,

"from all his journeys end conferences, ceme back, tender, to Jane." 4

The bocy of Jene, when they irirst found

her, wes sultry hot, as if it hed lived sunless

and breethless: now, beneath her poor clothes,

it had a quet fervor. She had seemed, with

\begin{tabular}{|c|c|}
\hline $\begin{array}{l}\text { 1. Irenk, } \\
\text { 2. Ibid., } \\
\text { 3. Ibid., } \\
\text { 4. Ibid. }\end{array}$ & $\begin{array}{l}\text { p. } 4 \frac{o p}{64} \cdot \text { cit. } \\
\text { p. } 469-70 \\
\text { p. } 477\end{array}$ \\
\hline
\end{tabular}


her stoop, flat-chested; now her head held high revealed her breasts tenderly and proudly. Her eyes like Byrnes's were the color of dawn; but they had softened and deepened with this gladnese of her body. Byrne too hed changed; he was less tense, more boyish; the grimness of his mouth had ripened into repose. There res a current alternant between these two; and it was impossible to say with whose strength Byrne worked eighteon hours at a stretch, conferring with stubborn Irish and inarticulate Slevs; or with whose vision Jane returned from her drudgery at night to become a roman delicate and watchful. I

The sexual life, giving complete fulfillment, has love - deep love from the man for the women and from her for him. They are both busy doing the rork wich they love and which they feol they were destined to do; she believes in God and in His direction. They have much in common, both in mind and in spirit, to give body and soul to their sexual life. These things, then, bring fulfillment.

\section{The Personal Pattern}

The sexual pettern in Summer Never Ends focuses sharply on the individual, Dagney Petersen, and the man who wishes to become her lover and husband, Mortimer crane. All the themes of the other petterns are touched in this book, but the experiences of these two form the sole besis for the plot of the notel. The part that will pleys in sexual acts is emphosized here, as it was in the affeir between Theodora and David; the emptines of modern women and the frustretion

I. Frank, Waldo, op.cit., pp. 477-8. 
from lack of love are important also.

The lovelessness of modern 1 ife is the note sounded early in the novel when Hortimer Crane and his son are talking. Crane has just asked Somerset what he knows about what girls want. The boy's answer is:

love that."

"We11, I know how to hate the bitches. They

"How do you express your hate?"

Somerset joined his hands behind his neck and laughed in his father's face. "That's not so easy to tell, old man. It's called making love."

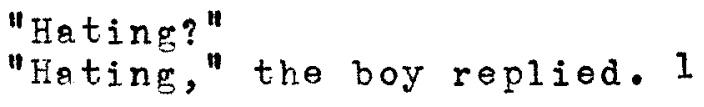

"Hating," the boy replied. 1

Degney had been going with an unfortunete youth, a lew student, for some time. She felt sorry for him and wented to be kind to him, knowing that she was all he had that he cared for. When Crane tells her she does not love Herbert or she could not enjoy his caresses, she answers, "Then I will love him. I'll learn to."

He then a sk her to swear by her mother that she loves Herbert. She answers, "If I choose to love him, I shall love him."

When passion draws them closely together in a long embrace, Mortimer asks, "What you felt in my arms doesn't count?"

She replies, "Not if I choose."

When he asks her if she was ever moved that way when Herbert kissed her, she told him that she was not. "But end Pearce, 194I), p. 45. 
it's unimportant?" he asks.

"If I choose." I

She permits Herbert to kiss her, too. Two of these

times are described:

He kissed her. She did not return his

gentle pressure on her lips; possive, she permitted him to drink the life he needed.

And when he moved away, again to see her,

there she wes, cool, observing him.

He took her in his arms, holding close

to his body the slenderness of her shoulders,

and on his mouth her mouth thet did not resist,

that slumbered, and that told him nothing.

This same possiveness and calm acceptance are seen

when Herbert asks her to go some place with him and spend the night. She felt his crying need to be close to her, end her one answer wes, "Come." When he can find no room suitable for her for the price he can pay, she accepts that colmly, too.

"Why," Herbert said, "did you come along when I wanted to take you to a room? Why did you come away so easily, when I said No: it was too horrible? You didn't care, one way or another. You are horrible."

"Whet should I heve done?"

"Care!" he cried. "Care to do something enough to strise for it? Care not to do

something - enough to fight against it." 3

She says that she does not believe in God; moreover, she has told Herbert she mill marry him, but she has no intention of doing so unless he fails to succeed. In that case, she will marry him to help take care of him, but the

1. Frank, Weldo, op.cit., pp. 104-5.

2. Ibid., p.67\% 
fact that she doesn't love him would not matter.

When Mortimer makes love to her, she responds readily

enough, but she firhts for a long time ageinst furthor

intimscy.

He knew he could not really make her out. She seemed to him a virgin, and yet not a virgin; her eyes were distant and cool, her mouth was close and warm; she was submissive ond she had a will of her own; her body, when he held her, was wonderfully his, and at that moment, evaded him. But whatever she was, bound him; there was no contradiction in her that did not weave the bond. He knew he did not know her; and he knew he must. Imperceptibly, treacherously, his will hed come into his pession. At the end of the deep, final embrace, he will know. - I won't touch her till she knows it is important! But she knew: he saw her mouth faintly parted in what might be the beginning of an outcry against hurt, against fear. And resolving not to touch her again, he touched her. 1

When she does, at last permit the sexual intercourse, he knows complete frustrotion, for sho is a sudden deadness -- great obyss - complete emptiness. A second time

the same thing occurred.

At that instent, crane knew not only what he must do; he knew what he was going to do, and what would come of it. He hoted himself because of it. He hated her because of the abyss in her which lost him. He was full of hete, and he knew it: his possion and his delight were swollen with hate as a tumor with black blood. This was loveliness, he knew as he took it, and it was heteful. 2

Studying over the unhappy affair,

Crane sow that there rengined a finsl act for his death. He would hove to finish off his

I. Frank, Waldo, op.cit., p. 102.
2. Ibid., p. $29 \frac{\text { p. }}{4}$ p. 
dying, as hote had finished off the love between him and Dagney. Hate. There was the secret! there wos the source of the poin! He heard his son on the Huntington terrace: I hate the bitches. - meaning he made love to them. - If I had acted differently when she was here and in my power, perhaps she would have loved me; perhaps at that she loved me better than I loved her. Hate crotrded her out. Where in my life has there been room for love? Had he lived . . and all of them . . lives where alone hate could live? Did hete bring together the bodies of lovers? did hote bear the children? 1

Judith, the woman whom he loved as a boy, hears the story of Dagney from Mortimer.

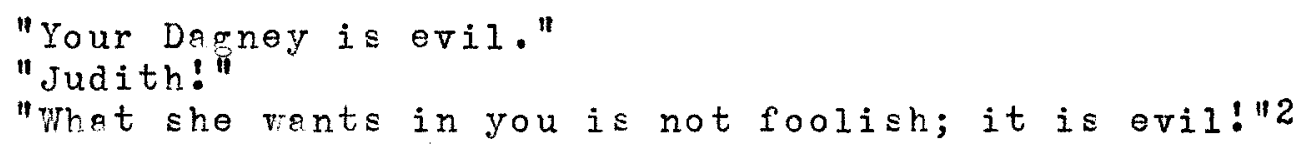

"She loves your confusion; probably also thet Jewish boy's confusion. I con't blame her. Whet else have you men got for women nowadays? Perheps she'll get overit. If she ever meets a man that's clear." 4

\section{Conclusion}

Women and sex: hr Frankls conclusions are clear. He has definitely estoblished the fact that sexual relations

1. Frank, Waldo, op.cit., p. 199.
2. Ibid., p. 199.
3. Ibid., p. 200.
4. Ibid., p. 200.


without love have very little if any satisfaction. Furthermore, these relations have more meaning and significance than the mere physical act. He has a genuine desire to lend people to see the circumstences which more often than not force prostitutes into the business--at least, he himself has a deep understanding of them that transcends ell blame and censure.

Modern women are empty and shnllow unless they have become a person - as Jane priest. They need sexual relotions, and nothing else quite tokes the plece of thet. He pleces much of the blame of women being as they are squarely on the shoulders of the men. They just heven't much that's wortrphile to give to women - sureness, love, stebility, or uncerstandino.

Lastly, combining the tronscencentel, the socielpsychologicel, and the personal, there is the belief that God is in $u s$ all and thet He hos o ploce in our heorts and lives. He sums this up in a letter which he wrote me on January 28 :

God is in every man - every self. Thet I know with an immediate certainty that has no equal. And I do try, in my poor bungling way, to reglize, as I telk with my brothers and my sisters, and os I look out on the historic scene, that GOD IS in them all. It is a frightful porodox; snd the sole threshold to truth. 
PA RT II

CHAPTER II

THE TREATIENT OF WOHEN IN RELATION TO MARRIAGE 
THE TREATMENT OF WOMEN IN RELATION TO MARRIAGE

This chapter is an analysis of modern marriage as presented by Waldo Frank, the emphasis being placed on a study of the porticular problems of the morried women in the novels. The analysis proper is preceded by e brief sketch of the pertinent background.

\section{Background}

Waldo Frank has had an opportunity, beceuse of years of living in and treveling through all European countries, South America, and the United States, to study widely and deeply this human reletionship of marriage in 011 its complexities and varying aspects. That he has definite beliefs and principles concerning all Americen life, acquired from years of intensive study and keen observetion, was set forth in the second chepter of Part $I$. Working honestly and sensitively and with continuous vision upon life, he has shuttled bock and forth between an anglysis of social aspects and the using of his conclusions in his fiction.

The best embodiment in fiction of his conception of marriage is found in The Bridegroom Cometh. It was written after he hed reached the full years of his experience ond can be considered os 2 most mature piece of work. His idea for this story had its origin in the fact that his second wife, Alma, ceme from Manchester, New Hempshire, which is just 
the sort of mill town that he has given us in liarling. She had known how the mill workers lived and some of the problems they had to face. Mr. Frank's conception of Kary Donald was, in its initial stages, that of his wife. As he gathered his factual materials in Manchester, however, and as his other characters and the plot took shape, Mary grew away from his wife and became an individual in her own right, far different from what he had originally conceived her to be. She became a person, totally unlike anyone he has ever known.

The problems confronting modern merried women are presented in The Bridegroom Cometh from women's perspective; they are primarily those of women; in the attempts at solving the difficulties and stablizing relotionships, we are concerned chiefly with the women - their actions and reactions.

For comparisons and for different points of view, I shall use the marriages in City Block, Death and Birth of David Markand, and some references to Summer Never Ends. The stories in City Block ore included for three rossons: it is one of his earliest works dealing lucidy and carefully with marriage; the stories are told impersonally, as if the author were just taking a peek into the lives of these people, the book being written quite objectively; and, thirdly, the themes running through some of these marriages not only forecast his ideas regarding our society 
and marriage, but they are the very themes which are developed more minutely and thoroughly in depicting the success or failure of this relationship as he portrays it in his later books.

Much of the factual material in City Block was obtained during the year in which Mr. Frank lived on an East side block in New York City. People he met and observed at that time gave him the nucleus for some of his ideas, plots, and characters which are found in the stories.

In The Death and Birth of David Markand, the central figure is David, and all the events are more or less subordinated to him; they are seen from a man's point of $\nabla$ iew, or they are presented in their relationship to his actions. The marrigges which have been discussed at any length, therefore, are seen from a man's perspective.

One marriage in Summer Never. Ends has been dissolved before the story opens, and the reader looks on while the husband completes arrangements for the divorce; the other marriage is not between principal characters. These two, therefore, can be viewed objectively.

Since Haldo Frank's marriages may be classified as those which bring frustration and those which produce fulfillment, and since there is a gradual elaboration in the loter novels of the themes in City Block and the addition of new attitudes which lead to an ever-widening perspoctive on the part of the author, it is necessary to make an analysis of the marriages in all four of these 
books.

\section{Anelysis of the Marriages}

That "all happy families resemble one another, every unhappy family is unhappy aftor its own fashion" 1 is conclusively proven by the fictional marriages of Waldo Frenk. The few successul ones, as we shall see, conform more or less to one pattern, but each unhappy marriage is a failure because of certain conditions and circumstances which ore peculiarly its own. Because of this fact, I shall analyze the one general pottern for the marriages that bring fulfillment and that ve may call happy ones. The marriages that end in frustration and unhapiness will have to be studied seperately in order to present clearly all the factors which Waldo Frenk sees as contributing frustration. The analysis will present the sevoral types of marriage and the treatment of two phases - - the physical and the psychologicsl.

\section{Marriages of Fulfillment}

Three marriages of fulfillment which may be found in city Block are: Anna and Micheol, Suchy, Lotte and Isidor Rabinotich, and Mr. and Mrs. Bengti; one the The Death and Birth of David Markand: Marita and Juan Fierro;

1. Tolstoi, Count Lyoff 
one in Summer Nover Ends: Dora and Oskar Petersen.

These five unions which bring contentment and happiness to the husband and wife are, first of all, those made by the lower middle cless - - the struggling rorking people who have very littlo education and no financial security. The women, without exception, are the peasant types - - ignorant, uncultured, but loving and good. The men are of the same class - - hardworking, content, and unquestioning. There is a complete lack of physicel attractiveness, both in the man and in the woman. Although they have neither the mental possibilities nor the worldly comforts of an average family, they are content with each other and their children, asking nothing better of life than what they have. How little physical ettractiveness without other quolities means in a morrige seems to be emphasized in all these, especially that of the Benatis. Her son, looking a.t $\mathrm{Mr} s$. Benati, thinks:

Mama seemed ugly because she had so thick a skin: olive-green, leathery, always a little oily. And her black hair was a mane I have seen her break a comb in it. But it was good to look at mother. Her grey eyes were deep. Her hands were sweetly cool! Her voice was low, it throbbed so very quiet. No wonder father who was young and had a voice like a cornet loved mother who was fertile with mellowness, who was kind and deep and quiet like a horvest field . . ugly mam whose smile made me sad, so full it was of beauty. 1

I. Frank, Faldo, $\frac{\text { city }}{1922)} \overline{\frac{B l o c k}{\text { p. } 306}}$. ( Darien, Conn: Waldo Frank 
The element of understanding, seasoned with compession, must be present if the merrigge is to be one of fulfillment; it may or may not be a part of deep, abiding love, and the author portrays it both ways. The marriage of Lotte and Isidor kabinowich is a good example. Lotte was filled With compasion and understanding for her husband and for the whole world. She gave to him and to their child the wealth of a great coul, pouring out upon them the mercy and kindness that heal the world. Then, too, "there was a light shining within the lives of Lotte and Isidor Rabinowich", 1 and that light wes the mutual adoration which they heeped upon their son. As the mother looks at him and then at her husband, she breaks into this chant:

- 0 you who work beside me and who are weak, Whose weakness I share end shell shere alweys, Behold re have brought forth strength! - Our peth is darkness we must walk it our bed is darkness there ve must lie. Shadow is the world. Shadow is the world. Behold we have brought forth light!

- Wy flesh is yours whom I could never love, Behold it hes brought forth Love! 2

These husbencis are unprepossessing, slow, ativerd men who will never rise above a day-laborer. Neither big business nor power will ever come between them and their wives, for their ambitions and possibilities do not point the way. The fact that the women are too busy with work and home and children to harbor discontent, to brood over 
their condition, or to find fault with their husbands, goes far toward accounting for the success of the marriages. Something of this is given in the marrigg of Dora and Oskar Petersen particularly. Dora morked herd all day in a delicatessen and came home to prepare dinner for her family. Oskar worked sometimes, but more often he did not. He stormed and reved end muttered sometimes obout being the heed of the house, but Dora went placidly on, managing always. This scene is typical:

The fifty year old father, the fifteen year old son, were both subjects under the benevolent reign of two women: a. matriarchal state more typical than Americans like to admit. They never had a word to say to one another, having as to their body needs no common grievance and cultural interests as mutually alien as those of the average

Ecuadoran and Alaskan. This, too, is typical... It was always a jolly good morning, something. of 8 feast day, when Dora baked. Dora sat with her two men, her knees wide-spreading the taut grey skirt and her bare elbows on the toble. In some form not physical, she loomed and bulked, although in foct both men were as tell as she.

It was hot in the shaded room, the beer Was good (she had a bottle also for herself), and the men were good. Not a bit of them would she have changed! - . There were almoys her men who needed to be taken cere of. And she knew her men: knew the faintest wrinkle on their souls and she knew their skins.

Since he was her man, Oskar was a good men to Dora; even though prone to lunacy, like a.1 men. 1

1. Frank, Watdo, City Block, pp. 232-3. 
Marriages of Frustration

City Block

The marriages of frustration as presented in the short stories in city Block need to be considered because the reason for their failure in each case forms one of the basic causes for the frustration in the morrige relationships which ere presented in a more complex and complete analysis in The Death and Birth of David Markand and The Bridegroom Cometh.

Sophie's merriage to Victor Broddan in wurder is one of complete frustration and great loneliness for her. Her husband permits his ambitions for a future in politios to shut out completely Sophie and her desires. Because her first baby is born dead and the doctor refuses assurance that she can have another one successfully, Victor decides that he cannot jeopardize his future by going in debt to try again. He becomes completely absorbed in his career, changing into the cold business men who never soes that his wife is starving for love ond companionship. He robs this quiet, dignified woman of the normal, full life rhich she is so copable of receiving unto herself.

Her husband was full with his ambitious life. She ceme to know the herd will of her husband. . She did not understand, but she felt that it was cruel. She received his cruelty, the seed of fear thet lives in cruelty like a seed in a hard shell she received also. She was a woman, she was a receiver of seed. She was a woman who needed another seed than the herd will of her husband.

He lay beside her at night. He was very 
near and aloof: a dull knife that her love threw herself upon, and that would not cut her. She was all whole: Like o knot she lay writhed beneath her man who would not cut her and loose her. She went forth from him into the hammering world: it also would not loose her. 1

Bsther Lanich is Under the Dome: Aleph is miserable and unheppy, dwelling in complete chaos because she has no love in her heart for anyone. One of Waldo Frank's recurring themes is manifested here: that one must love if one is to live. Esther despises her husband, hates her baby, and has nothing but scorn for all humanity. She is efreid of life and will not let her pent-up soul pour warmth upon her family.

Dora Carber and her husband Godfrey, portrayed in Candles, live the marriage wherein each is solely dependent upon the other and both are completely shut aray from the rest of the world. They, lost in each other, do not edmit people into their lives. When her baby is born dead, Godfrey is glad, because he has vanted nothing to come between him and his wife. Then she realizes that he does not try to understand her suffering over the loss of the child and that he hurts her cruelly by deliberately refusing to become one with her in this tragedy, all life seems to go out of her, and he, too, becomes hopelessly bevildered and lost. Theirs is a marrigge of complete frustration because they have lived for themselves alone,

I. Frank, Waldo, op.cit., p. 37 . 
never permitting the love for fellow-humans to widen their hearts and broaden their souls.

In the story, Ecclesia Sanctae Teresae, Mrs. Lipper reveals to the priest to whom she has come for advice that her marriage to clarence is a foilure because she has never been able to give herself fully end wholly to him. She loves him ond has never denied him his physical rights, but even in this sexurl fulfillment she has not been able to become fully his. The priest is drawn irresistibly to her on this christmas Eve, and they come together - searching, seeking. After their sexusl intercourse, which both seem powerless to prevent, "her eyes were different eyes. They were the eyes of a woman wise and sure of herself." 'I have something now to give at last to my husband! ' she says." 1

The Death and Birth of David Markand

Many of the themes which Waldo Frank presents so simply in these short stories are treated with sociological and psychological significance in the marrige of Dovid and Helen, anolyzed thoroughly in The Death and Birth of David Markand. After eleven years of married life, during which time they have two children, they find themselves unhapy, both suffering from a sense of frustration. They

1. Frank, Waldo, City Block, pp. 298-9. 
feel that their marrigge means little aport from the physical aspects, and Helen has turned to the catholic church in an effort to find some meaning in life. There are three phases to Helen's quest for the absolute: faith in materialism; faith in materialistic man who is without faith; faith in Catholic anti-materialism.

Always, ever since we married, in my search for a truth to live by, I have been absent from you. Why? Because you would not seek with me. You made me do it all alone. But now I have found the truth, its first gift is to bring me back to you, since all glong I left you only because I needed truth in order to be really close, really yours.

Have you ever been concerned in my need to understand? Think back, David! When we married, I gave up my work at the Institute under conrad Westerling. You never really knew what that meant. - What it did to me. It was giving up a life. Conrad was a magnificient materialist, sure that truth could be measured, and only whot could be measured was true. I believed this also. When I loved you, that faith died. For Conrad loved me, more than you, and yet his scientific faith meant less to me than you who had no faith at all. I adored something in you a million million times more - it was not to be messured, it wos not passion, David, not yet. Yet it was strong and true. For years, to be your woman was my religion and my life. I lived vrolly in you. . . that wes my truth. Until I realized it could not last, becsuse you yourself did not accept it. How could it be truth for me when you did not believe this truth, yourself? You vere asleep, living in sleep, and seemed to need no truth. Living less like a man than like a plent. Just growing where you happened to have taken root. I could not stifie my mind any more.......

I begen my search again for the truth I must live by! That search, I made alone. Always alone. While you went on sleeping. . . What I want you to see, Dave, is that you left me alone in that crisis. You never saw or felt, no.. not when you were closest 
in my orms. But now, I have found what I

sought. . And now, you must be with me.

A women can seek alone, if she must, without

her beloved. But when she has found the truth,

thet is life: and I must live it with you. I

Dovid's point of view is different. He sums up the

rensons for their unhappiness thus:

I see it now. I need to be clear of

you. . It's your sureness, everything,

strong I feel strong in you, perhaps, that

I must run avay from.. Uüntil I am free

of something in me thet is dying; my whole

world in me, Helen, that is your world, and

must die. It will not die and set me free,

until I find a new world to toke its plece. 2

A clear insight into their years together may be seen

from their thoughts end words on the night when Helen

reveals to Devid that she has definitely joined the church.

Both of them had been restless and unlike themselves for

some time. He vas es one waking from a deep sleep end

feels life unreal:

Helen sensed her husband's state, and

thought she understood. Longer then he, she

has been avare of a trouble, like a rising tide

in him. - $\mathrm{He}$ is not made for the animal exist-

ence we have led, and at last, at lest! comes

the beginning of the end: restlessness, vague

unhappiness, then seeking, and then finding:

She had been through it all o little esrlier

than he, $e s$ wes right in a woman who unconsciously

assumed her greater meturity and strength. She

has found, after what seerch! the hoven. Now

on the anguished and glorious threshold, she vill

veit to toke her husband's hand that they may

go in together. Helen feels the man's physical

desire storming against her in the quiet room,

and it frightens her and celms her. For two

weeks, such crucial deys! she hes deftly

1. The Death and Birth of Dovid Herkand, pp. 412-3.

2. $\overline{\mathrm{Ib} i \mathrm{~d}} \cdot$, $\mathrm{p} \cdot 344$. 
Qvoided his ceresses, and in his strange way of long unconsciousness end sudden action, he seemed unaware of the unusarl deprivetion until this hour. But tonight she must speak to him first! She dere not put it off, an Authority higher than her comfort spoke to her this morning. How will what she has to say blend with this hunger of her man, kindling her omn, to let their bodies, in silence, know eqch other? -- There will be no embrece tonight! Why not weit rather with my words? After the caress and the sweet release, when he knows afresh that I love him, let me speak! No, it would be an outrage to him; love connot rise on cowardice. Wuch as she rejoices in his desire, knowing the full food her body is to him and the mortal life that his has been to her... knows the woman born at last and at last able to be known. 1

David, waiting for her to come to him, looked et her books.

Does one know his wife, he pondered, when her mind is full of unshered vorids like these? Well, she does not shere my business. Whet the hell is business, a shellow bag of tricks! But the books one silently lives rith? Instinctively, Morkend knew they did not metter. Their many voices negeting one znother were remote from the heart of living. He thought of his afternoon with Lois, of his need not for Helen. - You live with a woman, eat and sleep with her, beget her children; you live within her, year efter yeer consuming her beauty like food. But do you know her? 2

Both of them, then heve a feeling of frustretion;

they heve missed something soul-satisfying in their reletionship. Helen seeks to find her pesce in the church, end David searches for fulfillment. Yet, both speak of the deep love for the other; as far os they themselves are able to tell, there is nothing but love for each other in their hearts. They have been liberal-minded with each other. 
David relates this phase of their lives together:

He had been almost unexceptionally true to Felen through no virtue; she held him. A single handfull of times in eleven yeors of marriage, he had casually dropped into bed with some women, 2 lways when Helen was away or unavailable. He elveys told her and she, convinced of his love, seemed not to care. (At the time of her operetion, she said to him: "Dave, I cen see that this is hard for you. Cant's you find some pretty woman, just for $e$ while?") I

Her news that she had become a Catholic after all these years stunned him:

This wos serious, this was no "intellectual conviction" found in her books. If she had told him she had loin with a man, as he with Lois, it would hove hurt him more, and been less serious; he would have felt her less far ond less lost. This was an infidelity, although to know it was amazement, more destructive than a man's mouth on her breasts which he loved, yes, than a man's passion within her flesh that was his home and his altar. - She ras whole, and he for the first time outside her. He felt himself crumbling as a leaf dropped from a tree and lying upon

On the other hand, Helen is convinced that everything will soon be all right between them, and, relying on that feeling and on her faith in her church, she is marvelously potient with him es he fights his battle olone. He is ultimately unable to enter into her security, and, aisposing of his business, he leaves home to wander in search of himself and the true life which he knows he will find. Helen does not despair, however, for she believes he

1. Frenk, Waldo, op.cit., p. 33 . 2. Ibid., pp. 40-1. 
will eventually come back to her end that their marriage will be an ideal one. Although she seems so sure of her heppiness and her peace now, she does not become a better mother or wife. She does not mean any more to society than she had ever meant. She lives for herself and her femily. Waldo Fronk lets us soe clearly this fact when he gives us the picture of Helen preying in the church. A very poor woman is kneeling beside her. The son of this pitiful creature hed been hurt in the foot and needs an X-ray made. She was praying for money to save her boy from being a cripple.

The tro women rose at the same time, and Helen smiled at the wan, sweet fece in the gray shawl. "Instead of her smile, "thought the moman," I wish she'd give me the money for that $x-r a y \cdot "$ But Helen, despite her closeness to all men and women, did not hear her.l

How utterly she failed to satisfy David may be seen in The Bridegroom Cometh. He had returned to her from his wanderings, and again they had tried to live together.

(Markand was thinking of the evil in the vorld.) - You have to know evil in yourself to know evil; you have to know yourself. And the dogmas of most socialists bar the possibility of self-knowledge. I've gotten pretty wise; but what is self-knowledge that doesn't act? Another name for evil? He thought of his wife, Helen: she and her catholics believed in evil; but not in action against it. They turned to a magic called the sacraments to get rid of the evil. - And the magic generetes another sort of evil. I don't believe in magic; not knowing where to turn, I turn impotently wise, emptily rise? 
A Catholic churoh behind him and above him shouldered the city. He thought of his wife who was wholly in the hands of the church: the long attempt at peace between them upon some mild collaboration or at least tolerance, was failing. War was ahead with his beloved Helen. winter.. And the night obove the cold, monumental church was soft.l

Helen's peace, therefore, was for herself alone - a sort of blind satisfaction that embraced no obligations to her fellow men or to society in general. When Markand meets liry Donald Taess and knows a groat love for her, he has found a person - a well-integrated human being who has preferred any sort of deprivation to a life of shams and shallow pretenses. She was the one who ends his loneliness and his search - she was his answer to his years of questioning.

Helen and David had lived for themselves, both blind to the world, both sleeping. From the sense of their frustretion, Helen accepted the church for her substitute, and Devid, repelled by whet he knew to be a mere substitute, went forth to seek life as it should be lived.

The inability of modern men to satisfy their women is found in the marrigges of Lois Pollard and Theodora Lenck.

Lois is restless and lonely. David "saw that under the soft features, her face was of hard structure. Here Wras simple strength, given to Lois by her race. But the 
beffled hunger in her eyes made the strength remote like thet of a tigress in a coge." 1

David tried to place Lois on the day he has his sexual reletions with her. "He could not see her clear, she was neither the woman of today nor the girl of the past. All he could feel in her was a void." 2 Narried to charley Pollerd for years, Lois had a sense of frustration that she tries to allay by furnishing herself an apartment, a hide-out, and there she takes David. She says to him:

"Cherley's all right and I suppose I love him. Anyway it's been easy to be true to him, if that means something. But he's e bore, and he could get elong without me, and so could Junior since they took him from my breast when he was three months old. I've not done a real thino for him since, for there's elways been a nurse or a cook or a doctor or a teacher that could do whatever it was lots better. What I could do best was pay for them. Yet I do love him. Hore feelings that do nothing." something?"

"Whet would a feeling be, that does

"A thrill. When a feeling charges you, even if it's a pain, it's a thrill. And when a proper woman has one or sees one coming, she's got to stop it! It was a thrill giving birth to Junior: that was a feeling that did something. And if women were bonest they'd tell you (lots of them at any rate), they's lovo to have a baby every year." 3

Theodora Lenck hed feiled to find fulfillment with her husband, on executive of the meat packing industry in Chicago.

Lenck was a failure of hers, and she knew it. I. Frank, Woldo, op.cit., p.65. 2. Ibid., p. 17 .

3. Ibid., pp. 28-29. 
Maybe, she thought, the big job and the war will give him more confidence. She smiled, and Leighton Lenck grew pale with promised ecstacy. If he could once possess her, he was cured of his feebleness. She had done what she could, eqgerly giving her body in return for what he gave her. But her eagerness was not the love he needed. It was will... good will, perhaps... and will could not enter him to give him strength, it could only touch him to destroy him." 1 .

She had many lovers, seeking surcease from frustration, but they all failed to satisfy her. Instead of going to England with her husband, she went away with Markand. After their affeir is over, she goes to Hollywood, but that life is empty, too, end she kills herself.

\section{Christine and Stan Poldiewicz}

Christine and Stan love each other derotedly, and there is the great bond of understending uniting them. Yet their marriage ends in frustration and death because they have shut out the entire world and have broken all contact with their friends, families, and loved ones. They try to be everything to each other, and they are not able to make a satisfactory adjustment with society in general.

\section{Hester and Phil Dwelling}

Hester loves power and money, and she does not hesitate to place these gods of hers above love and sympathy. She pushes unambitious Phil to the front in every way possible, I. Frank, Waldo, op.cit., p. 358 . 
deliberately killing all emotion and affection which might have existed between them. She says:

"In the days when I still dreamed of love what did I care for politics or pover or women's rights? It's only as I saw the hollowness of the thing that I grew sensible. Lovemaking and seriousness don't go together. Either a woman's a. fool, wanting a man to kiss her body, or she is sensible and finds a work in the world." 1

\section{The Bridegroom Cometh}

The three marriages of the women of secondary importance in The Bridegroom Cometh form a complete background for a full presentation of that of the main character, Mary Donald Taess. Although all the marrigges end in frustration, it is in this novel that the author definitely tells us how a marriage of complete fulfillment may be had.

With the three themes for a background -- liertha as an example of the roman who gives up all contact with the world and with other people in order to live for her husband alone, only to find that this ends in frustration and death; Doris Granes as the highly intellectual woman who finds modern man too shallow to satisfy her; and Lida Sharon as the one who gives her life willingly in order to serve humanity and the cause of labor with which she is affiliated, never thinking of herself - - one finds the marriage of Mary and its outcome complete presentation of the problems

I. Frank, Waldo, op.cit., p. 283 . 
confronting modern woman in marrige.

Mary is the mystical seeker who yearns for the good elements which she finds in the other three merrieges and Tho suffers absolute frustration in her life with villem Tress because the evils found in other marrigges permeate her orn. She is ever seeking, both within herself end in others, for those qualities mich will produce e perfect Whole, and she will not accept less than this. we shall, therefore, make an analysis of the other three merrisges before considering that of wary.

\section{Martha and Sid Farvard}

In order to understand the merriage of Wartha and sid Harterd, one hes to study briefly their relations before this time. Wartha hod met sid when she was but a child, and she never forgot him. It was as if she were moving steadily toward him in everything she did. When she had secured 2 job in the same mill where he rorked, she $s$ w him again, and it wes not long before she was going to his home for seruel indulgences.

- . Horthe does not know where she is going. Whet matter? It is right! Everything is in its plece; everthing thet heppened, or could heppen; beceuse everything is rithin her need of sid: and that is everything, and is right. loving across town through the April gloaming, liarthe was not going anywere and was not moving; since everything lives within her heart and her heart is steadfast. 
By law of the same fixed possession, she foresees and foresenses nothing. She has no image of the man she is to be with, of the plece where she will find him, nor of what he will do, what she will feol of his hands and mouth. No feer she has and no joy;

almost no interest. All these are deviant emotions of the soul or flesh when sundered from one enother." 1

In giving herself completely to him, she was doing that which she must.

She ley while he rorked, searching, strong, quiet. This was not pleasure, this was not joy: this was pein; but hed it been so great as to burst her flesh, it was nothing: it was the sorrch of Iife in life
for life.

Then:

A shadow stirred in Marthe... something to fear. It was fear! Death... Near her! She became herself, feeling death there: herself seperete dreadfully from the naked man beside her, to whom she wes joined forever. 3

Sid was the perfect gangster type - the nihilist;

hard as nails; eager to make money the easy way and fearing nothing but poverty. He had used many girls before Marthe, but she held him. He once said:

". Christ, I been with you months already! I tried a couple of others, I got to admit they don't taste so good. I don't like it. And it's all your doin'. Why, you fat little bitch, until you come elong, it was never like that. No sooner'd I have girl, than I was ready for the next."

"You're hurting me!"

1. Frank, Waldo, The Bridegroom Cometh, p. 16.

2. Ibid., p. 161 .

3. Ibid., pp. 161-2. 
"Hurtin" you? If you don't like it, get up and get out. Why don't you? You're a Goddamn cute bitch; think you got me?... Just wait. I ain't anchorin' to no woman. I want more.. " "n you ever heard of." His hands were still hard on her breasts; but his eyes were childish.

"Sure, you're pretty swell. Compared to

the other janes in Merling you got me any time and every time." His hands, convulsed, hurt her. "Whet does that prove? How do I know what New York's got? Some day moybe, you'll look es cheap to me as a French Canuck woman looks to me now, seein' you."

- - And liartha closed her eyes, shutting in to herself the sweet boyishness, as he kissed her... the death. 1

They met in New York some months after Marthe had

followed him there. The joy was mutual:

And it was easy, this violence of

birth: this sudden revelation through his presence that life is in her, now she lives: Who but an instant before had not been living - - the sudden birth, yet easy as to stend letting the air ond his voice into her lungs. "Wartha," he whispered huskily. "God!

Come let's get out o' this."

She saw, first, an impossible thing: sid seemed smaller - Something has shrunken him; then she saw irrelevant things: the smart gray hat, the blue serge under the gray top coat. She felt in the fece more drawn and in the eyes more feverish, the little hungry life that was the man, and she its hunger! Her heart came alive for him in pity of the hunger, and in fear of the folly and the danger she illogically felt in his prosperous clothes. She said nothing: his hand bit $\dot{x i t h}$ the gld brutality into her flesh, and she followed.

Sid took her to a hotel, locked her in, after having provided well for her comfort, and told her to remain there until he came to get her for their marriage. She did not

I. Ibid., pp. 188-9.

2. Frank, Woldo, op.cit., pp. 190-1. 
try to find Mary or to see her, but one day they met, and Martha invited her to dinner. When Hary Asked pertinent questions about Wartha's lifé, she did not answer her, pretending not to hear.

Martha and Sid lived in a suite of rooms in an $\theta x-$ pensive hotel, and it was evident that they had plenty of money to spend. In fact, he became exasperated with Martha because she could not spend more for her own desires. He had no regular working hours.

Nirthe used the word often: "Sid, when will you be home?" "I was home all day." It was like when she bought things and had them sent to "Mrs. Sidney Harvard". Her love was real, so was Sid's: why was its world unreal? Seeing no one did queer things to you. You rere lonely, and yet you were afraid even to see Kary. Your husbend never brought a. friend to the house, you were never invited out with him, you wondered, but you knew it must be.

- Must be! Thet was the word for everything since his hond drew her from the subway station, from the crowds making a fuss about nothing. . they called it Peace. I

Sid went out usualiy about four in the afternoon, returning about midnight. "Then came the best hours. Often there was a hot excitment in his eves, a twitch of his mouth, and when he loved her, Hartha felt he was racing to his refuge, pessionate less for joy of her then for escape from some danger." 2

His being a bootlegger and working with a ring of

I. Frank, Waldo, op.cit., pp: $220-1$.

2. Ibid., pp. 223-4. 
criminals made them lead an unnatural life. When she asked sid why this or that must be, his inevitable answer always was "Must be." That became her world and she lived in it and accepted it.

One glimpses Martha's feelings in this passage:

Martha wanted Mary to come; she wanted wary to be here now with Sid; alone, she dreaded Hery's presence. She's gotten used to being alone. Words with bellboys, waiters, manicures, milliners, modistes, words with chance ladies in the lobby, were words of silence. And living with sid was also living in a silence. Being alone! the words with sid brought nothing close, the sweetest hours with sid were the most perfect absence. liary was presence. Now Nartha knew thet the gray Mariing kitchen, the school, Loomis Lake, the hotel at Sunlight, hed been real, because of Hary! She made things real! - I don't want her near me! Martho tried to think of Mary: - Maybe she's lonely, maybe the kid needs me? She could not make wary alive; her loneliness threatened, overwhelmed her in its own penic. For a moment it glanced through Martha how this life of absence with the man she loved emptied her, except of submission and cruelty! Must be! And the tringe went. . even if Niry is in trouble. 1

Wary knew that Martha was not completely happy, that something was wrong, even if she and sid did love exch other. "Mary sav hartha married to a man she loved and who loved her, and both (she knew not how) ageinst the world. Her heart overbrimed for Martha. . . with her man against the torld." 2

Iratha's world had closed in on her, crushing her heart, because she hed excluded everyone from her love, 
sympathy, and understanding but sid. Could she have the baby' she ranted so badly, hers might not have been such a tragic fate, but sid anorily demanded that she have an abortion as soon as he learned of her pregnancy. Mertha had wanted this baby, and when he had such a fit of rage at her even suggesting such a thing, she thought of killing herself. He dressed her, looking at her 211 the while with his black eyes. he kills me

Only his eyes were important; they were not speaking the kind words, they lived their orn life. - not caring for her life, not carine for his life. They were leading her now to deeth. She had always known it rould

Sid was angry, becouse something lived botween him and Martha's body. He was killing it, double-quick time, God damn it! but there it was! Martha's body hed been unfaithful, and Marthe couldn't help it, and that was just what made it bed. If a man touched Nartha's body, it would be easy: he would kill the man and lorthe. This intruder hod crept in where no life must be but his own flesh, and he could not kill Martha. He knew he could not kill her, it was not her doing. It, he will kill! but it hos lived in her as his own root; it throbs, it grows in her! Sid's anger, possessing him, did not speak to him. He did not know why he sat nervous in the car, why he hated liartha. yet longed for her and felt he must talk sweet: why he set coved like a licked boy. 2

Martha's heart and soul were hurt by the abortion, but she did not talk. Wonths later sid was killed. For days Nartha had woited for him to come, and then she knew 
that some rival mob had finished him. As she told Willem, "If he was alive in Hell, he'd speak to mo." 1

Martha seemed asleep, too stunned to talk or grieve or weep. Mary tried to break the terrible calm within Martha, but she could do nothing. It was as if she had died, ond in her eyes there was emptiness, "the void of an immense possession gone forever." 2

Martho existed for some months, but her life was over, and nothing Mary cquld do ever aroused the least animation in her. It was merely the ending of days when Martha. slipped into Loomis Lake one night, drowning herself. The death she hod felt in her relationship with sid had overtaken her.

Martha's love for Sid is an example of Mr. Frenk's belief that woman's hunger and man's hunger, sexually, often bring death. The Martha-pattern is similar to that of Christine and Stan Poldiewicz in The Death and Birth of Dorid Markand, in that the wife gives up friends, family, and world to be close to her husbsnd. The end is the same death.

\section{Doris and Peter Granes}

Doris Granes, Socialist, teacher, and writer, is herd, worldly, and unbelieving when the reader first meets her; but one senses thet she has great possibilities. She finds nothing in her married life with Peter to call forth the 
best that she is cepable of being. He is a newspaper writer, a cynic, and a shallow thinker.

The relationship of Doris and Peter is far from an ideal one. Even while Doris is teaching at Winant, one becomes arare of Poter's jealousy and his attitude towerd their union:

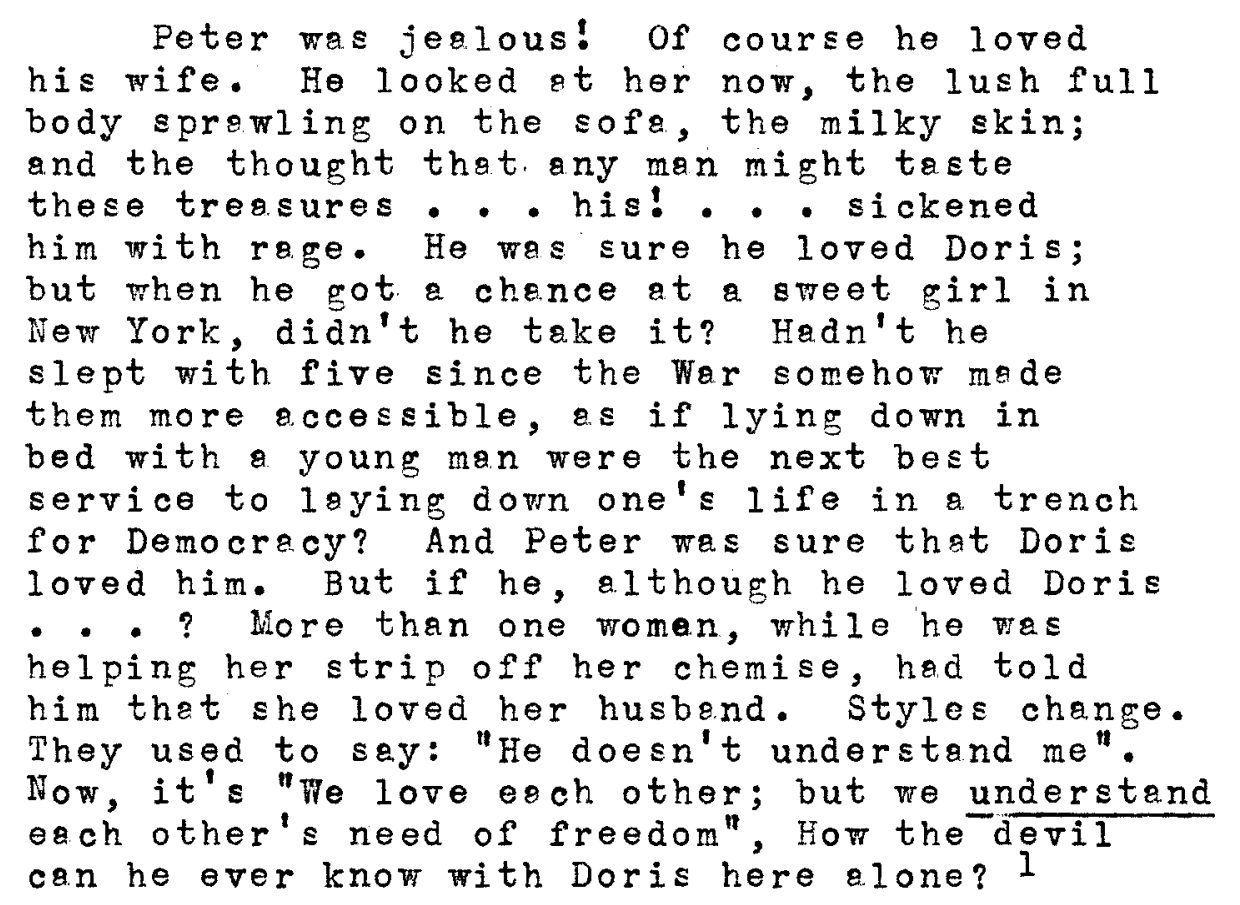

He was expecting of his wife that very fidelity that he was unwilling to give to her and that he had no scruples in destroying in someone else's wife. He desired a married Iife that calls for the double standard - an outmoded custom in our dey and ege.

Once Peter, finding Mary alone in the apartment, tries to make love to her, but she repulses him, asking, innocently, how he would feel if another man kissed Doris.

I. Frank, Waldo, op.cit., p. 169 . 
Immediately, he. is a flsme of jealousy, trying to force Wery to tell him if Doris has a lover. She shames him for the very thought and he is silent, glad she had given him beck his security in his tife.

Niary knew then that Poter was at war. . thet he had no peace within himself. She, however, hed been worried ebout Doris ever since she came to New York, for she had known immediately that the teacher whom she adored was not happy. When she entered the apartment for the first time, she kner that "Doris was never there", l spiritually, wholly. She worked until noon on the book she wes writing, but it was not at home. Peter never spent a quiet evening at home, in fact hary scarcely saw him except when there wos company or a perty. Mary asked herself questions about Doris:

Is Doris happy? at peace? . . were questions as impossible to the vague enotion wherein she held Doris, as years before they would have been about Jesus. That emotion did not break; Mary could not judge, nor doubt Doris was wise and true. But within the acceptance, here in her home, were facts that must be seen: Doris flaming from her room, torn with anger, "I can't work!"; Doris in ugly temper against Mary, her husband, the world. This was not all Doris: she could be charming, motherly, tender. But Doris olso was at war. - . While the stregt shouted Peace, Peace wos undiscovered!

One day, coming home early, liary surprised Doris with her lover, Edgar Dret, a friend of Peter's. She knew,as soon as she saw them sitting guiltily on the sofa that he

1. Frank, Waldo, op.cit., p. 196.

2. Ibid., pp. $199-200$. 
was her lover.

Mary saw him, the clever hands, the smooth small head, the well-fed body: No God smote him: Doris, too, got up. It was a pain, the seeing them together, as of her arm bent back till the flesh tore.

The door opened and shut, they were together in the hall. The door opened again, Doris was there.

Wary could not 1 ift her eyes, she was all

shome. Doris stood for s long moment over Mary rigid in her chair, her head down, clutching the seat as if it whirled in an abyss. She sat heavily on the sofa.

"WelI?" she said.

Mary felt the woman's will, the loved

one's, prod her eyes upward. She lifted her head and looked ot Doris. She wanted to run oway, she ranted to cry, she wanted to fling hereelf on Doris, kiss her and say: Forgive me!

"Well," Doris repeated, "I'Il say it for you. You know it now.my dear. He's my lover." 1

Summing up her excuses for her guilt, Doris reached

the actual reasons for the bad situetion.

". I'm glad about this. I'm going to talk to you, Mary. To begin with Peter: he mustn't know. If Peter knew, it would simply smash him. He's o child, he clings to me like a mother. His smartness earns him a good living; just the same, he's brittle as a biscuit. All the strength he's got is his security in me: thinking I love him glone."

"All right, that's Peter. That about me?" Doris Solberg Granes got up; her hands clutched her throat, then fell to her haunches and she paced the floor, a peasant woman. liary watched her.

"There's only helf-men in this twodimensioned town. I'm a woman who needs a man. God, I do: I'll tell you, two half men don't make one man, despite all the mathemetics."

1. Frank, Waldo, op.cit., p. 201. 
Again she sat on the couch. "Don't you dare blame me, you damn little Puritan. Wait till you're a woman. . . . You're not born yet, and that's why you sit there and judge. Sure, two half men don't equal a man. Not twenty half men equal a man (and maybe, I've had twenty). And trying to do a novel, that don't equal a man, either. But when you're a woman you take what you can get. Even the half men. You hold on to it. You don't say: the True, the wonderful, or nothing. Not by "a long shot. Hot when you're hungry, . . . . " 1

Mary, out of her deep hurt, humiliation, and disillusionment, struck Doris full in the face. She began to see her more clearly, and knew that Doris's nind was "hurting her, hurting the secret place where one must live. A womb in her was being blighted. By her mind? Hary remembered what the biology professor had explained about the radium lighting the live tissues of our bodies. ilary was sorry for Doris: she deserved better than the Peters and the Drews". 2

Fear, too, playod its pert in the failure of this marriage. Doris admitted it one day in conversation with Peter.

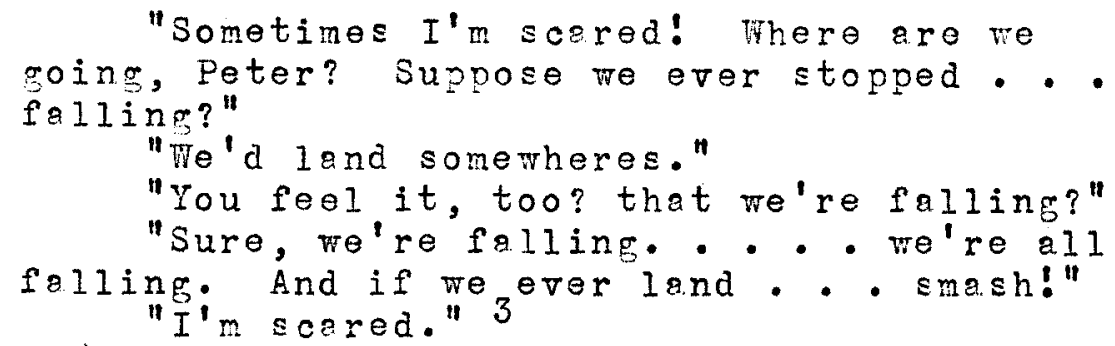

To Mary's first party in her new home sometime later, Feter comes exceedingly drunk. The smash-up for him has 
arrived.

$$
\text { "I'm celebratin' tonight, Wery. Just }
$$

dishcovered somep'n and I'm celebratin'. Doris sot a lover. Doris and Drew... just found out. . . ." 1

And yet these two go on living together, even though they make each other miserable and unhappy. Perhaps Dolg is right when he says of them a11:

.. So fer are you gone in your dissolution, that you love your chaos, you who spread chaos (ah! England), you make a god and a philosophy of your choos.

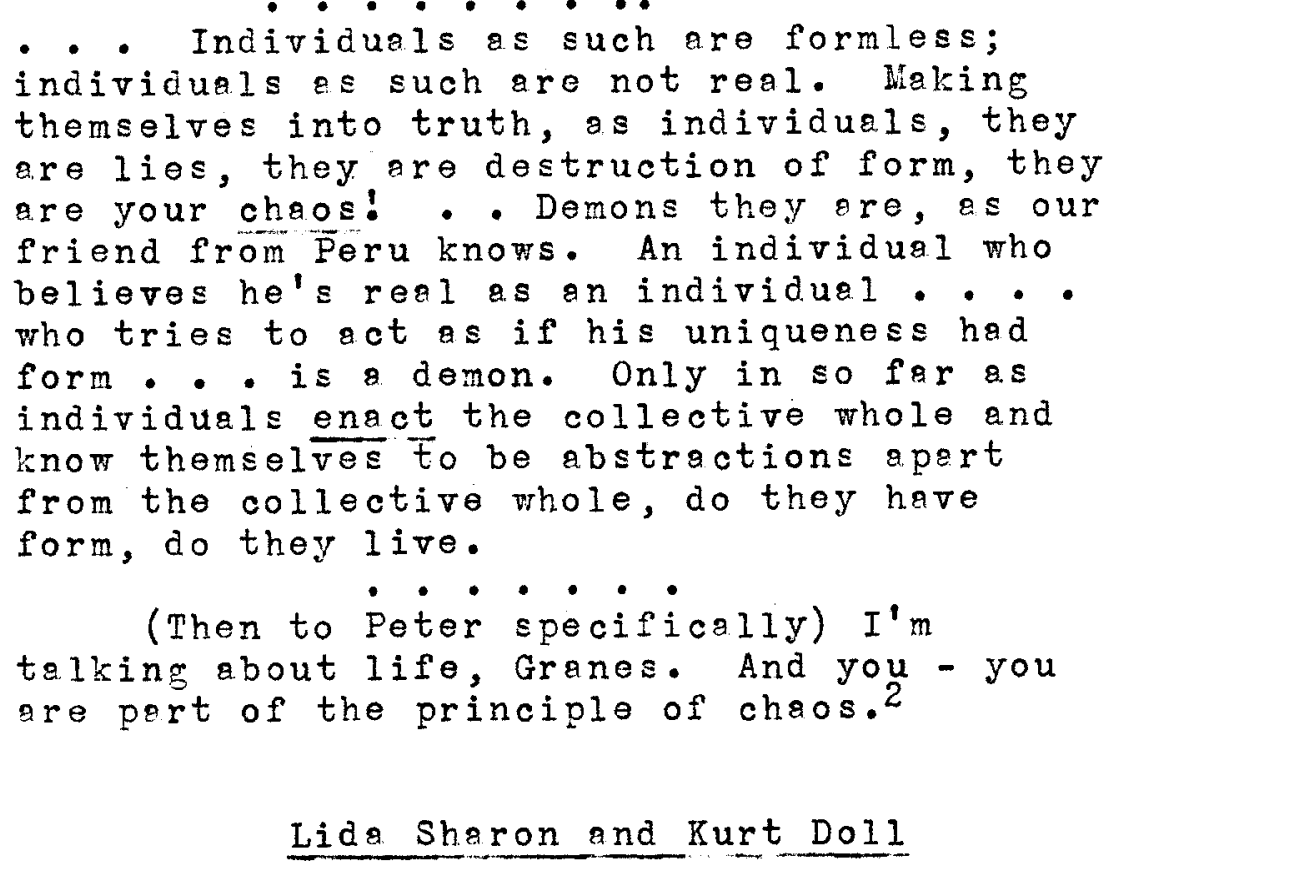

Lida and Kurt married because the officials of the workers' movement wanted them to be married and go to Howton to organize the porkers. He was twenty, ten years younger than Lida. He wrote party publications and poetry about

I. Bridegroom Cometh, p. 355 .

2. Ibid., pp. 398-9. 
lebor and the orgenization. Lide had rorked in the lovement for yeers, and the officiels considered her good because she olweys obeyed orders vithout questionine their rightness. She was a friend of liary Doneld's, and the two hed lived together for e long time. Lide and Kurt hed been lovers for some time.

Mary in bed lingered in the closeness of these tro. She knew the sporadic lovers of Lida's past: casual, unfortunate comredes who needed consolstion or just a women, and Lide res sefe. Why not? She knew how these men, toking for their verkness, giving only of their weakness, had cest a spell of sleep on Lida's body that accepted its om joylessness, its own worthlessness. But rurt and Lida rere close and her body lived! Lide vas whole in his devotion and wonderfully strong; he, the sprite-child with the sperk mind, wes esrthed in her! and he enriched as a young tree its soil. I But Lery felt that they didn't love life enourh, that they occepted death too easily. When she knew they were willing to be sacrifices for the labor movement in Howton, because tht was where John Byrne and Jane Priest had been killed when they went there to organize the people, she triec every way to keep them from going. The party felt that the reason Jane Priest hod been murdered was because she was living with John Byrne unmorried, and so they had ordered the merriage of Kurt end Lide. As one of the men tolỏ Hery:

\footnotetext{
"Well, you see, in case arything does heppen to 'en it'll look a lot better in the bourgeois press, they'll play it up a lot more if they were a respectable married couple." 2
} 
Mary appeals to Lide to refuse to go through with it, but Iida's ever-recurring answer is that she must obey orders and that she must go because the Party wants it. Lida says to Mary:

"Mary, you're a bad soldier."

"You think I'm afraid to die?"

"No, Hary. Thet's the hardest and bravest

of a.1. To go ahead when you don't see."

"I don't want to see, I want to feel."

"We have to be ready to give up feeling." I

Thet was Lida and her marriage - "To the fulfillment in Howton, to the flower of sleep that is death." 2

\section{Mary and Willem}

Mary had suffered greetly because of the foilure of Doris's marriage; she suffered infinitely more because she sensed death itself in Marthe's marriage; her longing for children and her love for them, together with her sensitive, tender feelings which filled her body, made her suffer; the fact that Martha had submitted to an abortion was almost unbearable. She was all feelings, and she was ever searching for the peace and ultimate satisfaction which she knew she would find somewhere. Willem Taess, the wealthy Dutch Jew, loved her and wanted her to marry him.

Thet Mary was olways unutterably tired and weary and that Willem was unfailingly kind to her and suggested restful, quiet recreations; that she longed for peace which she had never found and that he and his mother's house

I. Frank, Waldo, op.cit., p. 615 . 2. Ibid., p. 617 . 
seomed to possess; that her body lacked and hungered and she believed Willem could satisfy her; that her contact with children and Martha's tragic abortion hurt her; all these influenced Mary in her decision to marry Willem. None of them, however, would have caused her to make up her mind, had she not seen one evoning thot Willem really needed her bodly. When she made him admit it, "all his need entered her body". 1

\footnotetext{
"You've always felt I want to take care of you, Mary. . It's true. I want you to need me. It is I who need you." She lifted his face from her lap. She felt strong for the first time, knowing she was conquered.
}

They agreed to get merried at christmos, and he proposed thet she continue her studies at the university after their honeymoon. He was thoughtful of her and most generous, loving her with his whole heart.

Their wedding night which was spent in the Pullman of a fact moving train, revealed to Mary one weakness of her husband. Willem could not break through his fear sufficiently to possess Mary. She knew he was frightened when he did eventually come to bed, and she finally held him close until he fell esleep.

"She awoke in the gray damn, the night of violent motion and violent aloneness within her. . ." 3 When they orrived at the hotel, the noxt morning, and were alone,

I. Bridegroom Cometh, p. 284.

2. Ibid.,

3. $\overline{\mathrm{Ib} i \mathrm{~d}}$, p. 288 . 
She ronted him to make love, she ranted. him to tear off the deinty white candlevick from the bed; it wes rarm in this room, the sun glomed the curtains, and she wanted to lie with Willem and be open to him. Willem looked toward the bed and then he sat in 2 cheir. It wos morning, they could heor guests chatter down the hallway. Wary knew her husband could not dere make love with the world a make and impinging. Doubtless there mas a proper time for making love, not a night on a train, not a morning. - Hary looked at Willem, she sam the hands that had caressed her breasts and his soft mouth. . . She saw him. - This is my husband. The sensitive long foce in which solitude dwelt: - This is my husband; the heavy eyes: - This is my husband, and the mouth too frail. 1

That night she knew they must be one:

in that oneness she must know at last why thare is life. He sat, murmuring her name, his eyes

upon her, his body not yet moring. - I must be the strong one? only at the beginning. Only to free his strength. 2

She wos satisfied that all would be well ater their marriage was consummated. She was happy.

The ecstacy of her will daring at last to know itself alchemied ell thet happened.

The ecstacy of her women will was greet and sufficed, the ecstecy of knowing: - I am 2 romen now, and this is my man! She loved when he slept, oradually falling from her as - child from its motrer. 3

The nest morning, Wary a woke before Willem. She looked at him. "Mary sam Willem without his eyes, the face unlighted. For an instant liary knew this was not the faco to see the rorld vith; the thought, unbearable, glanced off into a shudder." 4

1. Bridegroom Cometh, pp.288-9.

2. Ibid.,

3. Ibid., $\quad$ p. 290.

4. Ibid., $\quad$ p. 290. 
Mornings were happy times. with them until the papers were brought, and then into his sense the world came and lived. He knew this, yet he could not refrain from having the papers. He knew that he must go deep to find Mary and give her oll of himself, which was all thet she demanded. She was not easy to arouse, as other women, and it must be he in his entirety if he were to keep her.

And Willem was divided.

Reading the news of the world, he sensed the barrier that living in the world made from the full knowing of Mery which alone could win her. The leakgge of energy and will into this alien world of news weakened him from liary and made him need her. I

Millem's absorption in his business and his utter dependence upon his wealth was forever driving them apart and holding them asunder, but he fas powerless to prevent it. He was not strong enough to break the hold his mother had on him, either, for he went to see her every night after work before he went to his and Mary's apartment for dinner. Ho was selfishly blind to 211 the misery and porerty and sorrow in the world, and he steadfastly refused to assume any responsibility for alleviating the distress of the downtrodden. He smothered Hery in luxury and resented any attempt of hers to reach out a helping hand to the unfortunate. It ras not as if he vented to be like this, for Willem was a good man in every sonse of the word; it was fear - fear thet his orn world of security would tumble;

I. Bridegroom Cometh, p. 291. 
fear that if he once began any sort of reform mork his own peace tould be gone.

Another problem of Mary's was the matter of children. There was in ilary a great understanding of children and a yearning for them. That was why her vork with the Parent's Aid had been so upsetting, tiring, and unsetisfactory to all concerned. Mary sympathized with the chilaren too much, and at night in her hotel room she could not sleep for their presence in her heart ond soul. "All she remembered was the faces of the chiloren". I They seemed to be crying for her to give them a body.

Her nights, sobered from the day's sweet cere of children, grew sad and herd. Soon the nelody of the children, bitter-sweet, made all she felt in life its accompanying

When she received the ossignment to take the children to the clinics and the perks, she dreeded the end of the day when she must be separated from them. Throughout this phase of her life, whot children meant to her and did to her soul is depicted poignentely end heortbreakingly. Yet, when she and Willem ere married, she refuses to heve children. She learned that her mother-in-lew expected her to have a baby as soon as possible, and she knew that Willem wanted one, but sometring inside her refused.

$$
\begin{aligned}
& - \text { I cen't love. I'm hard. That's why } \\
& \text { I can't give you c child, Wiliem, my husband. } \\
& \text { I'li use you. I vowed I wouldn't use you, }
\end{aligned}
$$

1. Bridegroom Cometh, p. 257 .

2. Ibid., p. 282 . 
between them, and lis ry decided to forget what she had seen and be happy with him. He soleced her with:

"Darling, don't think I don't understand. It's like you to have gone there. Yesterday, you sensed something wrong and terribly sad. You had to find out what it was. I admire you for it. But we're helpless, love. What con we do? The most we can do is spoil the little joy we heve. Oh darling, cen't we be happy just Fith each other?"l

There came to be in Mary the pert of her which cried to be allowed to live and then the other part which begged to be lulled to sleep. That struggle kept her tired and weary. Such thoughts went through her mind $\varepsilon s$ she worked in her apartment. She began to think! She knew something Wes wrong with the world. And then:

Am I wrong? Better reed the book before you jump at conclusions. I don't want to; I don't care. But something is the matter, I feel it in Willem. I have alvays felt it. Wherefore take unto you the whole armor of God that ye may be able to withstand in the evil day. forgot. I wanted to forget. I ranted.. The beds are aired enough. . Cold! Imegine this cold and no warm place to go in all the rorld! But you rould die. Imagine dying, and then wating in such a cold forever! oh, I want to be warm. . Tillem, dear, I want your bed to be warm. With you, warm. .

- I don't want to know. I don't vant to want. Dearest husband, I want to be warm.

- Shout it! Do you heer me, God? I don't want anything else! I don't want to believe in the noble words you once put in the mouths of Prophets. Hello, God, please listen. I WANT TO BE WARM. 
- Beware.

- Be warm and bewere. What have they

to do with each other?

I don't want to BEWARE, I want to be WARM. I

Her discontent with her life of ease ond her unwillingness to live a life of lovelessness grew 2 s her senses awoke. On the night when she had seen Hartha suffer so tragically because of Sid's death, Hary is returning home from Martha's hotel. She is walking through the tenement section near the river when she sees a wom standing in the dark in her yard sobbing. She did not ceese crying or try to hide it when she knew that Mary ras seeing her. Already upset by her sister's great grief, Mary analyzes herself:

Mary walking down the street lighted only by a women's sobs sees, as if dying, her whole life in a day. From the desolete,ecstatic dawn of the gray kitchen whose ceiling is the sky where Jesus waits, she sees the long freeing of her soul that was a rending of the flesh; the long quest upon the horizontal earth for another Heaven, for another Jesus. The long search, the never finding. The long day; at the end weariness, night and sleep. Night, not of this street but of her home and marriage, lighted by a roman's sobbing. Her love with Willem has been a conspiracy for sleeping. Her merriege a sleeping. - He will not want to wake.

As if asleop, Mary walks away from warthe. towerd home where she can go on sleeping. Ah, forever! With Willem's money and Willem's weakness and Willem's need to sleep upon her breast, she will be safe from waking.

But while hary sleeps, she says to hereelf:

- I sleep.

While she yearns aray from the wound torn in her sleep by watha, it is lighted by the

I. Bridegroom Cometh, p. 338 . 
woman, no less reol, who stands and sobs

before an iron gate. While she hurries

torrerd home, she knows: - This is sleep,

and she wos not born to sleep. The peace

she has known and loved.. . Jesus, Willem

- - she knows is a sleep before life.

She knows she was born to awake. 1

Willem knows he has failed with Hary. She seemed to by saying to him, "Live with me the true life; danger and foilure. Discard your mother." 2 And Willem seems to be unable to believe in medness even though it is true and even though it is life. He must have his comfortable place, his werm bed. Hary tells him she must go arry for a while, and she decides to go to clermont. Mary stays with Sarah and Luke carns and visits her grandmother and the pleces where her mother lived and loved as a child. She leerns that Sarah and Luke are unheppy.

Mary saw: Luke carns whose whole life lay beyond his wife's was fond of her, and Sarah who was grown into her husband, who could not live without her husband, hoted him. This steadest seeing made Mery strong, and strength was a new joy. Sarah distrusted what she felt in hary: it was outside her realm, and her husband liked it. 3

She sav "a boy imprisoned in his body." 4

Sarah told Mary that she would kill with an axe any woman whom she finds with Luke. Thet very day, Luke takes Mary to his hideout - a little cabin deep in the hills.

1. Bridegroom Cometh, p. 369.

2. Ibid., p. 383 .

3. Ibid., p. 411 .

4. Ibid., p. 411 . 
He tells liary he knew she was not married right. Then he confessed that he has needed to make love to her. Seeing his great need, she permits the sexusl intercourse, but none of the experience touches or arouses her at all.

The next day he takes her again to the cobin, but Mary refuses a second intimacy. He then tells her how lonely he is, that his soul is dead. Luke admits that he has needed to steal some of Mary's life because he lives with deadness. Mary, too, has always felt Luke's great hunger. Being loved by Sarah, he says, is like "bein' loved by one o' them sandstorms you read about in the Sahare Desert. - There ain't much difference between the love of certain folks and hate." 1

"You didn't love her; that's when it happened. I know:" Mary spoke as if she were reading a new exciting text within hersejf. "When love is blighted, there's hate." 2

of Mary and her trouble, he says, in answer to her assertion thet she is not wonderful or else she would not be in trouble, "Asoul can get in trouble because sho's brave. That's you. A soul can get in trouble because he's a coward. That's me." 3

He then reveals thet once he was an honest man, human and sympathetic. Sarah, soon after they were married, began to insist on his making more money, even if it meant his being a rascal in his dealings with his fellow men. He had

1. Bridegroom Cometh, p. 425 .

2. Ibid., p. 425 .

3. Ibid., p. 424 . 
never thought enough of money to be dishonest to get it, but when his wife insisted, he threw principles to the winds and sold out his self-respect. The joker vas that after he become the fellow who was getting rich in any manner possible, his wife refused to live in the new house he wented to build for her, refused to touch a penny of his money, and mede her own by taking boerders. She hed nothing but contempt for him. Their lives beceme meaningless, and he had no respect for himself until Mary, in giving herself to him, restored some of his belief in the men he could have been. Wary told him:

"We're both no good, Luke Carns. I won't let my husband give me anything better than a swell apertment. You vouldn't let your wife give you anything. She was decent enough to refuse the swell house."

"I loved her well enough, Hary."

"Don't you dare use the word! Sarah's better than you, becouse she loved you. Willem's better than me." I

"That's why we came together," Mary kept on thinking aloud, her hand in his. "God! a man and women can come together, just because they have no love!"

ife let her hand go, and his mind went back to his wife. The girl was telling the truth. He had never been tender, never called for serah's tenderness. Now he sav them both - - their sons grown away or dead.. . go down the hill together towerd death. Tenderly. - We're old. But we can still be decent. As from a gray gloaming with sarah at his side, he looked at Mery ablaze in her youth. A world he hes left. - But there is another world. At that instant, for the first time, Luke carns acepted his life: his heart wes full of tenderness for Sarah. 2

1. Bridegroom Cometh, p. 426.

2. Ibid., p. 426. 
Wary has given to Sarah carns her husband, and she has the plessure of seeing them together, contented and hoppy, before she leaves clermont.

Hary writes Willem from Loomis Lake a few weoks later that she is leaving him. In the letter and later in talking to him, she gives as her reasons that she could not live in his rorld; it was poison for her; it was choking her to death with loneliness; and she did not love him.

Willem, pathetic in his deep love for Mary and in his greet need for her, realizes that he cannot hold her longer. From the depths of his sorrow, he tries to make financial arrangements for her, but she refuses his money.

Years later, after she has tried many jobs and has failed, to some extent, even with the Labor Novement which she has joined, she meets David Warkand. She is ready for him and his love. For the first time she feels herself Waking. "Mary knew thet to wake was to love. To make and to love were one." I

This coming together of these two persons points the way to a marrigge of fulfillment and happiness.

\section{Conclusion}

Warriages, according to WaIdo Frank's fictional presentation, are of two kinds: frustration and fulfillment. There are many contributing factors to both of them, social as well as personel. The physical aspect of the merrigge 
relationship hes little to do with the success or the failure of the unions. Although he devotes much space to descriptions of the physical phoses of marriage, he uses this high sensateness as a means of getting into his funamental philosophy - - the importance of the psychological element. The recurring psychological themes which the author sees as bringing frustration are expressions of his ideas concerning women and their relation to men and to social conditions.

The havoc that is wrought by strong individual wills is emphosized. Hortimer end Leile Crene in Summer Never Ends get a divorce ending their unsetisfectory merriage, and Hortimer's thoughts as he looked ot her express the guthor's ideas concerning wills.

She vos shut from him, she hed always been shut from him, she in her will, he in his mill. There could be no marriage of wills, he figured. He thought of his parents' merriage. They had both believed in God, believed thet in marrying and bringing children to the world they were doing God's will. They had submerged their own wills. It had not been a perfect marriage, far from it: but it had been a marriage! I

Warriages without love and sympathetic understanding cannot bring happiness. Crane, in thinking over his life With his wife, s\&id:

He had been in love with his wife; but it seemed to him now that this meent to love himself . . even es Leila hod loved herself in love with him. And during the years of

I. Frank, Waldo, Summer Never Ends, pp. 88-9. 
disillusion after he knew Leila was lost, he had had his love affairs - not many. He vas a satisfactory lover, the women made that clear: not for a moment in those episodes had he loved the romen! 1

That romen often demand so much in the way of social position, luxuries, end financial security that men sell their principles for money is portroyed in several instances. This is typical.

And although Leila knew she hod done the managing: the weaning her husband away from labor to corporation practice, the making of the right set in Murray Hill and Huntington, Long Island, the selection of the children's schools, everything. . . she blamed the failure on crane. Crane sat with his nervous cigarette at his desk, waiting: he had loved her fairly. . so it seemed to him, and he had riven her everything she asked for. It was a puzzling modulation. She had married the "tribune of the people"; and, deliberately, she had destroyed him. She had wanted a husband earning big money, devoted to her ways; and when she had got him, she despised him. 2

Husbands and wives who live solely for each other without universal love and without bringing into their hearts a full understanding for other people cannot hope for satisfactory merriages. This course often leads to a refusal to have children, and Mr. Frank believes strongly that children are a necessary part of any happy marriage. The love of power, machines, end money spread chaos in the homes and prevent those who are slaves to such things from becoming an integral part of their homes and families. Fear, which is often present in the hearts of

1. Summer Never Ends, p. 15 .

2. Ibid., p. I2. 
men and women, is a product of our power-machine servitude, and such fear corrupts merriage relationships and brings frustration.

Women who, because they have not received from the men the respect, love, and moral security which they have a right to expect, hove become restless, dissatisfied, and empty. Frenk says:

Women are most clamorous for "rights" in londs where culturally they have counted leost. Witness England or the United States, where for all her liberties romen is spiritually sterile. l

He portrays several women who are intellectually strong and desirable in every respect, yet they hove been unable to find men who were capable of bringing out the best in them.

These contributing foctors to frustration are social and psychological. They are problems that can be solved if men and women, starting at the beginning, will bring about a change in their omn lives and then attack the evils existing in modern society.

There is a way to insure marriages of fulfillment. When Americen society becomes composed of integrated persons who are Whole - persons believing in God and incorporating in their lives a love and a concern for universal mankind, and when these persons, integrated in their cosmos, merry other persons, then the union will be one of absolute 
fulfillment. Such a merrige, permeated with that greater love, which not only includes the husband and wife, but which embraces all peoples and life itself, will be a source of complete fulfillment, dispeling all doubts and chaos. 


\section{PART II}

CHAPTER III

MOTHERHOOD AND YOUNG GIRLHOOD 
Two aspects of Waldo Frank's treatment of women remain to be studied: those of motherhood and young girlhood. Since there is less material on these, I sholl analyze both of them in one chapter. An analysis of the relationship of these types to the problem of sex and marriage will serve at the same time as a correlsted recapitulation of his treatment of women.

\section{A. Modern Hothers}

The outstanding ospects of Waldo Frank's treatment of modern mothers are: the mother and child relationship, the longing for motherhood, end parental influence. The mother and child relationship appears in Unvelcome Man, New Year's Eve, The Bridegroom Cometh, and The Death and Birth of David Markand. The longing for motherhood is seen best in The Bridegroom Cometh and Rahab. For a discussion of the parental influence, I shall use New Year's Eve, Deeth and Birth of David Horkand, and Summer Never Ends.

\section{The Mother and Child Relationship}

Waldo Frank's first novel, The Unweloome Man dwells at length on the mother-son relationship. In the beginning 
the emphasis is placed on Quincy's need of his mother's understanding, when he, os a little child, finds himself in an alien world. She recognizes their effinity and knows that 2 uincy and she are kindred spirits, but she deliberately refuses to acknowledge this for fear a close relationship with him will raise a barrier between her and the rest of the family. This denial of auncy's inmost need by Sarah, the mother, causes him to build up, as a defenso mechanism, a feeling of resentment against her that turns to sheer animosity.

But his looking up and within himself

made it as if Sarah and her last-born had

been alone.

She was seated on her favorite cane chair. At her knees stood Quincy, half leaning against them, his hands in hers, his heed on 8 level with her eyes. And so, facing each other, they remained. There was a pathetic similarity between this aging woman and this growing boy. Their faces were long and drawn; their heads were generously moulded. The eyes of both were a deep blue-grey that reminded one in her of faded violets, in him of violets that were fresh but in a shadow. Even their mouths were alike - large, tenderpointed, mobile. And at this moment, there played upon them tremor like the echo of a single pain.

Sarah shifted her gaze. To her, this searching intercourse between them had become almost unbeareble. It was as if, in this deep sympethy that had annealed them, lay infidelity toward the others to whom she was attached. For quincy could not be the only one. In the rapt intensity which drove his spirit toward her, and in her impulse to respond just so intensely, just so wholeheartedly, it was as if, easily, it might be brought about that there should be no others. But such a blessed 
gift was not ordained for guincy. Sarah repulsed her possionate inner gesture of bestowal; she beat down this mother in her which threatened to clasp Quincy to the exclusion of all else. She summoned her sense of duty, her social sense, her common sense... And deliberately, coldly, though she knew not the full nature of her act, she broke this blinding, seething current thet threatened to submerge the pair, one with the other. 1

When quincy is grown, and the opportunity for winning him no longer presents itself, Sarah tries to tie him to her by arousing his sympathy for her, by telling of all she has done for him, and by endervoring to keep closely affiliated with his affairs. None of these methods serve her purpose, however.

Sarah realized when Quincy was a baby that the children could never take the place of her husband nor satisfy the roid in her life when he coldly withdrew from her. It was to regain the loving regard of her husband that Sarah struggled, and Quincy could always feel the presence of his fether come between him ond his mother, even when they were closest.

The mother and son relationship is found gain in Mrs. Teess and Willem in The Bridegroom Cometh. Hrs. Taess has him chained to her so firmly that even Wary, his wife, cannot break the hold. When Mary suggests to Willem that they move from his mother's into an apartment of their own,

1. Frank, Waldo, $\frac{\text { The Unwelcome }}{\text { and }} \frac{\text { Uan }}{\text { Co., }, 1917)}$ (Boston: Little, Brown 
"He lay infinitely far away, beside her;

his mother his mind, his mother the skin of

his body. Underneath she must find what is not his mother. . . . . She moved her hond upon his. He moved his hand aray. He was his mother's child, petulant, not yet hers... to be created hers." 1

To satisfy Mary, he consents to more, but he promises his mother that he will come to see her from work each evening before he goes home to Mary for dinner. The fact that the drive is a long one and out of his way home only serves to shom his devotion more. He says to her, "I am your boy. I will never forget." 2

Mrs. Taess keops him by makine him feel sorry for her and by leading him to acknowledge what a monderful, selfsacrificing mother she has always beon. Mary sees her in a different light, however, and it was the breaking of an antique dish by the servant Djuns, that led Mary to see the real Querida Taess.

Queride stared at the disoster; her eyes gorged on it and were young with an open hatred.

This woman taking the dish (Ouerida Taess) loved no human being! . - No love for Lilie, no love for Willem! . . She loved not the lives of her children: what she loved was a death, and her children's place in it. . . 3

Mary know ot last that this mother was "a monster", 4 a person whose ife fed on death and who would break her

1. Frank, Waldo, The Bridegroom Cometh (New York: Doubleday 2. Ibid., p. 325 .

3. Ibid., pp. 318-19.

4. Ibid., p. 319 . 
children. This led her to say to Willem "there eren't any mothers in the world". 1

Helen Wrakand, in The Death and Birth of David Markand, has three smoll children, and the problems she faces in rearing them are felt keenly by her. She realizes, too, that their coming hes celled for readjustments between her and her husbond. It is here that we find Waldo Franl presenting the duties and obligations of motherhood in a broader sense.

The children were born and they vere the beginning of a rift in which her mind, long slumberous in her husband's flesh, must stir again. It wos not that their love weakened; even their physicel need for one enother, after a pause, returned with a new deep wonder that dimmed the glamor of the first year. But Helen was no longer perfect in her man; there vere the children, the children. They celled her forth from her Devid, led her in myriadly brenching ways to efforts, plans, fears, joys, that were not David. She vas still close to her man, far closer than to her chiloren; there was no moment when she did not know that she loved him and needed him more than she did them. But theirs mere the innumerable tentacles of the hours. Into the intricete everyday web of the ties of her children, her husband could not enter. He was not even aware of them and of their denger. Each day he went to work, returned to romp with the babies and to do the little chores she put into his way in the piteous effort to bring him inside the werve; each night, he loy with rer. Avail-less. That perfection, Iuminously white, of her and him elone, not so much in the world as making it, was gone. And Helen learned that children were no substitute. Though she diapered them and fed them and bathed them and took them walking, and sang to them, they rere themselves - - spreading each day ferther into their om 
dimensions. She must follow them to protect and sustain them, she could not make their world her own. That world was hers, not in the joy of self-fulfillment, only in the strain of responsibility. Was she an unnatural mother? Then she knew:- New York and America are full of mothers like me. Came an illness and a resolution. She hired a competent nurse, buying her freedom. But it ras a delusion. She lesrned soon enough that freedom was nothing without fulfillment. I

It was then that Felen became converted to the catholic

faith, and she developed a different philosophy concerning them.

Helen was happy. Her world had

meaning. . . Her children had meaning.

She could love them et last without torture (and she knew that no pain, unless suffered consciously for God, was good). The burden of Tony and Wartha had been well nigh unbearable to helen. They were hers, how could she be sure that she was right, doing and thinking $\overline{\text { ight }}$ at every instent for them? Now, thonk God! she knew they were not hers; she understood the insufferable pride in assuming they were hers. Had she created them? did she understand the mystery of their blood and eyes? God had worked the miracle of their life within her body, and she had borne them. They, like her own life, were lent unto her soul a little while, to bear es bravely as she might. If she did well, the virtue ras not hers; if she foiled, although she did her best, the same Grace that had given absolved her. To be responsible in the actual flesh for her chilaren had been unbearable, she knew, because it was a lie. Could she foretell every possible wagon in their poth, every possible germ, every possible poison of word or gesture that a pleymate might spread? Her fury of responsibility assumed that all this, and no less, was expected of her: and it was a fury of pride. Now she was light. Her children, like herself, were in God. Life was inscrutable, at times

1. The Death and Birth of David Merkand, pp. 55-6. 
glorious, et times cruel. She tried to make

it beneficent for her children. This also

wes pert of life, pert of their life; thet

they should have a mother who did all she

could to make them strong and clear. But the

ultimate as life itself, and its creator was God. I

One does not feel, however, that Helen has become a better mother; in fact, it seems os if she has shifted her responsibility to God, and she denies the very problems that motherhood should bring. I meke this deduction because she never seems to srow into a mother-person; she derives no fulfillment from the fact that she is a mother. Tony, the little son, dies; she admits that the young daughter, Martha, irritates her and that she does not have the right kind of love for her. The last picture we see of Helen is when she is trying to get the baby out of the room in order that she may be alone with her husband's letter. Joining the church did not make a better mother of $h \in r$.

These mother-child relationships which I have discussed are unsatisfactory; they bring happiness neither to the mother nor to the child. There is something definitely lacking, and this lack is felt by Mary Donald as she works among children and longs for them. This leads us then to the second phase of our study.

\section{Longing for Hotherhood}

The yearning for children comes to liary in The 
Bridegroom Cometh as she works for a children's protective agency in New York.

- Children. Mary completed her finel visits late, and returned to the hotel. As the sun drooped, the heat rose. Her room, facing east, was cool; a breeze breathed moistly in, auguring thunder and showers. Wary undressed and bethed ond lay on her bed. children . . It was not a voice, not even a thought: it was the stir of an organ in her flesh dying at the surfece of sense in her fatigue and the good ease of her room and the memory, inexplicable peinful, of hartha: chilcren . . Marthe. . nothing. Mary wes sorry she had not brought her good or gendie dress for dinner; but she comforted herself, no one looked ot you in this hotel whose steel machine was featly fended in cretonne and pastel courtesy. Children . . She dined well, and went straight to bed and to sleep; the fatigue of the day's height and yesterday's depression overwhelmed her. And still beneath her ease, the viscerel voice: children.. I

As she tried to write her reports, "all she

remembered was the faces of children . . . And always

the feces of children.. - always her orn body." 2

She liked her new job because it gove her an opportunity to care for the children and be with them more.

When she was with her children, she forgot all else. . . the city, the echoed burdens of the morld, herself. It was a sweet intoxication to dwell within the children, share the play and fears of children, and yet have power to guide them, even at times to make them hoppy. Children, she felt, were o vorld. And she loved it. tiad someone forced her to declare what was wrong with the other world: this sultry, sodden summer, these sullen people,

1. The Bridegroom Cometh, p. 256 .

2. Ibid., p. 257 . 
she would hove said it simply, It's too different from the children. Wany of the little ones viere hard ceses: they came from asylums where no love had mellowed their animal egoism, from boarding homes where their little lusts and ugly habits were ingrown like cencers. Often, they vere unruly, perverse, but Mary wes not troubled, because she saw the problem from within, doubly: from within the heart of the child mich always she found sweet and from within the adult world which she blemed for all she found bitter. 1

Yet it was intoxication. - and each night the amakening. Eech night, the children were not there? her touch upon their lives led to no hold. The sweeter she felt tem, the closer saw them (every child she knew became for her a passionete problem), the
more dread the seperation. 2

$$
\text { "I'm selfish," she soid to Willem. "Thet }
$$
I make a child a little heppier does not make me hoppy. I want to give them more... alweys. And because I can't, I want to give nothing." 3

Her nights, sobered from the day's sweet care of children, grew sad end herd. Soon the melody of the children, bittersweet, made all she felt in life its accomponying music.

This yeerning for children is not satisfied in hary, for, hoving merried a man whom she does not love, she refuses to have them.

Wrs. Luve, in Rahab, having been driven from her home and her baby by her husbend, grieves deeply oner the soperation, and her longing for her baby is at times almost

1. The Bridegroom Cometh, p. 281.

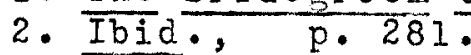

3. Ibid., p. 282 .

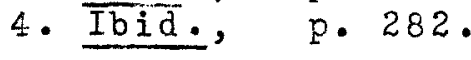


unbearable. The pain she felt as she moved away from Edith on the train was "one pain. - one moment. Pain. She sow that it was not a thousand pains, weeping in gray wings mistily about her. She saw that it was Life". I The depth of her longing may be gethered from these:

Edith my child: Soft hands upon my orms, soft lips upon my mouth biting me with such sarage softness. Edith? $0 \mathrm{my}$ soft lare whom I held all about me. . who held me all. You are gone.

- I shut my fece in my hands and you are about me, my Baby. Only you. Your hands and your hair and your little mouth. Edith, Edith..

-I shut my eyes in my hends and you are about me, my Baby. I am a baby with you. Our flesh is one: our hands are one like petals entwined in flower. 2

Such deep emotions as those of Mary and Mrs. Luve in their longing for a child are not found in the mothers who heve children. Perhaps Helen Markend's words were quite true when she thought "how she and Devid, and soon their children, rattled about in chaos!" 3

Waldo Frank's belief that the feelings which parents have for each other will determine to a great extent the kind of dispositions and cheracters their children have is one of his recurring themes. A study of his fictiongl treatment of this phase of the problem will be helpful.

1. The Bridegroom Cometh, p. 282 .

2. Rahab, p. 13I.

3. The Death and Birth of David ilarkand, p. 60 


\section{Parental Influence}

Waldo Frenk emphasizes the fact that there will always be something lacking in the children who ore born of parents who do not love each other. He goes even further by expressing his belief that what parents are and how they act have a definite influence on the children. The positive side of this psychological truth is to be found in the description of the place David liarkand held in his parents' lives. In describing Devid's mother, he says:

Her husbond was a wise man of many talents, abused and unmastered; his ogile mind served to retionalize his possions; he lacked the staying power and the steadfast light which he loved in. Martha. That love, and her love for that love, were incarnate in their child without whom they would have flung off from one another, as their minds often flew and their moods. Devid held them; Devid was the life deepest and most real in them: their desire.

And Devid's flesh now knew how his childhood's being with his perents had been good, strength-making. The storms he hed witnessed of his father did not disturb him. For his fother's eyes were tender. He took him along, when he hunted for mushrooms; he romped with him under the trees of their garden; he let him puff his pipe and wes proud when the child did not sicken. At times, like one child with another, he yelled at him, even struck him: which, as one child of another, Devid understood. And the eyes of his mother, Whatever storm brooded or burst in the house, were always full of peace when they beheld him. Until her death, even after her death, her eyes beheld him... I

After his father died, his mother and he were closer

I. The Death 8nd Birth of David Markand, p. 147 . 
together than ever before. All his faith and goodness come from this relationship. In Dark Mother, David has come to New York to live and work, having lost his mother sometime before. He thought of her:

She had died thet liey. Until a few years ago she had tolked a great deal with him. Their talk dwindled. The open space of their fer words became an esseful place for him to lie in. He withdrew more and more to it.

He loved his mother. But his love remoined at the depth where it began: one with his needs when he wes an infant and she nursed him, a child bruised gganst the morld and she consoled him. She wes gone: but the glow of her motherhood still warmed through his life. Like his love, his loss was mute. He did not know how deeply he loved, he did not know how deeply he had lost his mother. 1

This reletionship that David knew with his perents

is in his thoughts as he tries to discover whet is wrong with Harold Gore and his mother, Deborah. He and Herold hove some words one day when Harold tells him to legve his mother alone and not come near her again.

But he held on; and with his rege mestered, came now a deeper vision. - The boy has never grown up; he knows it, he resents it, he blemes and hates his mother for it! Why? She was a Toman knowing, in the dim wey of all of us, there is a world and her own smell pert in it. Why had this normal knowledge esceped her son? For he did not know his olace in the world: that was the ceuse of his resentment, his jealousy, his pride. Tas it that he had not hod hic place os a child? The warm central place within the world of his mother? seeking now vainly in the world of men what his child

I. Frank, Faldo, Dork. Mother, p. 6 . 
soul neecied? The anger wos gone. Wiarkand knew that he had had his central plece vith his orents: Tony and Marthe had it. From it, perheps, alone might come to a men courage and pover to go on vithout it, in in the world of adults.

Warkand looked at the two, and there was another presence in them both! semuel Gore had molded the youth and had molded the woman. Her dark spirit against her man Workend felt it! - was in her love for her son. Out of her lean, supple body had come this youtr: the color of their skin, of their eyes and hair, was one; but had come also the dark coil of her spirit aginst the father. They ere one, ell trree, bitterly wound within one enother, meking their own world. I

Deborsh's married life, from tre dey she beceme bride, was one of terror, fear, repressions, and nisunderstandings. Her children hod not been born of love, and all died but Harold. Wer, as they quarrel, one sees the effect of such a marrioge on the child:

". I ain't ashemed of my life." (Deborah to Harold) He understood the slur to his father. Never once did she say a good word of his fether.. - or eny word... she never linked her life with his fother or with him.

He recoiled, dimly understanding that her fear mas anold fear, older than he; understandino goin the slur, in her fear, on his fother.

"This I'll tell you," Deborah clasped the edre of the table with both hands. "Do not strain too hard my love for you."

"You don't love me. You never loved me."

"I loved you."

"You lie."

"I don't Iie, Horold. But we are strengers.

1. The Death end Birth of Devid Morkand, p. 132 .

2. Ibid., p. I59. 
When you are like this, we are strengers."

"You lie! You never loved me, because

you hoted father. That's why we are strangers."

She looked ot him silent.

"Go ahead, deny it!" He was half weeping.

"You don't dare. Why if you love me, don't you say it?"

Her geze at her son herdened for she knev

that she loved him, and that she must hate him, a. 1 s. 1

Summer Nevor Ends presents a similar problem of parent-responsibility. Judith swift hod married a men Whom she did not love fully. Her son was wild, unstable, and decadent. She felt that her job was to look after him and try to reclaim him through her love and kindness, since he had been poisoned by her feelings for her husband. She says to Wortimer crane, the man whom she had loved in their youth:

\footnotetext{
"Larry is a part of my marrying Grey. Thet was the irresponsible act. And you were in it."

"Go on."

She tools his hand, held it pensively; then dropped it. "There's nothing more. It's not easy to say - yet so much herder to know! I know it, and Larry feels it in me; that's inportent and more hopeful for him then all your reasonable methods. If Larry comes to know it himself. he's saved." 2

Then Mortimer sums it up:

"I was afraid of your love for me and of my love for you. You've told me thet, and it's true. I felt no responsibility for us.... for the life between us. To get on in the world was more important. That's what you're saying. And from that irresponsibility of mine
}

I.- The Death and Birth of David Narkand, p. 160. 2.- Summer Never Ends, p. 193 . 
toward you, came yours. . your irresponsi-

bility in marrying Gray. Then, Larry..." 1

He applies the reasoning to himself, ond, because he acknowledges that fear was back of his love for his wife, he sap his own children as the product of fear. The imperfections in both of them are but the offspring of the flaws in his life with his wife. Judith does not see her cese as hopeless, however, but she knows for a certainty how to deal with her son.

"You think it's wonderful of me not to be more upset by whet happened tonioht. It's that I know, dear, that love will work, love will win becase nothing else works, nothing else wins!"

The best example of the influence which a loveless marriege has on children is to be found in the play New Year's Eve. In each of the three couples, one party loves someone besides the person he or she is married to. Yet they live together and have children. Something is wrong with all the offspring - they are social misfits or disintegrated humans - except Alan Macshane, the only one begotten in love. His mother, Laura, had permitted herself to have one fternoon with the man whom she loved, and Alan was their child. In direct contrast to all the other children, he is loving, kind, understanding, and intelligent.

1. Summer Never Ends, p. 194.

2. Ibi $^{\mathrm{d}},-\mathrm{p}, 19 \overline{4}$ 
Leura, as she sees the wreck of all their homes and lives, decides she is to blame because she did not leave her husband and marry Albert Benison many, many years 8 go. She says:

For that ruthless act, behold the issue. Albert merried Ian in desperation. Albert hurt Nan. And the hurt of Nan has passed to Trubody to Holt. And the hurt of $N_{a n}$ and Albert turned to poison in Cleo, and married with the poisoned soul of Leurence. Laurence, poisoned in our home. And Laurence and Cleo dead. And Trubody is blinded. And we are here, again, alone.. What will you do with me?

The hurt of the child in the home without love is typified in this conversation between Trubody, the boy who has come beck from war blind, and his mother, Holt. He told her he had volunteered because war was an escape from home, on opportunity to get away.

"The situation is not without its humor, mother dear. To protect me, you stayed. Your mother-sense it was that drove me away into that shambles.

Holt: I am the one who blinded you. Trubody: Tryino to blind me Holt: Don't!

Trubody: To your own misery, married to a fool, A vein end sounding fool. Werried to a cericature of your dreams. Yes, mother. 2

Later:

Trubody: You suffered. That is all you had to do with my birth. I should have stayed with you. I knew how my enlisting would hurt you. I was glad I was not of draft age, so that I could enlist - so I could

I. Frank, Waldo, New Year's Eve, (New York: Charles Scribner's 2. Ibid., p. 70 . 
hurt you. I wanted to blind myself so much. To my love for you; to the humiliation of my fother with his hideous gestures; to the irony of Lucy - flashy Lucy, being the child of you. Mell, I succeeded. Blind -

Then he continues:

You wanted always to serve beauty. You want to still. I see you, my mother. Long ago, perhaps, your eyes were open to the truth of father. Still, they dream. .

Holt: For you. When you were born, already I knew how wrong I had been in him. Only your life made me dare face that death. I

Laurence, in talking to his dad, says he loves cleo because there is nothing else in all the world to love. When he orows too rude, Wachene reminds him thet his mother suffers when he acts in this way. Laurence replies:

Don't make that appeal to me. Why is she incompetent as a mother? What right hos she to bring from me what should be notural or not at all? Is she responsible for what I am? or not? If not, let her clegr her mind of me. If so, then whatever I am, she hos her deserts... ${ }^{2}$

Wocshane admits: Mother is not happy. I have given her what I had. She is not happy. That is the meaning of failure. Grace is unhappy. Ily daughter. Thet is the meaning of failure. Larry is morbid, morbid in love of $a$. morbid girl, morbid in hatred of us. That is

Alan is getting at the root of Laurence's trouble when he seys to his mother:

1. New Tear' Eve, pp. 70-71.

2. Ibid., p. $\overline{84}$

3. Ibid., p. 89. 
The house! Thet is what has sickened Larry! The rords of this house. There is something wrong in this house. I

But his mother sees them all poisoned and filled with evil becouse the parents have murdered life. Definitely, Waldo Frank finds that modern vomen are deficient in the qualities that make for real motherhood. Leila crane, in Summer Never Ends, has no concern at all for her children and no love for them. The mothers whom I have discussed have let other interests come first, or they hove children who are miserable. David Markand and his mother are the sole exceptions. Mr. Frank is ever seeking the well-integrated person, and, as in Mary Donald, his characters are striving for personal fulfillment. It is striking, therefore, that he has not created a mother who is a person; that he has not presented the evolution of a mother-type who fulfills her destiny and becomes the integrated mother.

One of the cheracters in New Year's Eve expresses what Mr. Frank has implied in several instances and what he probably believes implicitly: "A woman who has felt nothing is a slave when she is a mother." 2

\section{B. Young Girlhood}

I shall give an analysis of the young girls found in Waldo Frank's novels first, and then I shall relate these I. Wew Year's Eve, p. 93

2. $\overline{\mathrm{Ibid}}, \overline{\mathrm{p}} \cdot \overline{5 \mathrm{~S}}$. 
types of girls to his presentation of the mother, marriage, s.nd $\Sigma e x$.

The novels which I use are Unwelcome lin, Dark Mother, The Bridegroom Cometh, and Summer Never Ends. The young girls in the first two are not important charecters within themselves, but they assume their ploce because of their relationship to the young men. One never sees them as separate individuals, and wr. Frank does not devote much space to a psychological analysis of their cheracters and actions. The sisters of quincy Burt in The Unrelcome Man are anglyzed briefly in their reletion to him, and they are seen through his eyes. The girls in Derk Wother ere presented through Devid's experiences, Cornelia Kennord being the only one whom we see through her own onalysis. Both of these books rere written during the Experimental stage of the author's career.

The last two novels which Mr. Fronk has written return geain to the young girl characterization, but there is a great difference to be seen in the manner of treatment. The girls which we find in The Bridegroom Cometh and Summer Never Ends are anelyzed and presented as individuals; they dissect themselves; other choracters sum them up; and the author helps develop them fully from psychological and sociological angles. These two books belong to the periods which I have termed that of Consciousness of the Ferson. Rhode and Adeloide ore contrasting cheracters in 
The Unwelcome Man. Adelaide loved her brother, Quincy, unselfishly and understandingly, but there wes a certain embarrassment which held them aport until auincy came to prefer Rhoda and her selfishness.

It vas the common mistake of most people to coll Rhode the prettier of the two. Such ere the triumphs of an eggressive soirit. For a though the younger (Adelaide) ras essentially the finer girl, her subdued nature shone forth bodly beside the obvious brilliance of her sister.

And meantime, near Rhoda, in rhose cold, perverse, spoiled besuty his ironic instinct had caused him to seek a haven, therc was another sister, yeornino for his companionship. But Adeleide's eyes trere diffident, and her way res quiet. auincy knew ebout her only thet she was in Rhode's groces, and therefore to be tocitly envied and resented.

Adelaide yeerned for her brother's love and confidence, but the deeper her feelings were, the less articulate she became, and it was Rhode, cold, proud, and indjfferent, whom guincy yearned to have as his companion. This conflict is seen throughout the book; Adeloide hes no boy friends and no lovers, while Rhoda is very populer. Khoda gets married, and re hove every reason to believe that no man ever discovered the true gold ridden within the reticence of Adelaide.

Some of her cherecteristics are to be found in Cornelie Rennard, one of the girls in Dark liother. The same motherliness toward her brother is to be found,

1. Unvelcome wen, p. 81 .

2. Ibid., pp. 85-83. 
eltrough it is much more pronounced in cornelis, and she penetretes much more deeply into the life of her brother than does fdeleide. In fact, Correlis is a second mother to Tom, and for years they are closer together in love and understanding than most brothers and sisters. He fills her life completely until Devid liarkand comes elong. Cornelis is a sculptress who hes come to New York to moke that her life's work. She has already won prizes end fame and seems on the road to genuine sucaess when Tom brings Devid to her studio. She falls in love with David, and thot brings about the eventual rift between her and Tom. Success and fame soon are empty rords to Cornelia. Her life end mind were chaos.

She had never needed to find the word for whet she felt toward Devid. Often, she needed to sey to herself in self-assertion: I am a women. Her life brought doubt of that. Were women supposed, like her, to live alone and rork, and heve no home, and have no one to care for? Her instinct despeired often of the life she gave her body and her mind. In protest, sometimes it would speak: am I a woman? But here was a harmony so deep it required no voice outside itself: in whet she felt torerd Dovid. I

How strange it all was, what an ironic time of it the world was having with its men and women! She had vearned to escepe in order to be an artist. She hod left home, risked life. She and Tom hed starved, while she pursued her dream. Here she wes: Cornelia Rennard, sculptress. And ashes in her hand. But what was more than stranee: she did not seem to care. 2

1. Frank, Waldo, Dark Wother, pp. 313-4.

2. Ibid., pp. $\overline{328-9}$. 
When she and Tom learn of the death of their fether,

Tom remerks:

"Father was a happy man: he hed a plece to go, from this desecrated vorld. Fether ves a strong man: he hed his God. Where is our God, Corneli.?"

(Then he answers himself:)

"We have no gods. We have lost the old
one. We have won no new ones." l

Then Cornelia tells him that they both ore unheppy.

"Are we that?" he asked her. "Have we

the strength to be unhappy? To remain unhoppy?

Oh, how I wish I could believe that!" He was

grasing, both her wrists. He dropped them.

"No," he said. "It's a lie. We ere

nothins. We are not even martyrs. I with

my Lew - my successful rotten Law. You with

your paltry, remunerative Art: We are on the

way. Something is on the way, through us,

perhaps, through the wilderness of life: $2^{\text {We }}$

are they who shall fall by the wayside." 2

Unhappy Cornelia, the loving, the kind, and the understanding girl, in order to save David from Tom, gives him into the arms of another oirl, and she commits suicide. It is a case again, like Adelaide, of just such a rirl not being desired at all by men, and their life lacking fulfillment.

Clarice Lodpe, in Unwelcome Man, is the girl Quincy had met and liked when sho was sixteen. She entered society the next season, and ouincy did not see her for several years. She is now a young troman, hard, cold, blese, but for Quincy, this night, she can be her old, girlish self.

2. Dork Mother, p. 318 
Mr. Frank then gives this criticism of society and girls:

The City's intricate machinery for bringing about what is already there - an engine for making paper leaves grow on real trees - creates 2 pathetic duslism even in its girls. It provides mell that the gulf of after-marriage between their natures and their positions may be sure to have had time to widen. Already in their choice of friends, girls know the limitations of the laws that bind them, develop technique of evasion, straddle two mounts in order to ride two ways. And if leter, as a. clear due of this, they are torn limb from limb, mon with his insect $v i s i o n$ blames their desire to ride, instead of the false direction in which they have been placed.

It was with some such canny calculation that Clarice welcomed Quincy. She knew well the sort of man whom she must ried. She ras able to judge how his capacity for filling certain mejor needs of a conventionalized life must unfit him for many pleasant metters. She wes well-prepered to split herself in two, dally with Quincy - while she vent on hunting for a husband. 1

Clarice despised the life she lived, and she had

become completely disillusioned. She loved all the things Quincy hod once stood for, but she knew she must persevere in tris world of hers and that she was willing to do so. Thet was why quincy sensed in her "the strange edmixture of tenderness and flint, joy and detechment, which clarice displayed". 2 He sar her, intellectually radical, emotionally set and conserved - more than existing, living with a clear efficiency and a firm conscience!" 3 she had completely mastered oll her emotions until they served her purpose well, but in so doing, she had become hard and

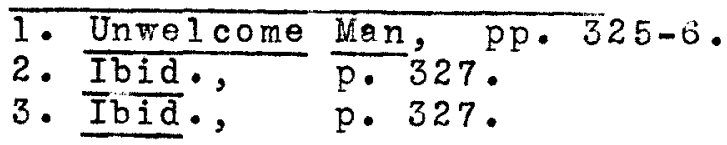


demanding. When she is rebuking him for not utilizing all his talents to become sometring better than he is, he asks her what she has to give him to help keep him real except a set of rules; she has no answer for that, for she has no strength to give him. She had "no power to bear and no heart to quicken" I his great need if he were to becone a person. Clerice needed, as much as he, to become o real and a live person, but she was not willing to crucify her mill until she could help them both chenge their lives. This same kind of girl, with a few variations, is to be found in Lois Deane, one of the young ladies in Dark Mother. Dovid, her cousin, thinks for a long time that he loves her, and while he lives in the Deane home she, sixteen and serenteen, and he, twenty, play around at being in love. David would heve been very serious indeed if Lois had responded just as serious $1 \mathrm{y}$.

Lois is very likeable, friendly girl, and she possesses the cheracteristics for becoming a truly happy, well-integrated person. When David kissed her first, she answers his questions by asking:

"Do you think, if you hadn't been nicer, and cleaner, ond everything, I'd let you kiss Her liked her intimacy. It flettered him. He did not wish to tell her of his work at wr. Devitt's, end how easily he might have stayed there long and forever. And she liked his

I. Unvelcome Nan, p. 370 . 
-reticence, feeling its power. She liked the veiled promise of plessure and strength that he suffused from all of his big being. It frightened her. I

When David loter gives her a kiss of passion, she

becomes angry.

Something storted up in his breast and beat against his breathing, hurt him. Not the denial of the kiss. It ras the sudden pierce of her insensitiveness. She hed not cered to understand how he cared for her. And when he hed longed for her mouth, her mood had not chenged!

If only it had: If only she had been moved though it was in denial.

He had ot times believed he saw her little body stir with pession when he ras near her. But so faintly, so containedly. Wever in doubt of her control. Something she tasted in exquisite moderetion ond enjoyed. In her deniel she wos cool. It was as if her hunger for e closer kiss were a question answered in her cetechism: one she knew all ebout; one she hed learned the answer of by rote.

There she was smiling, chatting. She had already forgotten. 2

It was this way throughout their courtship. She

deliberetely denied herself the feeling she might have had

for David because she had been trained to look for something

else from society. The same thought which was expressed

back of clarice's philosoohy is found in this:

Seated at the wide round table with wuriel and her mother, she instinctively inquired into her own future freedom: and in this mood studied them. She studied their dress; she stucied their activities. She absorbed their judgments and their plessures. She was sixteen. A spirit of gayety and candor danced in her heart. But she had no

1. Dark Hother, p. 60 .

2. Ibid., pp. $92-93$. 
knowledge to build a mansion for it: to trein end cherish it: to give it weapons wherewith to confront the world. It was dancing, this unblemished spirit, dancing itself to death. For it was the deughter of the sun, and it breathed no fresh eir; it had been born careless and freil and all about it walls of convention: it was starved and forced to feed upon itself.

Lois knew alread the inwerdness of marrigge. There wes much talk of this at the luncheon table. She had the right contempt for the girls who married unmoneyed men for love: for the men who risked their future - their finances - in alliance with unmoneyed girls:

And Lois knew elreedy the inwardness of friendship. Wuriel and her mother had friends. They kissed them and flattered them and entertained them. At the luncheon table they discussed them. No one but was a tissue of deceptions, of selfishness, of deceit. Their morals were lergely obstacles they were forever dodging. They firted - with fops or fools. They angled - for goldfish. They were miserable at home. One ras none too anxious to to heve children. One wes none too faithful to her husbgnd. All of them were none too good at $a 11$.

Devid come to realize thrt Lois would never let herself cere for him, and he eventually gets over his leeling for her.

The presence of wuriel and Lois fretted his nerves: soiced them; teunted them. But if their lives, their thoughts, the gay deckings of their bodies called forth sex, also they stifled it. Devid wondered if it rould always be so, even when they rere merried. For 8 reason he could not name he decided he would not want. to be $a$ husband to Lois. There tas a curious contradiction in these girls: something counterfeit; perhaps

1. Dork loother, pp.77-78.

2. Ibid., $\mathrm{pp} \cdot 78-79$. 
something thworted. Dovid once saw a great red flower - hurjel's in $\theta$ vose on her toble. Thinking of other things, he smelt it: his mind went rushing towerd it, finding it odorless. He crushed it. He had never folt the lesst impulse to crush a fragrant flower. Wuriel and Lois vere roses, but they had no perfume. He thought, if he held such lover, he should rant to crumple her. It might mysteriously be a way of heving setisfaction. Living in the house with Muriel and Lois, he found they sharpened his senses, yet blunted his will: heightened his needs, yet drerfed his power to get them. 1

Along these seme lines of choosing husbends that ore economically satisfoctory, we heve the exanple of liarcia Duffield, in Dark Mother, who hes decided to merry a man nomed King beceuse he is wealthy and con pay her mother's debts. She loves Tom Rennard who comes to her to beg her to marry him. They heve had strangely satisfying intimacies, but Tom had put o stop to it becouse he could not afford to marry poor girl. He now tolls her they will manago somehow. Narcia then admits she wonts him but will marry King. Then, she seys that Tom can be her lover, an antidote for the husband. He cen be her adventure - her relogse from prison, end that will moke her marrying King bearable.

Dovid Mrrkand meets Helen Drindre, end Cornelia urges him to go see Felen. Soon, David feels that he loves her, and he, osks her to marry him. In The Death and Birth of Devid Markend, we find that they do marry, but Derk Mother 1. Frank, Faldo, Dark lother, po. 118-19. 
leaves them just es they become engoged. Helen is 2 serious, hardrorking girl who is o student in medicine. She intends to employ her science in expert rork among the children and mothers of the city.

"She wos et once lovely with youth end indestructibly firm with a quaint mothersense. Her stalwartness wes about her girlhood, protecting it, as her strong full body was ebout the dance of her eyes.. . She Tos steady; her thrust in life was sure and $\operatorname{lon} x^{\prime \prime} 1$

Warthe and Mery Doneld, from eorliest childhood hed been utterly different in disposition, although they were twins. Their childhooc and young girlhood hed known no pleasures end many deprivations. Their father and stepmother believed in teaching them about christ and letting 9ll worldly comforts go. Merthe wes sullen, herd, ond cold. She knew exectly what she wes going to do in life, and she never permitted anything to ceuse her to deviate from her course. She simply paid no ottention to the discomforts of her home, for she knew she would be there only long enough to go through school and get her a job and get out. Then she met Sid Hervard, and from then on no boys interested her. She rented Sid, end she weited until she could oet him. She was selfish, and oll the religious teachings in the world would not have affected her. She absorbed none of them.

1. Derk Mother, p. 337 . 
Mery was sensitive, loving, and rood. Both she and Wertha had to get part-time jobs as soon as they could, end they never had either clothes or the pleasures that most girls hed. Wary became the mystic--the seeker; she was deeply religious and craved love from those whom she loved. These quotetions will show the difference:

Here is the key to Martha. She accepted coolly the cruel strata of luxury and toil in the hotel, becouse her hunger was in another world. Similarly, she managed the boys, fendine off with esse their lusty, clumsy passes for her honds, her mouth, and without anger, without judgment, because hers was a different longing. . Her life was simply the form of it, the prowing and prepering form of love. I

$$
\text { It was all, for Mary, a new confusion }
$$

added to confusion: too immediate it had come, this summer in the hotel, upon the confusion of inant. Her inward life wes chaos, and as she struggled. - mutely, unconsciously. . . to bring it into order, always ner elements poured in, of choos.

To outsiders, Hary was industrious, timid, silent. "But within the rising choos of her life rose lary's need to master it: to find a solid center that she might call her life." Mary never lost her belief in Christ; she never found peoce until she found deep, abiding love, but she wos not content with less then whet fulfilled her. Grandmother otis, blind and dyino, told in a beautiful way the difference between the two girls:

"Last night, I heard the whippoorwill. There's \& Yankee bird. It cuts straight through 1. The Bridegroom cometh, p. 119 . 2. Ibid., p. 433 . 
the night. My grandfather told me of the nightingale in England. There's a different bird! It swellowed the night, it sang with the night in its throat. A hoavy burden. It couldn't cut through the night, bearing that heavy burden. Whippoorwills could fly across the ocean."

"You're not a Yankee, lertha. . You're a nightingale and the night is in you. "Teors were in the eves of the old women. "You can't cross the sea, hesvy laden with night, dear Hartha. Happy irtha..."

"Martha, don't be afraid to die. You and your husband, you will die. Not alone... Her voice yet clear, but weaker: "Ann, you are alone. Hiary is your child. Mery. • - is... glone."

And now for the first time, Margaret otis turned aside, facing streight toward Hary. "You cut through the night." 1

The young girls discussed thus far hove conformed more or less to their training and envirpnment and have not strayed far from the conventional peth. They have been singularly free from such ultro-modern influences as cocktail hours, highball dotes, jozz sessions, and swing. Waldo Frank does not consider these problems in relation to his young girls until he presents lilie Taess in The Bridegroom Cometh.

Lilie had been reared in a quiet, cultured, refined Jewish home by her mother and brother. Willem tells Mary on our first introduction to Lilie that she has been acting as if she wanted to kick over the traces. She has been going with a loud, restless, modern bunch who flirt end look I. The Bridegroom Cometh, p.433. 
for thrills. Mary went with Lilie sometimes to places where she met her friends, and she found them a stronge 10t. The boys insisted that they loved nothing and no one, and the girls made no demands on the boys for affection or understanding. Each had something the other wanted it wes fair exchenge.

Mary was trying hard to be a woman; and it was woman thet these young people hed no use for. That was why the girls were bobbing their hair, banting the hips, developing and showing their legs. They were trying to be veriants of boy, a bit softer and smaller, with brossts permitted if they were not too large. It wos a world without women. And a world without the words by which Mary had been nurtured: good, evil, sin, God, duty. . Were not denied by these young people meny of them older than kery; they were not even conceived.

They knem a thousand times more than Mary; they had traveled, studied music, read the megezines and latest novels. But under the plumge they were wingless birds running a high temperature trying to fly. That's what mede them so dependent on the boys. The boys gove them a life, even if it was always followed by a flop. And they knew the flop wes coming: they did not even believe in the possibility of flying: 1

Mrs. Taess did not seem to be greetly worried about Lilie. She morried \& lot about her esting the right food, wearing the right clothes, having g good time, end eventually morrying a man in their set with noney and social position. But what Mary colled her life-- her soul and her salvation -- worried Mrs. Teess not at all.

I. Dark Mother, p. 337 . 
Then there comes the day when lilie told Mary she hod been to the apartment of a man and had permittod some intimacies, but for Mery not to worry - - she knew how far to let him go and when to make him stop. She said she did not even love the man - - it was just for a thrill. Once, Mary want to a speakeasy with Lilie, and she saw the women there "sheathed.. - the women in their furs were ruthless-hard as if they knew where they were going and were not sure of arriving." 1 Mary took Lilie home with her os soon as she could get \&.way.

Mary sensed the girl's body sing with tension: it was a lovely body, it was hungry,
it was seeking its own perce. 2 She tells Mary thet no one is any good, that most people are scared; thot 1 ife is rotten, and "to hell with it." Her life is mapped out, enyhow. She must morry some rich Jew with o good family name, whether she loves him or not, for love doesn't make any difference. Wre see her very much in love with a South American soon, but she will not marry him. She will come very, very close to him and enjoy him, but when she marries, it will have to be someone of whom her mother approves. Just such a girl is Mathilde Crane in Summer Never Ends. It is the same wild, thrill-seeking set of young folks, the same irresponsibility, the same selfish yearning

1. The Bridegroom Cometh, p. 339 .

2. Ibid., 
for pleasures. Ler father admits that they have not taught Mathilde the right velues in life. Dagney Petersen, the main character in the same book, hes been discussed thoroughly in the chepter on $s e x$, but I wish to point out the differences and the similarities in her, Lilie, and Mathilde.

Dagney did not move in the seme social circle, and, therefore, the loose, idle crowd is not her companions. Dagney works for her living and has had a hard struggle. There is a seriousness and a purpose to her life that these young people lack. Dagney, however, does not believe in God; she spends no time in preparing her soul and her inner Iife for better, finer living. She is hard and uncompromising; whether she hos sexual relations with crane or with

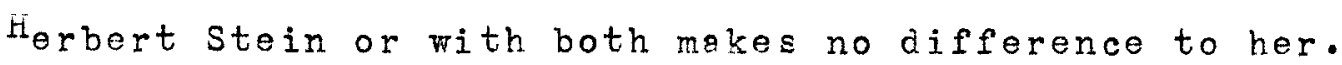
She has no conscientious scruples against lying or living - lie if it will serve her purpose. There are no moral principles to form a foundetion for a good life. That she Will move selfishly and coldly on her way is on essured fact. Ferbert compleins that she doesn't feel deeply about anything, and she admits to crone that it doesn't make a great deal of difference whether or not she loves the man she marries, end she doesn't expect to respect him.

In Dawn in Russig, Traldo Fronk reports a conversetion which he had with a young girl who worked in a kitchen when 
she was not studing medicine. She was built like a peasant mother, and her body was herd like the springtime. She

osked questions.

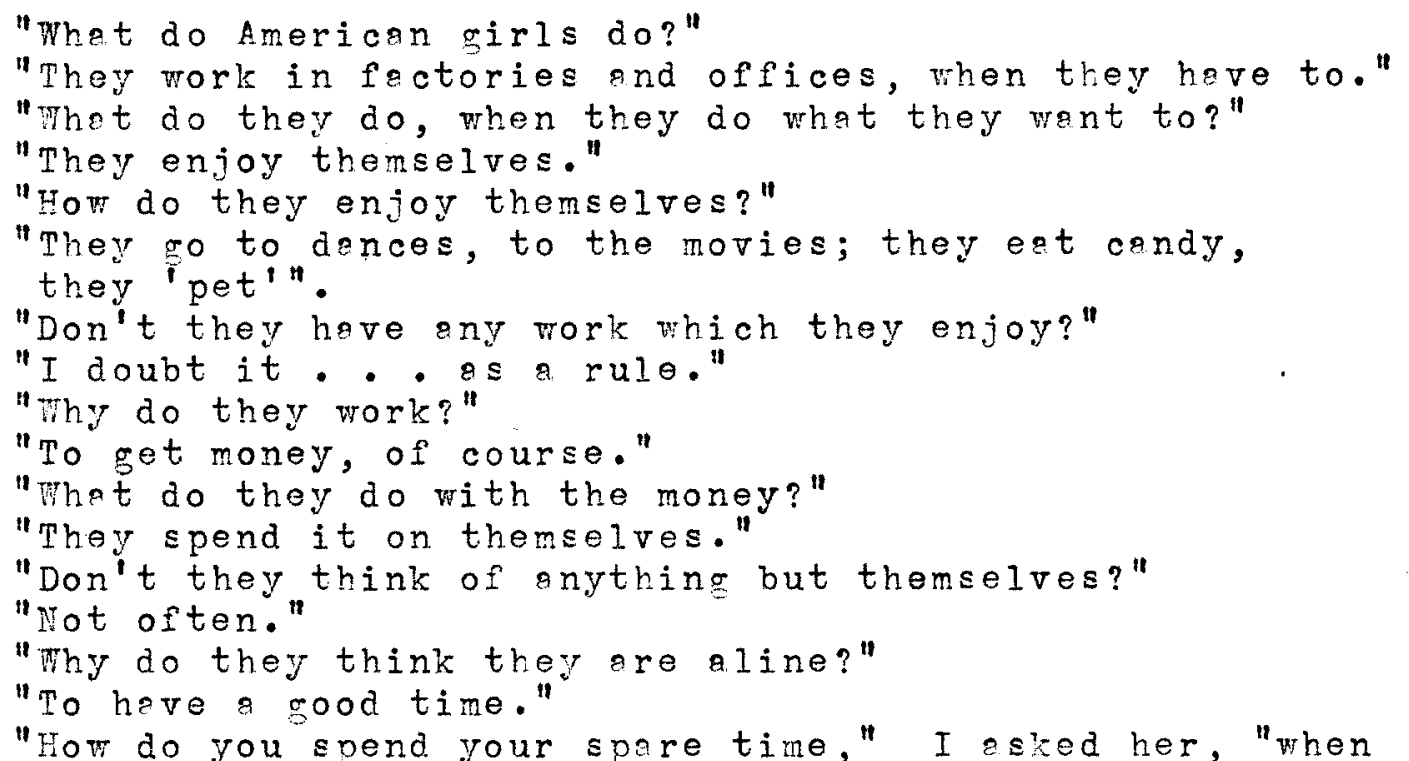
"How do you spend your spare time," I asked her, "when you are not studying medicine or working in the kitchen? Surely, then, you enjoy yourself?"

"Of course." And she expleined how she spent it: she had a cless of illiterote mothers, every night. Also she had her Party meetings (she ras a Youn Communist). And there wes a lot of reading to be done, elong nonprofessional lines. 1

These young girls, potently, gre the key to Mr. Frank's treatment of mothers, married women, ond sex. In his presentation of the younger generation of women one can see why he has no integrated mothers who find fulfillment in motherhood. Let us sum up the charecteristics of these girls end see just how they fit into his picture of women in general.

1. Their mothers have given to these young girls the

1. Frank, Waldo, Dgwn in Russia, pp. 19l-2. 
false standards of life. Lois, Lilie, Marcia, wathilde, and clarice have been reared to marry a man of financial value ond of good social standing. They have been taught just how to evaluate all other things in relation to this one importent item. Time end effort ond thought and worry have been spent on their clothes, their looks, their ections, end the kind of friends they heve, but no time has been consumed in worrying about their souls and heorts. Ho effort has been spent in teaching them to live more fully and deeply. They cennot, therefore, bring to merriege and motherhood the richness and depths which is required if either or both ere to bring fulfillment.

2. They heve learned early to suppress their feelings until they hove become creetures of shallowness and emptiness, incepeble of genuine emotion. Lois, clarice, Dagney, Rhoda, end the several girls ve studied in the chepter on sex, ere emotionally bankrupt. We have seen how futile trey ere in sexul experiences. One can understand that women of such cold, frozen, ond shallow feelings could never stir their husbends to any depths, and their marrieges, therefore, ere as deroid of satisfaction as they ere of emotion. Nothing brings to my mind a picture of complete frustration more than these vords: emotionless mothers. There ere such women, but it is an insult to the word mother. Motherhood is founded and based on the full heart and the sublimeted emotions coming from the heart. 
3. The hardness and selfishness which one sees in these modern girls likewise do not make for happy merriages or good nothers. Women's wills must be subordinoted to that of her husband and children so thet, blended, they form one, if the home is to be a happy one:

4. They deny God; they leugh et whet weldo Frank terms the "Greet Tradition"; religion has no part in their lives. They, os Helen Deindre Harkand did, will discover thet merriege is too grent a stroin and that motherhood cannot be borne unless one has God to rely upon, to believe in. To build home that is Whole and to ros childron that ere vorthwhile, one must have g genuine belief in God and the teachings of christ.

5. As hary Teess observed in lilie and her crowd and as is manifested by Degney Petersen towara Herbert, girls demand nothing of $\varepsilon$ man in a moral sense, chiefly becouse they expect to give nothing in the sense of moral fair play. These modern romen want money, luxuries, security, sociel positions; the men, as Nortimer Crene ond Luke Corns, sell their souls to get it, and the women hove no respect for them for doing so.

6. Love hes no place in their lives. They cannot lore deeply beceuse of the ressons given gbove. Wr. Frank says that to live is to love. The conclusions are obvious. 7. Phose who have depth and cheracter and ere copable of genuine understanding, such os Adelaide ond Cornelia, 
do not appeal to the men.

8. Wery, the mystic, the seeker, the one who becomes, through endless segrchings, geal person, would make a wonderful mother end en excellent wife for the man whom she could respect and love. She pill not bring children into the world in an irresponsible manner, into a home devoid of love, and, for thet reason, remeins childless.

3. The young poople whom he portrays in The Bridegroom Cometh end in Summer Never Ends, such es Lilie ond her crowd, Mathilde and Somerset Crane, and Dagney Petersen, Iive for sexuel thrills end experiences. The suthor does not condemn this practice of loose sexual reletionstips, but he does say, in Virgin Spein:

process nurtured et the expense of the maternal

10. Finelly, the author says:

Wy own experience is, thet Americans of the so-celled young inteliectual clesses are the least viteliy concerned, the least spiritue $11 y$ quickened of eny I have encountered. Litereture is less to them than a sport (which hes its rules of excellence): it is a liquor in which the ingredients, as with bootleg whiskey, are of no importence. Everything, good and bad, is poured into the punch-bowl; the point is, to refili it often and quickly.

Such characteristics which have been transmitted to these girls by their perents and friends are breeders of

1. Frank, Waldo, $\frac{\text { Virgin }}{\text { Pearce }} \frac{\text { Spain }}{1942}$, Revised Edition), p. 247 . 2. Frank, Waldo, ke-Discovery of America, p. 228 . 
chaos. They will poison husbands and children in turn with it. Thet is why romen ore restless, dissatisfied, and unhappy. There is no foundation of stability, no interest in work, none in humanity. Two conversations on the part of fictionel cheracters indicate a consciousness of the problem of modern women.

One conversation is between Willem and Doris, when he asks her for advice about making his merrige a success and winning Vary. Doris says:

There's a new race of women in this country. . . The new race of women in America mesns just thet: the emergence of mind. So they must reject the foods of the vegetebles - - the simple sun and vater women used to get along with. 1

". . Tomen have been swung off their base, here in America. Wuch more than in meny countries of Europe, where men love women and therefore let them be themselves - - on low terms, I admit. Here, men don't care for women; women have lost that sense of themselves that comes from being really loved by man. So they've gone over into a man's world. Thought like men. . "

"And $-?$ "

"It doesn't work! We've got to have'minds of our own. And that means starting with our bodies."

"A good Voman's mind's got to begin by rejecting all the ready-made, man-made mindfoods. Got to begin by discovering her body." 2

The other. is the opinion of Dolg, the Russien Communist, given et a party one night when Mary is present. Dolg says that some women here in America remind him of shakespeare. When pressed for an explanation, he says:

1. Frank, Waldo, The Bridegroom Cometh, p. 380 . 2. Frank, op.cit., pp. 380-381. 
"It's the discreponcy in his plays botween the fresh loveliness of word and charocter on the one hand, and the heavy action... It's the out-of-placeness. 1

"The split in Shakespeare's plays, between the temperament of the characters and their action: thet is also England.

"American life sometimes seems to me the fulfillment of England's curse.. . this split. liere are women deep-seeing, strong, lovely as Shakespeare's song: and as sad! Homeless women. Trying to ect as ports of an elien, man-node mechine. I refer to capitalism." 2

"I knew," laughed Peter, "it'à all end in an attack on our social system."

Dolg said quietly: "I can understand American men of certain kinds defending capitalism. They have a good time till they get licked. But all women have a bad time." 3

Thet the men are in e lerge measure responsible for this state of affairs has already been shown. But the solution is left to the women. Like the whippoorvill which cuts through the night, they will have to do that finding and that traveling . . alone.

1. Frank, op.oit., p. 392 .

2. Ibid. $=\mathrm{p} \cdot 394$.

3. Ibid., p. 395 . 
CONGLUS ION 
CONCLUSION

\section{The Problem.}

"The essestial cause of the tragedy of American woman is that American men do not like women. They use them, of course: as motrers, nurses, and sexual objects are used by immature men, but they do not like what is essentially woman. Women, realizing this, have denatured themselves, in their desperate need to please -- ond American women are an unhappy lot even as Americen men are en unrealized, unvital, unvirile tribe. This is the grestest menace to the promise of Americen culture." 1

Succinctly and frenkly expressed, that is Waldo Frank's view of modern woman. Because she hos long since realized that men do have this antagonism toward her, woman hes gone after the men, going outside herself to win from herself what men had always given her. She has gone into the world of men in an effort to become like them. She has sought to dominate in the home and in the world of finance and business where she works with the men and for them; she has metched her will with his, determinedly and doggedly. She is learning today that such a course is sterile and suicidal, ending almeys in frustration. Knoving intuitively that all such efforts would end in frustration, she has become, 
dissatisfied, and filled with longings for an infinitely better life then that which is hers. This is woman today in Americe as Waldo Frenk sees her.

\section{The Source.}

The source of this problem is tro-fold. In the first plece, man, as an instrument of power, not of love, worships power and fills his heart with a love for the machine. As such, he is the generstor of chaos. Into this field, in a desperate effort to achieve fulfillment, woman follored man. In the second place, isolationism has played its port in the problen. The very chaos, generated by power, has thwerted and twisted the neturel love in our hearts and has isoleted the women from the men, preventing them from becoming integreted into groups of other women and into some field of work. They have become homeless creatures, alone and lonely, in a world where men are incapoble of giving them love because they themselves are loveless.

\section{The solution.}

The solution of this problem, as given by Waldo Frank, lies in the development of integrel persons realizing the divine in the humen, with sense of the whole, personelly at work upon a universal mission instead of petty individualistic aspirations.

4. The Fiction.

The presentetion of this view in fictionel form shows 
a certain development in the guthor's outlook. In his earlier novels, the focus was on sex; later, it changed to marriage; and, then, lastly, to an emphasis on womanhood and her universal problems. This shifting focus was based, however, on a fundamental outlook that was formulated early in his coreer and respresents an unfolding of beliefs thet he has had from the beginning. It is as if he embodied in his earlier fiction those concepts which were nearest to him personally at the time, but as he himself opened to the greater world, other ideas, which he had nurtured ell along, exponded until they embreced ell thet hod been expressed before, taking unto themselves at the same time the new and wider fields of survey until sex and merriage and motherhood unite under the all-embracing term - mononhood.

\section{Limitations.}

In giving us this fictional view of modern woman, he presents her elmost exclusively from a men's point of viev. This, and the fact thot his portrayals are those of the witer from the big city, are his only limitations.

\section{Polerity.}

In his trentment, he gives us romen in terms of tro opposite poles: frustration and the striving toward integration. Many minor factors help to bring about ultimete frustration, but over all there is the major 
cause - the inebility of the individual to become a person. Those who heve refused to accept frustration as their portion are the ones who, through universal love end anincorporation of the Divine in their lives, heve been able to integrate themselves in such a way as to become persons.

\section{Factors Determining This View.}

This view is to be accounted for by the position of women in the trentieth century. Their economic incependence, their sexual freedom, end their forsaking those very feininine traits so inherently theirs in order to become like men, have brought about o restlessness and an inner diseatisfaction which heve resulted in psychologicel frustration.

Another contributing fector to the presentation of vomen in this manner is la do Frank's own background and experience and his intellectual outlook. The fact that he is a cosmopolite and a rorld troveler accounts for his toking sexual freedom and prostitution for granted in a way that a regionalistic writer would never do. such a broad, tolerant outlook enebles him to treat 811 notters pertaining to sex in a sensate manner, free from all inhibitions. His intellectual outlook is one of monistic materialism enỏ of a mysticel optimism. He believes that God is in man. He once made this statement:

God is in every man - every self. That I know with an immediate certainty that has no equal. And I do try, in my poor bungling ray, 
to realize, $\theta s$ I talk with my brothers and

my sisters, end as I look out on the historic

scene, thet GOD is in them all. It is a.

frightful peradox; and the sole threshold

to truth.

$\mathrm{He}$ is also optimistic obout the future of America. "I may

as well say before I strike the deep notes of danger thet

I would not strike them, did I not have hope as well es

love for the American destiny", ${ }^{1}$ is one of his early

remerks in Chart for Rough Weter.

He has also said:

For we hove seen thot America is capturable, that it needs to be captured: nor would such leodership be a tonelity strange to our land with its great mystic tradition and with the ottuning spirit of its aboriginel cultures. It would be fulfillment.

In a symphony, eoch note rises ond speaks end disappers forever. Lany notes are grouped to meke melodies and themes; are interwoven to fill chords; and these, too, ticie and fall. All the innumeroble notes lift their instant voices, and pass, end only the symphony remeins. such rould be our nation; seve thet its creator would not be "outside" the music. He woulc be the individual note, itself - the group of notes, building the structure of the Whole by knowing the Whole end by living it, personelly, in its
severel perts.

8. Evaluation.

The vrlue of Waldo Frank's views lies chiefly in tro accomplishments. He has worked out his own philosophy of life bosed on wide experience and deep thought. It is a philosophy thet hes been evolved through yesrs of living

1. Chart for Rough Water, pp. $22-23$.

2. ke-Discovery of America, pp. 258-20. 
with many people of several continents and observing closely how they live; of coming in contact with the intellectuals and the leaders of verious countries and learning their views; and of studying the fundrmental concepts of the writers of all gges. This philosophy of his permeetes his fiction, giving body end substonce to his characterizations.

He shows keen insight into the problems of modern women and the difficulties they encounter in attempting to edjust themelves to modern society in a way thet will bring lesting fulfillment. One does not find in his fiction that personal irritation against momen that sharacterizes the appoach of so many present-day men writers. He himself hes great love for what woman actualiy is, for her very nature, ond he feels thet he understands our American women. I have found no women writers whose presentetion of the trentieth century women is es comprehensive nor whose philosophy is os acceptably sound as that of Mr. Fronk. Many women writers have deslt with only one phase of the problem, and others heve handed the changing status of women superficially with no attempt being made to point the woy out or to solve eny of the problems confronting them.

Maldo Frank not only makes an honest endeavor in his fiction to present women, but he tries to analyze carefully a.l contributing factors that have mode her what she is. Instead of portraying her as a necessary evil to be endured 
by men, and dismissing her as such, Waldo Frank gives us her background, her training, the influence of husbands and friends, and the social adustments she hos been forced to make. Then, she stands forth, the woman whom birth, environment, education, end American culture hove produced. She is the twentieth century Woman:

kr. Frank remarked recently that:

Will is the curse of Americen romen. An artist knows that his own will must be crucified to become e pert of a greater freedom. He does this willingly, subrerging himself in order to produce an integrated piece of work. Women todey went to hold on to their will: they will not permit this personal will to become crucified in order to become a part of a greater Whole. They cling tenaciously and stubbornly to their own individual wills, but they will have to learn that they, too, will heve to submerge themselves if they are to become a part of that greater freedom, if they are to produce an integrated piece of work. 1 


\section{BIBLIOGRAPHY}
Beach, Joseph, The Trentieth Century Novel. New York: The century co., 1932 .
Frank, Waldo, Unwelcome Man. Boston: Little, Brown and Frank, Waldo, The Dark Nother. New York: Boni and Liveright, 1920 .
Frank, Weldo, City Block. Derien, Conn: Waldo Prank,
Frank, Waldo, $\frac{\text { Summer }}{\text { and Pearerer }} \frac{\text { Ends. New York: Duel, Sloen }}{1941 .}$
Frank, Waldo, The Briderroom Cometh. New York: Doubleday

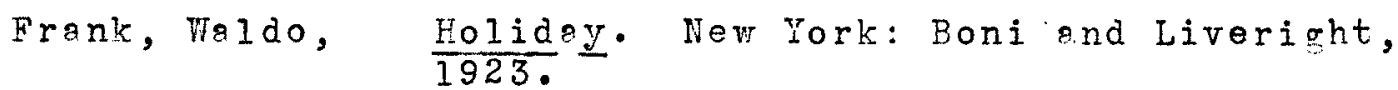

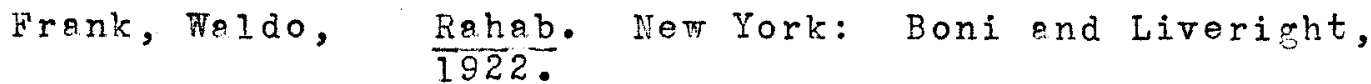
Frank, Waldo, The Death and Birth of David Markand. New York: Charles Scribner's Sons, 1934.
Frank, Waldo, New Year's Eve. Play. New York: Charles Scribner's Sons, 1929.

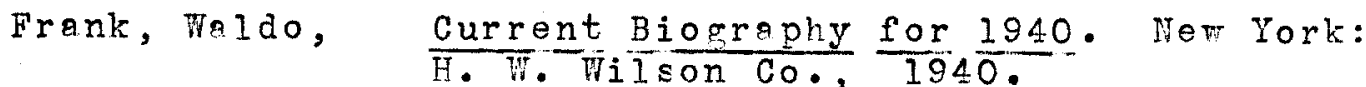

